\title{
Enhanced Component Performance Study: Emergency Diesel Generators 1998-2018
}

Zhegang Ma

September 2019

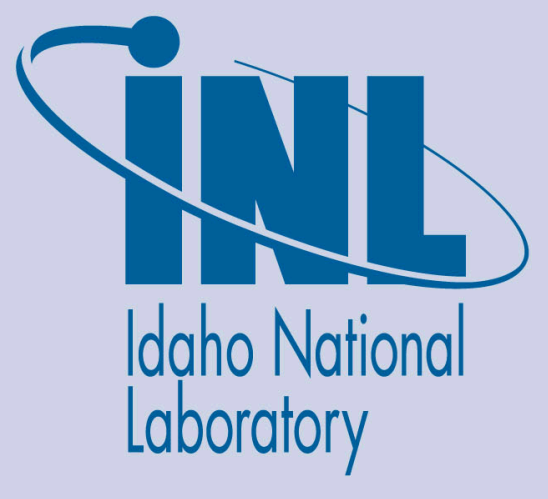

The INL is a U.S. Department of Energy National Laboratory operated by Battelle Energy Alliance 
NOTICE

This information was prepared as an account of work sponsored by an agency of the U.S. Government. Neither the U.S. Government nor any agency thereof, nor any of their employees, makes any warranty, express or implied, or assumes any legal liability or responsibility for any third party's use, or the results of such use, of any information, apparatus, product, or process disclosed herein, or represents that its use by such third party would not infringe privately owned rights. The views expressed herein are not necessarily those of the U.S. Nuclear Regulatory Commission. 


\title{
Enhanced Component Performance Study: Emergency Diesel Generators 1998-2018
}

\author{
Zhegang Ma
}

Update Completed September 2019

\author{
Idaho National Laboratory \\ Risk Assessment and Management Services Department \\ Idaho Falls, Idaho 83415 \\ http://www.inl.gov
}

Prepared for the Division of Risk Assessment Office of Nuclear Regulatory Research

U.S. Nuclear Regulatory Commission

NRC Agreement Number NRC-HQ-60-14-D-0018 



\begin{abstract}
This report presents an enhanced performance evaluation of emergency diesel generators (EDGs) at U.S. commercial nuclear power plants. This report evaluates component performance over time using (1) Institute of Nuclear Power Operations (INPO) Consolidated Events Database (ICES) data from 1998 through 2018 and (2) maintenance unavailability (UA) performance data from Mitigating Systems Performance Index (MSPI) Basis Document data from 2002 through 2018. The objective is to show estimates of current failure probabilities and rates related to EDGs, trend these data on an annual basis, determine if the current data are consistent with the probability distributions currently recommended for use in NRC probabilistic risk assessments, show how the reliability data differ for different EDG manufacturers and for EDGs with different ratings; and summarize the subcomponents, causes, detection methods, and recovery associated with each EDG failure mode. Engineering analyses were performed with respect to time period and failure mode without regard to the actual number of EDGs at each plant. The factors analyzed are: subcomponent, failure cause, detection method, recovery, manufacturer, and EDG rating.

A statistically significant increasing trend was identified in the frequency of FTLR demands for emergency power system (EPS) and high pressure core spray (HPCS) EDGs and a statistically significant decreasing trend was identified in the frequency of failure to run $>1 \mathrm{H}$ hours for EPS and HPCS EDGs.
\end{abstract}


Enhanced Component Performance Study 


\section{CONTENTS}

ABSTRACT .iii

ACRONYMS ix

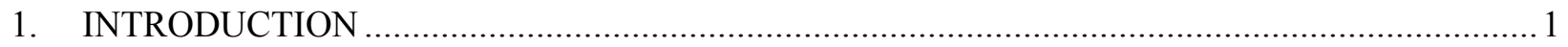

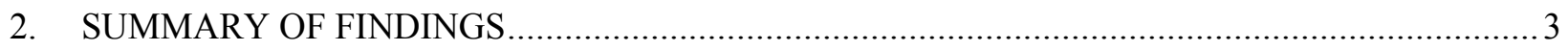

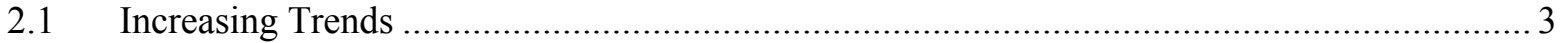

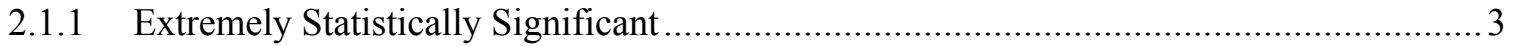

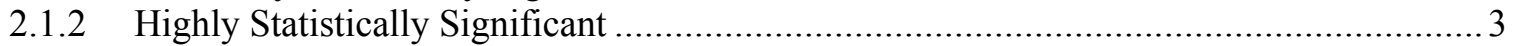

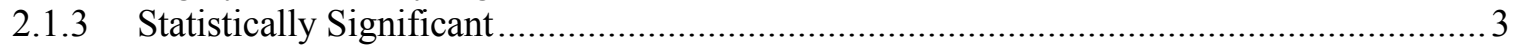

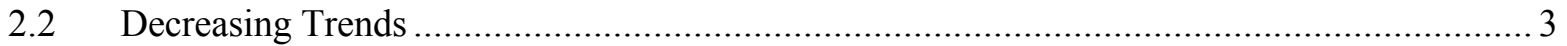

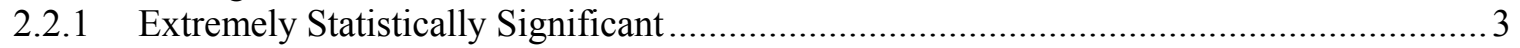

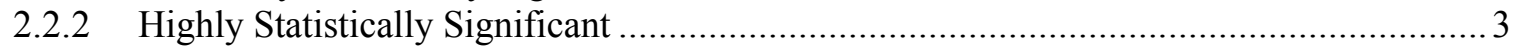

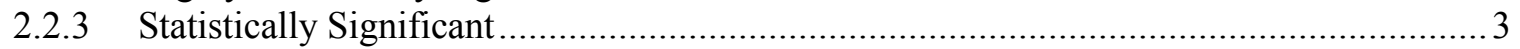

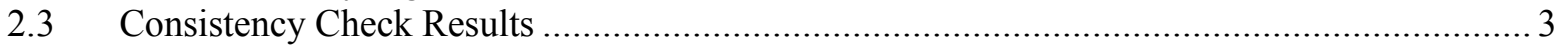

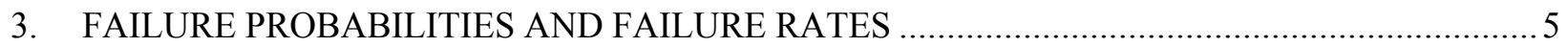

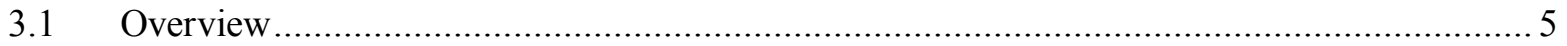

3.2 EDG Failure Probability and Failure Rate Trends ...................................................... 5

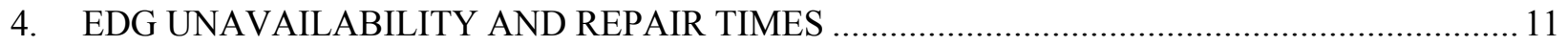

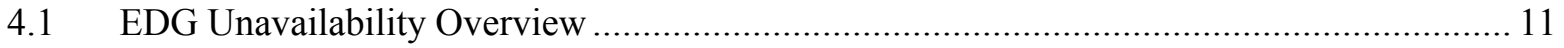

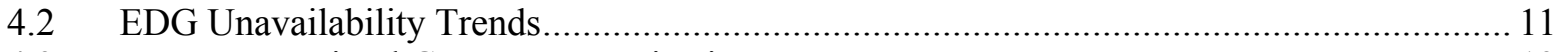

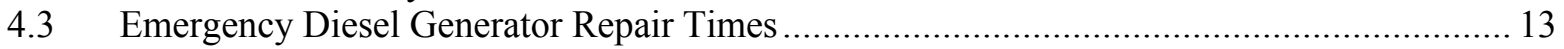

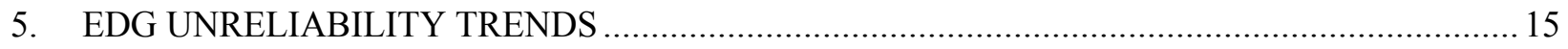

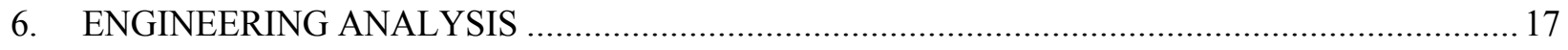

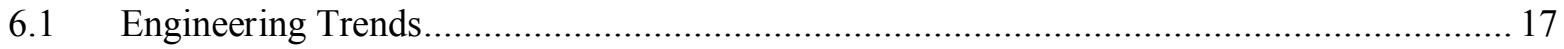

6.2 Comparison of ICES EPS EDG Unplanned Demand Results with Industry Results ............ 21

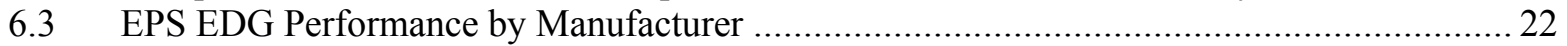

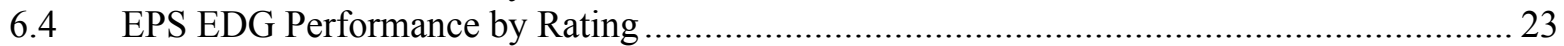

6.5 EPS EDG Engineering Analysis by Failure Modes....................................................... 23

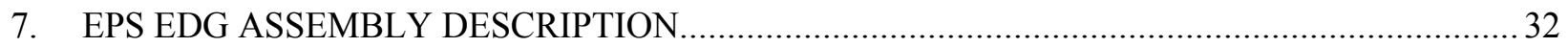

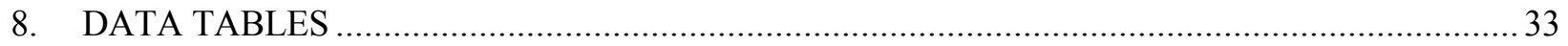

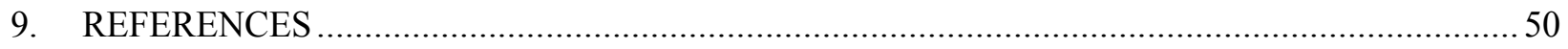




\section{FIGURES}

Figure 1. Failure probability estimate trend for EPS EDG FTS .................................................. 8

Figure 2. Failure probability estimate trend for EPS EDG FTLR ................................................. 8

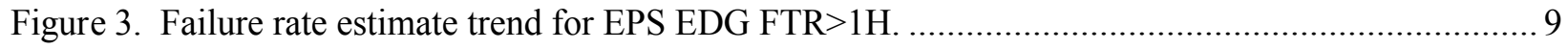

Figure 4. Failure probability estimate trend for HPCS EDG FTS................................................. 9

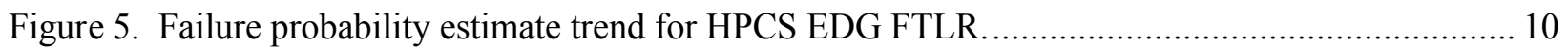

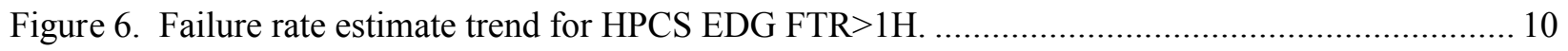

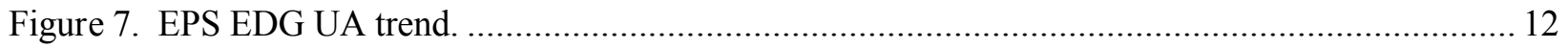

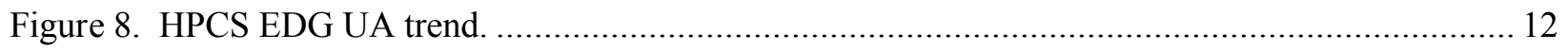

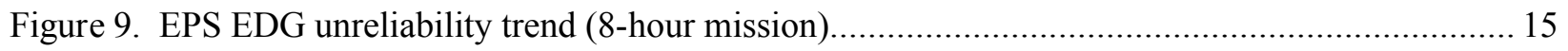

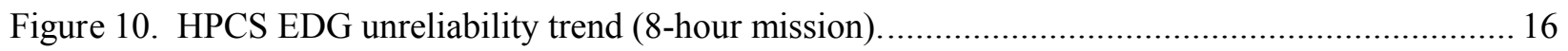

Figure 11. Frequency of start demands (demands per reactor year) for EPS and HPCS EDGs............... 18

Figure 12. Frequency of FTLR demands (demands per reactor year) trend for EPS and HPCS

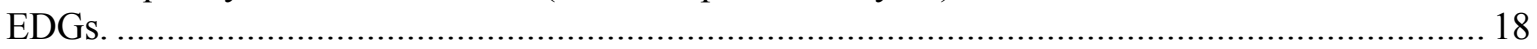

Figure 13. Frequency of run $>1 \mathrm{H}$ hours (hours per reactor year) trend for EPS and HPCS EDGs.......... 19

Figure 14. Frequency of FTS events (events per reactor year) trend for EPS and HPCS EDGs. ............. 19

Figure 15. Frequency of FTLR events (events per reactor year) trend for EPS and HPCS EDGs........... 20

Figure 16. Frequency of FTR $>1 \mathrm{H}$ events (events per reactor year) trend for EPS and HPCS EDGs. 20

Figure 17. EPS EDG failure breakdown by sub component and failure mode ..................................26

Figure 18. EPS EDG breakdown by cause group and failure mode ............................................... 27

Figure 19. EPS EDG component failure distribution failure mode and method of detection.................. 28

Figure 20. EPS EDG component failure distribution by failure mode and recovery determination ......... 29

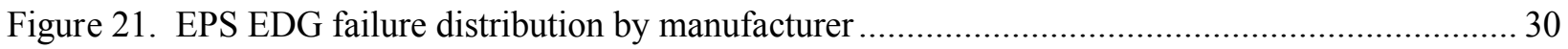

Figure 22. EPS EDG component failure modes by EPS EDG rating .............................................. 31 


\section{TABLES}

Table 1. EDG systems. 5

Table 2. Industry-wide distributions of $\mathrm{p}$ (failure probability) and $\lambda$ (hourly rate) for EPS EDGs, from the 2015 Update.

Table 3. Industry-wide distributions of $p$ (failure probability) and $\lambda$ (hourly rate) for HPCS EDGs. .5

Table 4. Industry-average unavailability estimates for EPS EDGs. 11

Table 5. Weibull curve fit parameters. 13

Table 6. Probability of exceeding selected EDG repair times (2009-2018). 14

Table 7. Summary of EDG failure counts for the FTS failure mode over time by system. 21

Table 8. Summary of EDG failure counts for the FTLR failure mode over time by system. 21

Table 9. Summary of EDG failure counts for the FTR $>1 \mathrm{H}$ failure mode over time by system. 21

Table 10. EPS EDG unplanned demand performance comparison with industry-average performance from ICES data.

Table 11. EPS EDG manufacturer performance compared with industry-average performanceFTS, FTLR, and FTR $>1 \mathrm{H}$ combined.

Table 12. EPS EDG rating performance compared with industry-average performance-FTS, FTLR, and FTR $>1 \mathrm{H}$ combined.

Table 13. Component failure cause groups. 24

Table 14. EPS EDG manufacturer population and total failure count 30

Table 15. EPS EDG population by rating. 31

Table 16. Plot data for Figure 1, failure probability estimate trend for EPS EDG FTS 34

Table 17. Plot data for Figure 2, failure probability estimate trend for EPS EDG FTLR 35

Table 18. Plot data for Figure 3, failure rate estimate trend for EPS EDG FTR $>1$ H ......................... 36

Table 19. Plot data for Figure 4, failure probability estimate trend for HPCS EDG FTS ...................... 37

Table 20. Plot data for Figure 5, failure probability estimate trend for HPCS EDG FTLR .................... 38

Table 21. Plot data for Figure 6, failure rate estimate trend for HPCS EDG FTR $>1$ H ......................... 39

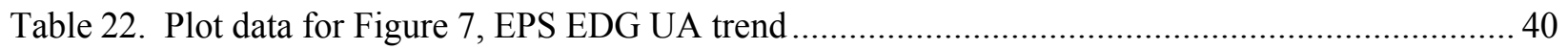

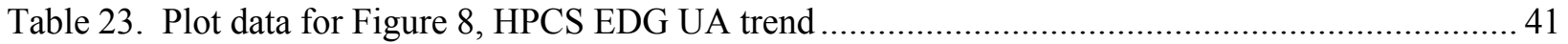


Table 24. Plot data for Figure 9, EPS EDG unreliability trend (8-hour mission)

Table 25. Plot data for Figure 10, HPCS EDG unreliability trend (8-hour mission)

Table 26. Plot data for Figure 11, frequency of start demands (demands per reactor year) trend for EPS and HPCS EDGs

Table 27. Plot data for Figure 12, frequency of FTLR demands (demands per reactor year) trend for EPS and HPCS EDGs ..

Table 28. Plot data for Figure 13, frequency of run $>1 \mathrm{H}$ hours (hours per reactor year) trend for EPS and HPCS EDG

Table 29. Plot data for Figure 14, frequency of FTS events (events per reactor year) trend for EPS and HPCS EDGs.

Table 30. Plot data for Figure 15, frequency of FTLR events (events per reactor year) trend for EPS and HPCS EDGs.

Table 31. Plot data for Figure 16, frequency of FTR $>1 \mathrm{H}$ events (events per reactor year) trend for EPS and HPCS EDGs 


\section{ACRONYMS}

\begin{tabular}{|c|c|}
\hline $\mathrm{AOV}$ & air-operated valve \\
\hline $\begin{array}{l}\text { CNID } \\
\text { CY }\end{array}$ & $\begin{array}{l}\text { constrained non-informative prior distribution } \\
\text { calendar year }\end{array}$ \\
\hline $\begin{array}{l}\text { EDG } \\
\text { EPIX } \\
\text { EPS } \\
\text { ESF }\end{array}$ & $\begin{array}{l}\text { emergency diesel generator } \\
\text { Equipment Performance and Information Exchange } \\
\text { emergency power supply } \\
\text { engineered safety feature }\end{array}$ \\
\hline $\begin{array}{l}\text { FTLR } \\
\text { FTR }>1 \mathrm{H} \\
\text { FTS } \\
\text { FY }\end{array}$ & $\begin{array}{l}\text { failure to load and run } \\
\text { failure to run }>1 \text { hour } \\
\text { failure to start } \\
\text { fiscal year }\end{array}$ \\
\hline HPCS & high-pressure core spray \\
\hline $\begin{array}{l}\text { ICES } \\
\text { INL } \\
\text { INPO } \\
\text { IRIS }\end{array}$ & $\begin{array}{l}\text { INPO Consolidated Events Database } \\
\text { Idaho National laboratory } \\
\text { Institute of Nuclear Power Operations } \\
\text { Industry Reporting and Information System }\end{array}$ \\
\hline $\begin{array}{l}\text { MDP } \\
\text { MOV } \\
\text { MSPI }\end{array}$ & $\begin{array}{l}\text { motor-driven pump } \\
\text { motor-operated valve } \\
\text { Mitigating Systems Performance Index }\end{array}$ \\
\hline $\begin{array}{l}\text { NPRDS } \\
\text { NRC }\end{array}$ & $\begin{array}{l}\text { Nuclear Plant Reliability Data System } \\
\text { Nuclear Regulatory Commission }\end{array}$ \\
\hline OLS & ordinary least squares \\
\hline PRA & probabilistic risk assessment \\
\hline TDP & turbine-driven pump \\
\hline JA & unavailability \\
\hline
\end{tabular}




\section{Enhanced Component Performance Study: Emergency Diesel Generators 1998-2018}

\section{INTRODUCTION}

This report presents a performance evaluation of emergency diesel generators (EDGs) at U.S. commercial nuclear power plants from 1998 through 2018. The objective is to show estimates of current failure probabilities and rates related to EDGs, trend these data on an annual basis, determine if the current data are consistent with the probability distributions currently recommended for use in NRC probabilistic risk assessments, show how the reliability data differ for different EDG manufacturers and for EDGs with different ratings; and summarize the subcomponents, causes, detection methods, and recovery associated with each EDG failure mode. This year's update continues with the three changes implemented in the 2016 update that are different from prior updates: (1) the update results are based on calendar year (CY) instead of the federal fiscal year (FY); (2) the failure events included in the update are "hard" failures, i.e., the p-values indicating the likelihood the component would have failed during a 24hour mission are 1.0. Previous updates (2015 and before) include lesser p-values indicating a degraded condition that probably would have caused failure during a 24-hour mission but were not quite hard failures at their outset. (3) The discussion of EDG repair times, which was previously included in the annual LOOP updates (see http://nrcoe.inl.gov/resultsdb/LOSP), is included in this report.

The enhanced component performance studies are conducted for the following component types: airoperated valves (AOVs), EDGs, motor-driven pumps (MDPs), motor-operated valves (MOVs), and turbine-driven pumps (TDPs). The EDG performance analysis was first conducted in 2007 with data from 1998 through 2006 [1] and then updated annually in a series of reports, with the last one being documented in INL/LTD-17-44204, Enhanced Component Performance Study: Emergency Diesel Generators 1998-2016 [2]. The Nuclear Regulatory Commission (NRC) Reactor Operational Experience Results and Databases web page provides the links to the historical and current results of component performance studies (http://nrcoe.inl.gov/resultsdb/CompPerf). An overview of the trending methods, glossary of terms, and abbreviations is documented in the paper Overview and Reference [3] that can also be found on that web page.

The data used in this study are based on the operating experience failure reports from Institute of Nuclear Power Operations (INPO) Consolidated Events Database (ICES) [4], formerly the Equipment Performance and Information Exchange Database (EPIX) and now upgraded again to IRIS, the Industry Reporting and Information System. Maintenance unavailability (UA) performance data came from the Reactor Oversight Process program's Mitigating Systems Performance Index (MSPI) program [5] and ICES. Previously, the study relied on operating experience obtained from licensee event reports, Nuclear Plant Reliability Data System (NPRDS), and ICES. The ICES database, now IRIS, (which includes the MSPI designated devices as a subset) has matured to the point where both component availability and reliability can be estimated with a high degree of accuracy. In addition, the population of data in current ICES database is much larger than the population available in the previous study.

The EDG failure modes considered are failure to start (FTS), failure to load and run (FTLR), and failure to run greater than 1-hour $(\mathrm{FTR}>1 \mathrm{H})$. Annual failure probabilities (failures per demand) are provided for FTS and FTLR events and annual failure rates (failures per run hour) are provided for FTR $>$ $1 \mathrm{H}$ events. EDG train maintenance unavailability probabilities are also considered. In addition to the presentation of the component failure mode data and the UA data, an 8-hour component total unreliability is calculated and trended. Each of the estimates is trended for the most recent 10 -year period. Yearly 
estimates have been provided for the entire study period. The results are reported separately for emergency power system (EPS) and high pressure core spray (HPCS) EDGs.

While this report provides an overview of operational data and evaluate component performance over time, it makes no attempt to estimate values for use in probabilistic risk assessments (PRAs). The 2015 Component Reliability Update [6], is an update to NUREG/CR-6928, Industry-Average Performance for Components and Initiating Events at U.S Commercial Nuclear Power Plants [7], and reports the TDP unreliability estimates for probabilistic risk assessments. Estimates from that report are included herein, for comparison. Those estimates are labelled "2015 Update" (or "Update 2015") in the associated tables and figures.

Section 2 of this report presents the summary of findings from the study, with particular interest in the existence of any statistically significant increasing or decreasing trends in component performances. Section 3 provides annual estimates of failure probabilities and rates related to EDGs as well as the trending of the estimates. Section 4 provides EDG train UA estimates and their trends (Sections 4.1 and 4.2), as well as the discussion of EDG repair times (Section 4.3). Section 5 estimates the annual total unreliability and the trends for EDG.

Section 6 presents various engineering analyses performed for EDG with respect to time period and failure modes. In Section 6.1, the same failures used in Section 3 are used to compute estimates of overall failure frequencies per plant reactor year (with EPS and HPCS EDG failures combined). Frequencies of demands per plant reactor year are also provided for each year, for each of the possible failure modes. As in Section 3, each of the estimates is trended for the most recent 10-year period. The frequencies show general industry performances and are not based on the number of EDGs at each plant.

In Sections 6.2 through 6.4, various subsets of the EDG data are compared with the distributions currently recommended for PRA use in the "2015 Update." First, the subset of failure events and demands from this report that occurred on unplanned demands (engineered safety feature actuations) is compared for consistency with the 2015 Update data. This evaluation provided a check on the ongoing use of the 2015 Update EDG data (which includes failures from possibly incomplete testing demands). In Section 6.3, data from each EDG manufacturer is compared. Finally, in Section 6.4, EDG failure groupings based on EDG ratings are compared.

Section 6.5 provides breakdowns of the failures for each failure mode for the two plant systems with EDGs. The analyses are based on the following factors: sub-component, failure cause, detection method, and recovery.

Section 7 provides additional information on the EDG assembly component boundaries and failure modes. Section 8 presents the plot data for various figures in previous sections. 


\section{SUMMARY OF FINDINGS}

The results of this study are summarized in this section. Of particular interest is the existence of any statistically significant ${ }^{\mathrm{a}}$ increasing trends.

\subsection{Increasing Trends}

\subsubsection{Extremely Statistically Significant}

- None.

\subsubsection{Highly Statistically Significant}

- None.

\subsubsection{Statistically Significant}

- A statistically significant increasing trend in the frequency of FTLR demands for EPS and HPCS EDGs was identified with a p-value of 0.0165 (see Figure 12). This is a new trend that was not observed in the 2016 EDG update study [2].

\subsection{Decreasing Trends}

\subsubsection{Extremely Statistically Significant}

- None.

\subsubsection{Highly Statistically Significant}

- None.

\subsubsection{Statistically Significant}

- A statistically significant decreasing trend in the frequency of run $>1 H$ hours for EPS and HPCS EDGs was identified with a p-value of 0.0198 (see Figure 13). This trend had also been observed in the 2016 EDG update study as being highly statistically significant.

\subsection{Consistency Check Results}

An ongoing concern in the nuclear risk assessment field is whether industry failure rate estimates that are largely derived from test data adequately predict component performance during unplanned (ESF) demands. Section 6.2 provides results of a consistency check that compare industry failure estimates obtained via simulation test on parameters from the 2015 Update against operational failure counts obtained from actual EDG performance with ESF demands. These consistency checks show that the FTS, FTLR, and FTR failure observations in the non-test, operational ESF demand data lie within their corresponding industry-average failure estimate distributions, provided in the 2015 Update (Table 2), that were based on both test and non-test operational ESF demands.

\footnotetext{
a. Statistically significant is defined in terms of the 'p-value.' A p-value is a probability indicating whether to accept or reject the null hypothesis that there is no trend in the data. P-values of less than or equal to 0.05 indicate that we are $95 \%$ confident that there is a trend in the data (reject the null hypothesis of no trend.) By convention, we use the "Michelin Guide" scale: p-value $<0.05$ (statistically significant), p-value $<0.01$ (highly statistically significant); $p$ value $<0.001$ (extremely statistically significant).
} 
Section 6.3 provides the results of consistency checks by EDG manufacturer. Two manufacturer's ESF EPS EDG failure counts lie in the upper $95 \%$ of the uncertainty range of the industry-average estimate. However, these manufacturers have very few EPS EDGs, and so the data are limited. The remaining manufacturers' failure counts lie within the 5\% to $95 \%$ interval of the industry-average estimate uncertainty band.

Section 6.4 shows the results of the consistency check by EDG load rating. The failure counts by rating all lie within the $5 \%$ to $95 \%$ interval of the industry-average estimate uncertainty band. 


\section{FAILURE PROBABILITIES AND FAILURE RATES}

\subsection{Overview}

The failure probabilities and failure rates of EDGs have been calculated from the operating experience for FTS, FTLR, and FTR $>1 \mathrm{H}$. The EDG data set obtained from ICES includes EDGs in the systems listed in Table 1. Table 2 shows failure probability and failure rate estimates for the EPS EDG from Reference [6], or the 2015 Update. Table 3 shows the failure probability and failure rate estimates for the HPCS EDG. The HPCS EDG failure probability was not fully analyzed in [6] and is presented here based on the current ICES data that has been reviewed at Idaho National Laboratory (INL).

Table 1. EDG systems.

\begin{tabular}{llc}
\hline System & \multicolumn{1}{c}{ Description } & EDG Count \\
\hline EPS & Emergency power supply & 232 \\
HPCS & High pressure core spray & 8 \\
& Total & $\mathbf{2 4 0}$ \\
\hline
\end{tabular}

The EDGs do not operate all the time. They are standby-components required to operate when called upon, both when the reactor is critical and during shutdown periods. The demands and run hours are reported on a quarterly or semi-annual basis through the MSPI program. All demand types are considered - testing, non-testing, and those ESF demands that require the EDG to mitigate a bus undervoltage condition.

Table 2. 2015 Update industry-wide distributions of $p$ (failure probability) and $\lambda$ (hourly rate) for EPS EDG.

\begin{tabular}{|c|c|c|c|c|c|c|c|}
\hline \multirow{2}{*}{$\begin{array}{c}\text { Failure } \\
\text { Mode }\end{array}$} & \multirow[b]{2}{*}{$5 \%$} & \multirow[b]{2}{*}{ Median } & \multirow[b]{2}{*}{ Mean } & \multirow[b]{2}{*}{$95 \%$} & \multicolumn{3}{|c|}{ Distribution } \\
\hline & & & & & Type & $\alpha$ & $\beta$ \\
\hline FTS & $1.45 \mathrm{E}-3$ & $2.73 \mathrm{E}-3$ & $2.83 \mathrm{E}-3$ & $4.59 \mathrm{E}-3$ & Beta & 8.59 & $3.02 \mathrm{E}+03$ \\
\hline FTLR & 1.18E-3 & $3.38 \mathrm{E}-3$ & $3.73 \mathrm{E}-3$ & $7.42 \mathrm{E}-3$ & Gamma & 3.61 & $9.70 \mathrm{E}+02$ \\
\hline FTR $>1 \mathrm{H}$ & 3.78E-4 & $1.35 \mathrm{E}-3$ & $1.54 \mathrm{E}-3$ & 3.34E-3 & Gamma & 2.68 & $1.74 \mathrm{E}+03$ \\
\hline
\end{tabular}

Table 3. Industry-wide distributions of $p$ (failure probability) and $\lambda$ (hourly rate) for HPCS EDGs.

\begin{tabular}{|c|c|c|c|c|c|c|c|}
\hline \multirow{2}{*}{$\begin{array}{l}\text { Failure } \\
\text { Mode }\end{array}$} & \multirow[b]{2}{*}{$5 \%$} & \multirow[b]{2}{*}{ Median } & \multirow[b]{2}{*}{ Mean } & \multirow[b]{2}{*}{$95 \%$} & \multicolumn{3}{|c|}{ Distribution } \\
\hline & & & & & Type & $\alpha$ & $\beta$ \\
\hline FTS & $2.19 \mathrm{E}-4$ & 8.33E-4 & $9.56 \mathrm{E}-4$ & $2.12 \mathrm{E}-3$ & Beta & 2.50 & $2.61 \mathrm{E}+03$ \\
\hline FTR & $4.25 E-4$ & $1.07 \mathrm{E}-3$ & $1.15 \mathrm{E}-3$ & 2.16E-3 & Gamma & 4.50 & $3.91 \mathrm{E}+03$ \\
\hline
\end{tabular}

\subsection{EDG Failure Probability and Failure Rate Trends}

This section estimates industry-wide annual failure probabilities and failure rates for EDGs in the entire study period which covers 1998 through 2018. The estimates are trended for the most recent 10year period.

The failure probability and failure rate estimates in this section were obtained from a Bayesian update process. The means from the posterior distributions were plotted for each year. The 5th and 95th percentiles from the posterior distributions are also provided and give an indication of the relative uncertainty in the estimated parameters from year to year. When there are no failures, the interval is larger than the interval for years when there are one or more failures because of the form of the posterior variance. Each update utilizes a relatively "flat" constrained non-informative prior distribution (CNID), which has wide bounds, see [3] and NUREG/CR-6823 [8]. CNID is a compromise between an 
informative prior and the Jeffreys noninformative prior. The mean of the CNID uses prior belief and is based on a pooling of the component or event type data for the years going into the plot (i.e., the most recent 10 -year period), but the dispersion is defined to correspond to little information (i.e., relatively flat by set) so that the prior distributions did not create large changes in the data.

For failure rates or Poisson data, the CNID is a gamma distribution, with the mean $(\mu)$ given by prior belief and calculated as:

$$
\mu=\frac{\sum f_{i}+0.5}{\sum T_{i}}
$$

where $f_{i}$ and $T_{i}$ are the failures and operating/standby time for the $\mathrm{i}^{\text {th }}$ year, respectively. The CNID shape parameter $=0.5$. The posterior distribution mean for the $i^{\text {th }}$ year $\left(\mu_{i}\right)$ can be calculated as:

$$
\mu_{i}=\frac{f_{i}+0.5}{\frac{0.5}{\mu}+T_{i}}
$$

For failure probabilities or binomial data, the CNID is a beta approximation, with the mean given by prior belief and calculated as:

$$
\mu=\frac{\sum f_{i}+0.5}{\sum D_{i}+1}
$$

where $f_{i}$ and $D_{i}$ are the failures and demands for the $\mathrm{i}^{\text {th }}$ year, respectively. The CNID shape parameter $(\alpha)$ is a number between 0.3 and 0.5 based on the mean $\mu$ (see Table C.8 of [8]). The posterior distribution mean for the $\mathrm{i}^{\text {th }}$ year $\left(\mu_{i}\right)$ can be calculated as:

$$
\mu_{i}=\frac{f_{i}+\alpha}{\frac{\alpha}{\mu}+D_{i}}
$$

The horizontal curves plotted around the regression lines in the graphs form $90 \%$ simultaneous confidence bands for the fitted lines. The bounds are larger than ordinary confidence bands for the individual coefficients because they form a confidence band for the entire line. In the lower left hand corner of the trend figures, the regression p-values are reported. They come from a statistical test to assess evidence against the slope of the regression line being zero. Low p-values indicate strong evidence that the slopes are not zero, and suggest a trend does exist. P-values of less than or equal to 0.05 indicate that we are $95 \%$ confident that there is a trend in the data (reject the null hypothesis of no trend.) By convention, this study uses the "Michelin Guide" scale: p-value $<0.05$ (statistically significant), p-value $<$ 0.01 (highly statistically significant); $p$-value $<0.001$ (extremely statistically significant).

The regression methods are all based on "ordinary least squares" (OLS), which minimizes the residuals, or the square of the vertical distance between the annual data points and the fitted regression line. The p-values assume normal distributions for the residuals, with the same variability in the residuals across the years. In the case where the data involve failure counts, the iterative reweighted least squares is used to account for the fact that count data are not expected to have a constant variance (for example, the variance for Poisson-distributed counts is equal to the expected number of counts, which is expected to vary proportionally to the expected number of counts). Further information on the trending methods is provided in Section 2 of the Overview and Reference document [3].

A final feature of the trend graphs is the 2015 Update baseline industry values from Table 2 which are shown for comparison.

Figure 1 to Figure 6 provide the plots for industry-wide failure probabilities/rates of EPS and HPCS EDGs. The data for these plots are provided in Section 8. 
- Figure 1 shows the failure probability estimate trends for EPS EDG FTS.

- Figure 2 shows the failure probability estimate trends for EPS EDG FTLR.

- Figure 3 shows the failure rate estimate trends for EPS EDG FTR $>1 \mathrm{H}$.

- Figure 4 shows the failure probability estimate trends for HPCS EDG FTS.

- Figure 5 shows the failure probability estimate trends for HPCS EDG FTLR.

- Figure 6 shows the failure rate estimate trends for HPCS EDG FTR $>1 \mathrm{H}$.

No trends were identified for EPS or HPCS EDG failure probabilities/rates for FTS, FTLR, and FTR $>1 \mathrm{H}$ events in the most recent 10 -year period. 


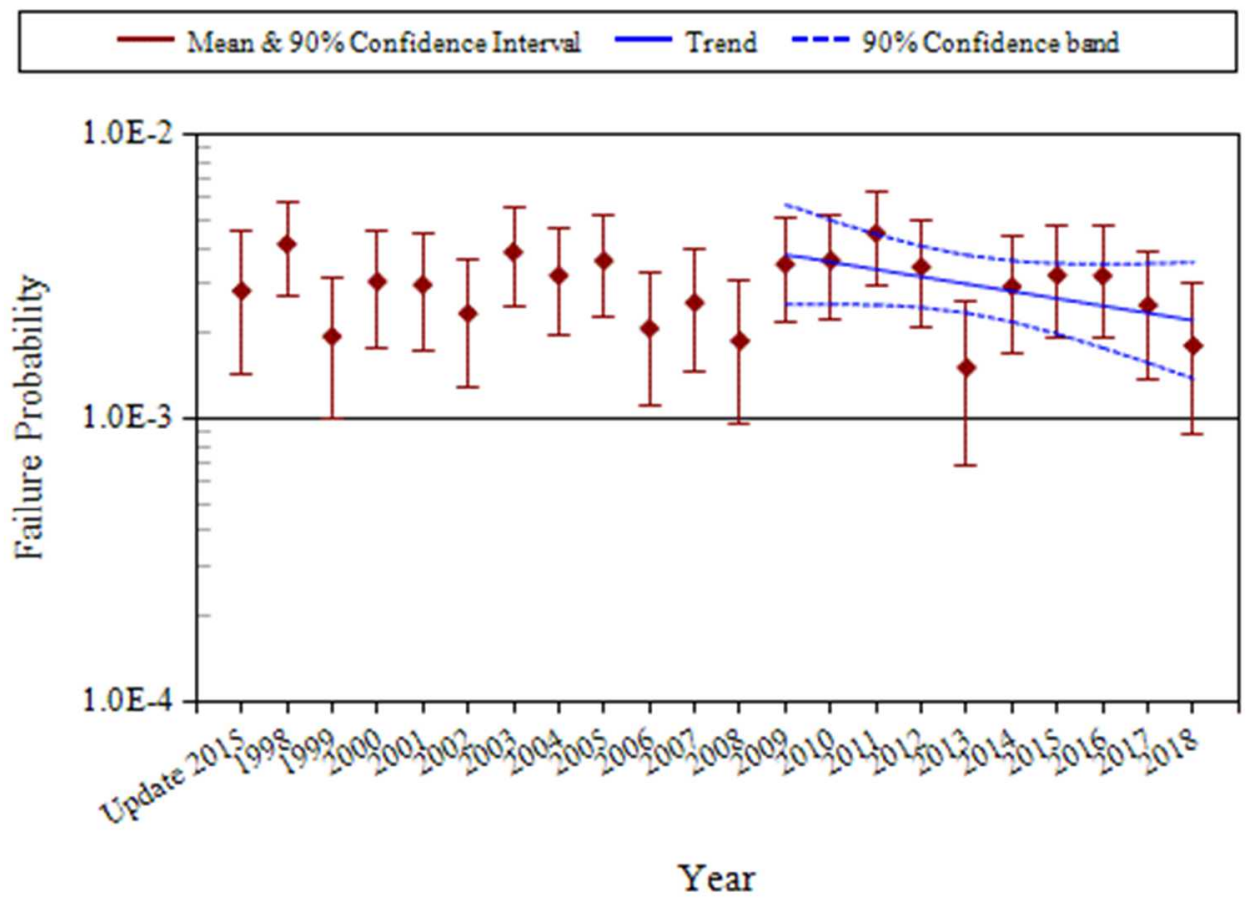

CNID, $p$-value $=0.1106$

EPS Standby GEN FTS 9/16/2019

Figure 1. Failure probability estimate trend for EPS EDG FTS.

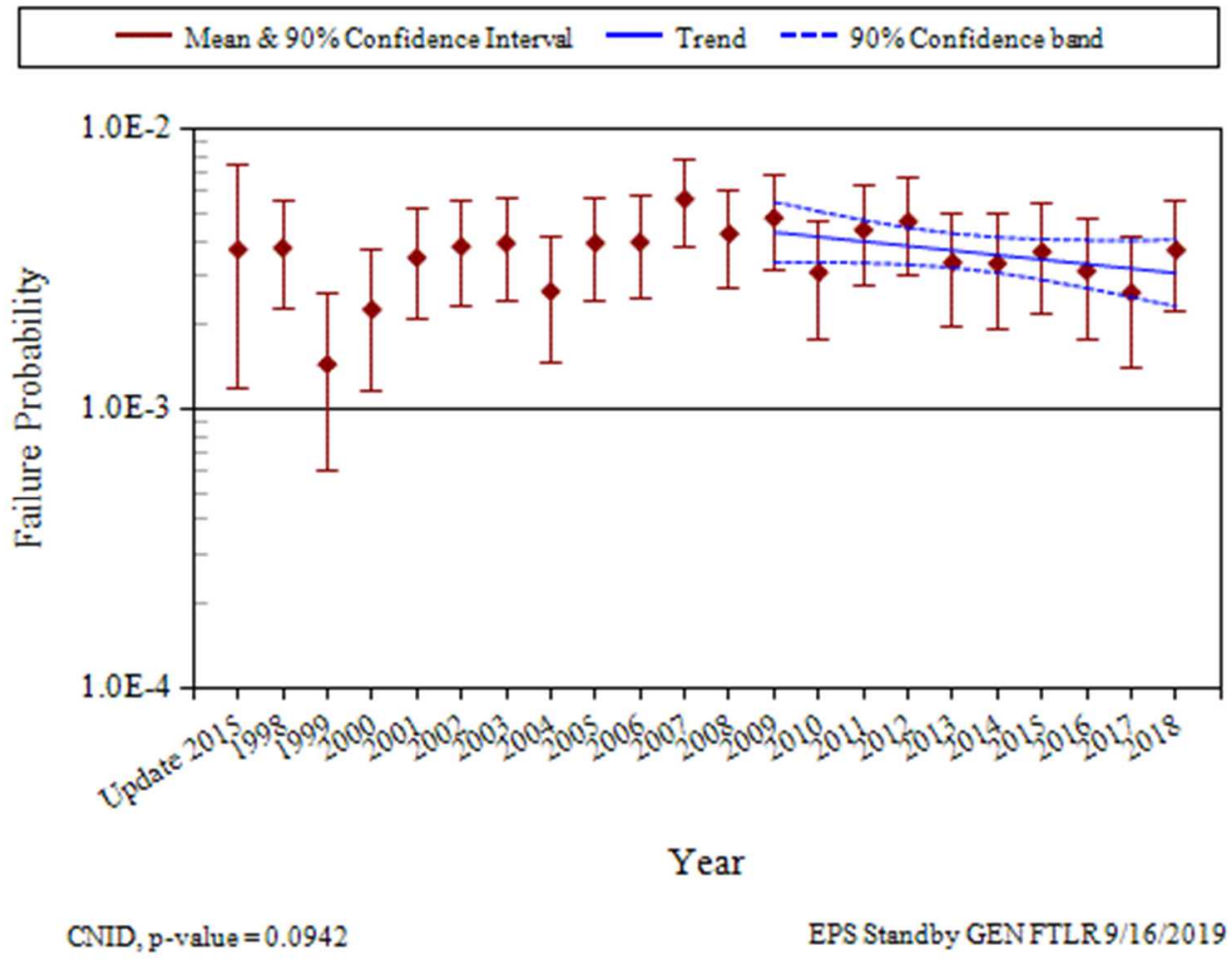

Figure 2. Failure probability estimate trend for EPS EDG FTLR. 


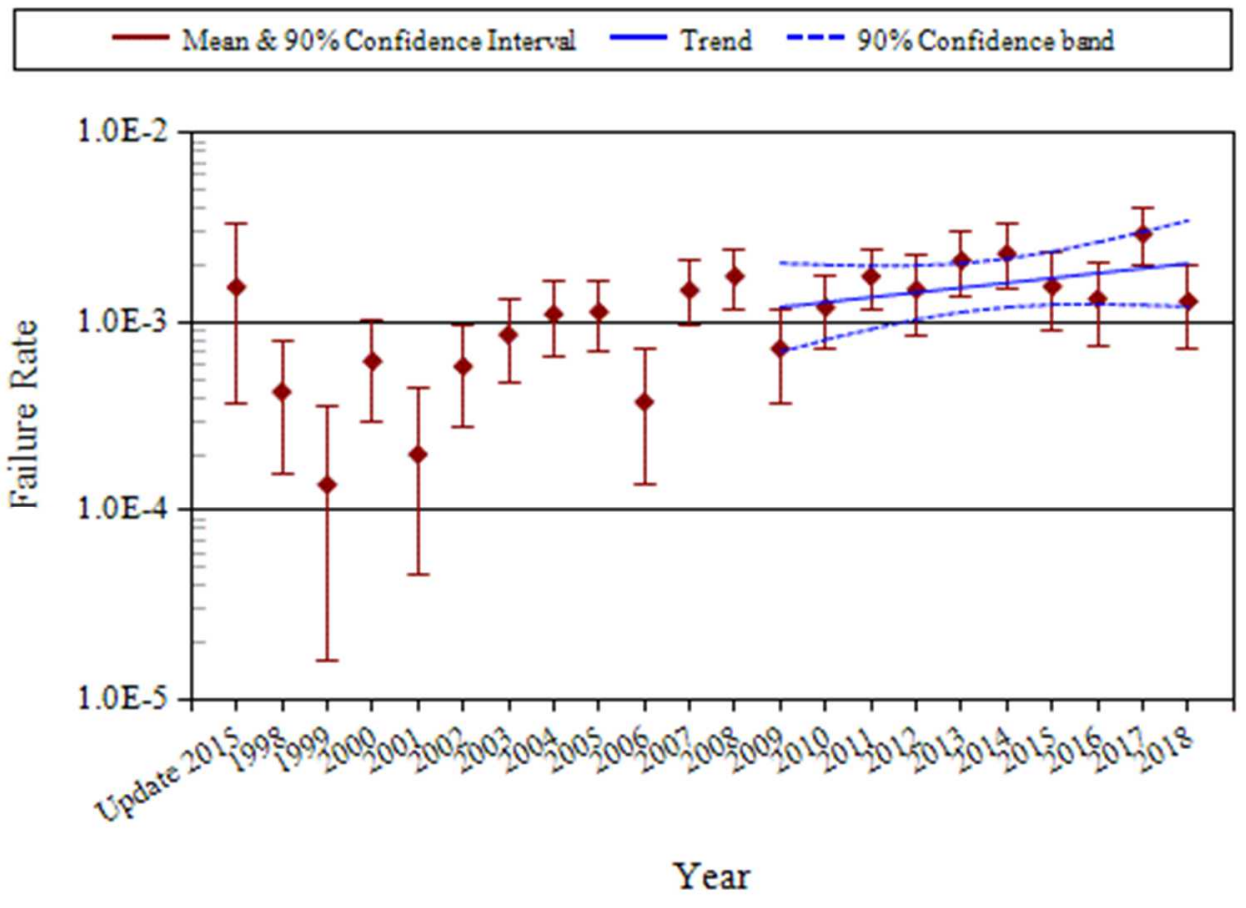

CNID, $p$-value $=0.1749$

EPS Standby GEN FTR 9/16/2019

Figure 3. Failure rate estimate trend for EPS EDG FTR $>1 H$.

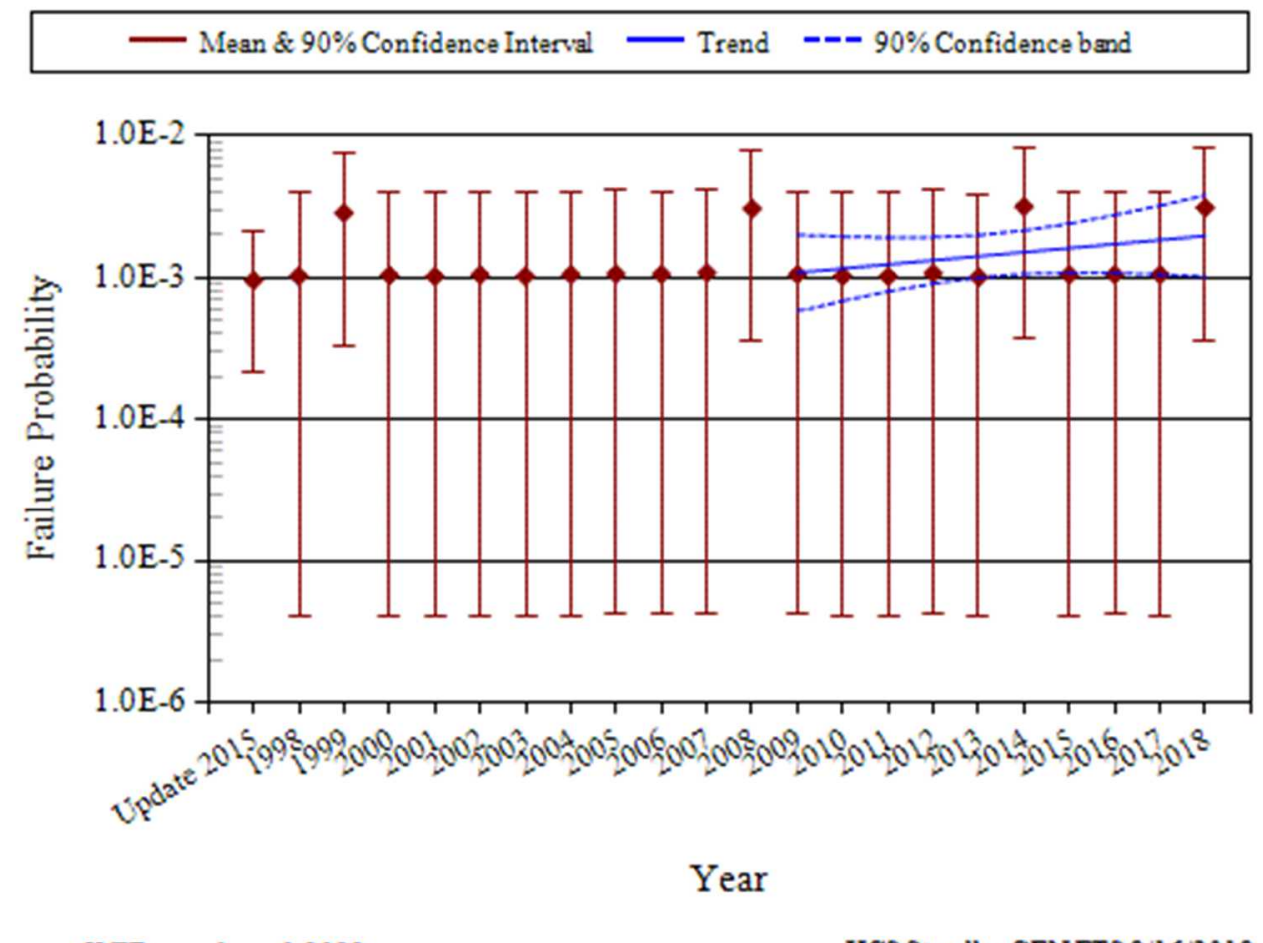

CNID, p-value $=0.2022$

HCS Standby GEN FTS 9/16/2019

Figure 4. Failure probability estimate trend for HPCS EDG FTS. 


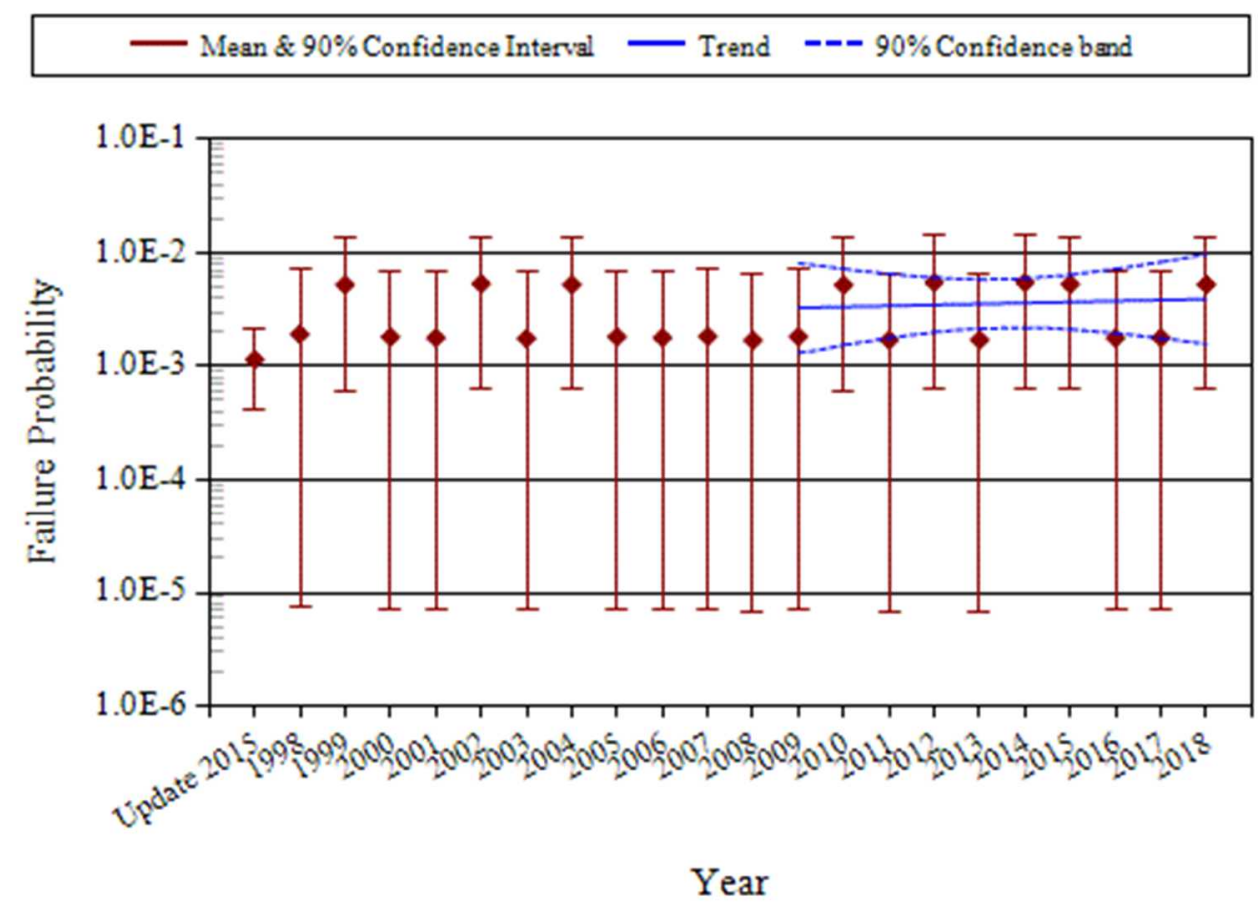

CNID, p-value $=0.7771$

HCS Standby GEN FTLR 9/16/2019

Figure 5. Failure probability estimate trend for HPCS EDG FTLR.

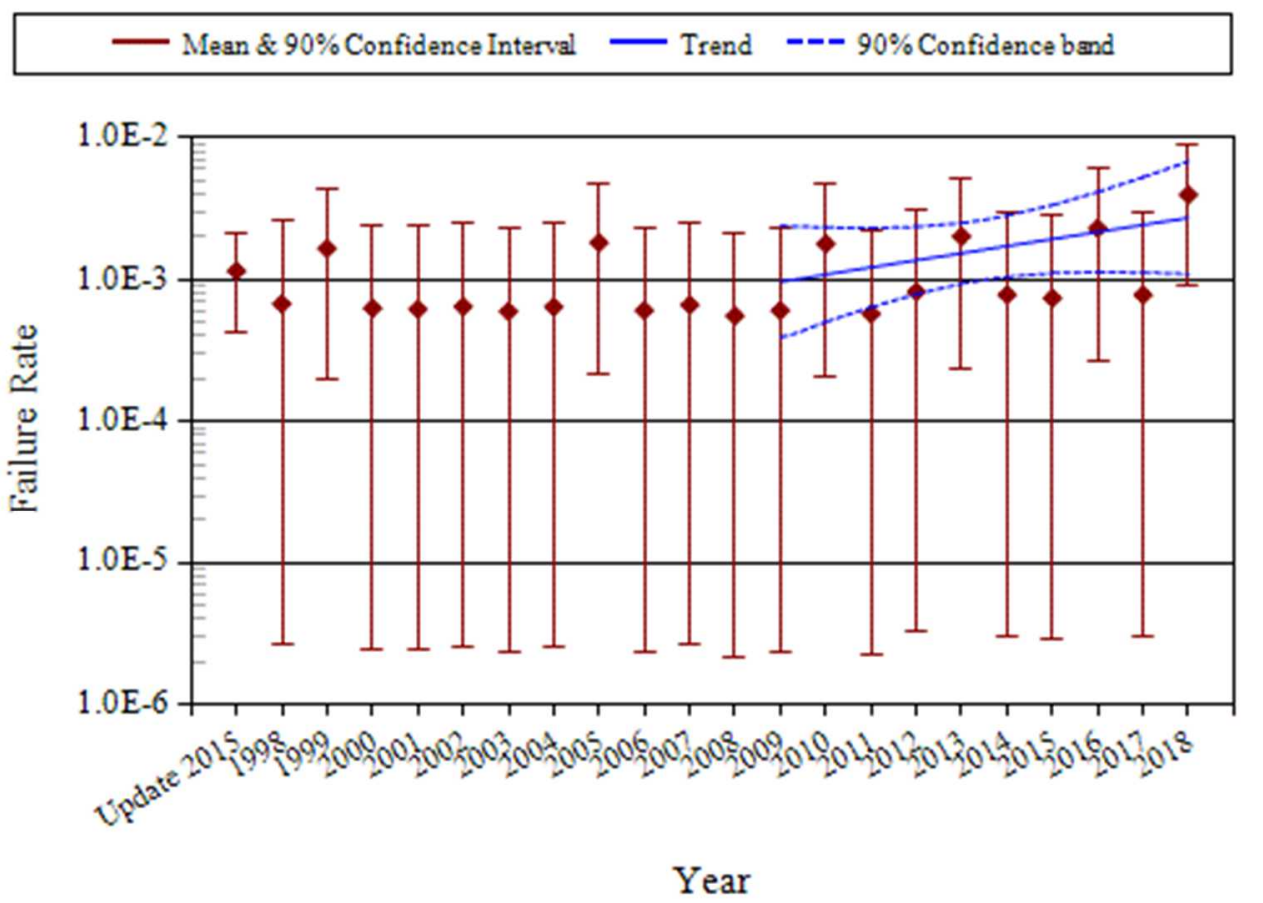

CNID, $p$-value $=0.1309$

HCS Standby GEN FTR 9/16/2019

Figure 6. Failure rate estimate trend for HPCS EDG FTR $>1 \mathrm{H}$. 


\section{EDG UNAVAILABILITY AND REPAIR TIMES}

\subsection{EDG Unavailability Overview}

The industry-wide test or maintenance UA of EDG trains has been calculated from operating experience. UA data are for EDG trains, which can include more than just the EDG. However, in most cases the EDG contributes the majority of the UA reported. Table 4 shows overall results for the EDG from the 2015 Update [6] which based on UA data from the MSPI program and ICES. In the calculations, planned and unplanned unavailable hours for a train are combined.

Table 4. 2015 Update industry-average unavailability estimates for EPS EDGs.

\begin{tabular}{lllcc}
\hline \multicolumn{1}{c}{ Description } & Distribution & Mean & $\boldsymbol{\alpha}$ & $\boldsymbol{\beta}$ \\
\hline EDG Test or Maintenance (EPS) & Normal & $1.48 \mathrm{E}-2$ & 0.0148 & 0.0063 \\
EDG Test or Maintenance (HPCS) & Normal & $1.17 \mathrm{E}-2$ & 0.0117 & 0.0025 \\
\hline
\end{tabular}

\subsection{EDG Unavailability Trends}

The graphs that follow provide overall maintenance unavailability, planned (such as test) and unplanned, data for the 1998-2018 period. Note that these data do not supersede the data in Table 4 for use in risk assessments.

Trends in EDG train unavailability are shown in Figure 7 and Figure 8. Data tables for these figures are presented in Section 8. The EDGs in systems EPS and HPCS are trended. The yearly unavailability and reactor critical hour data were obtained from the Reactor Oversight Process program (1998 to 2001) and MSPI EPS indicator (2002 to 2018). The total EDG downtimes during operation for each plant and year were summed and divided by the corresponding number of EDG-reactor critical hours. Unavailability data for plant shutdown periods are not reported.

A change in reporting requirements for UA occurred in 2002. The Reactor Oversight Process program data (1998-2001) did not include EDG overhaul outages while plants were in critical operation, while the MSPI (2002-2018) requires plants to report such outages. The difference in the annual means of these two groups is not statistically significant.

The mean and variance for each year is the sample mean and variance calculated from the plant-level unavailability's for that year. The vertical bar spans the calculated 5th to 95th percentiles of the beta distribution with matching means.

For the trend graphs, a least squares fit is sought for the linear or logit model. Section 3 in the Overview and Reference document provides further information [3]. In the lower left hand corner of the trend figures, the p-value is reported. A review of the p-values identified no statistically significant trends in EDG unavailability for the most recent 10 -year period. 


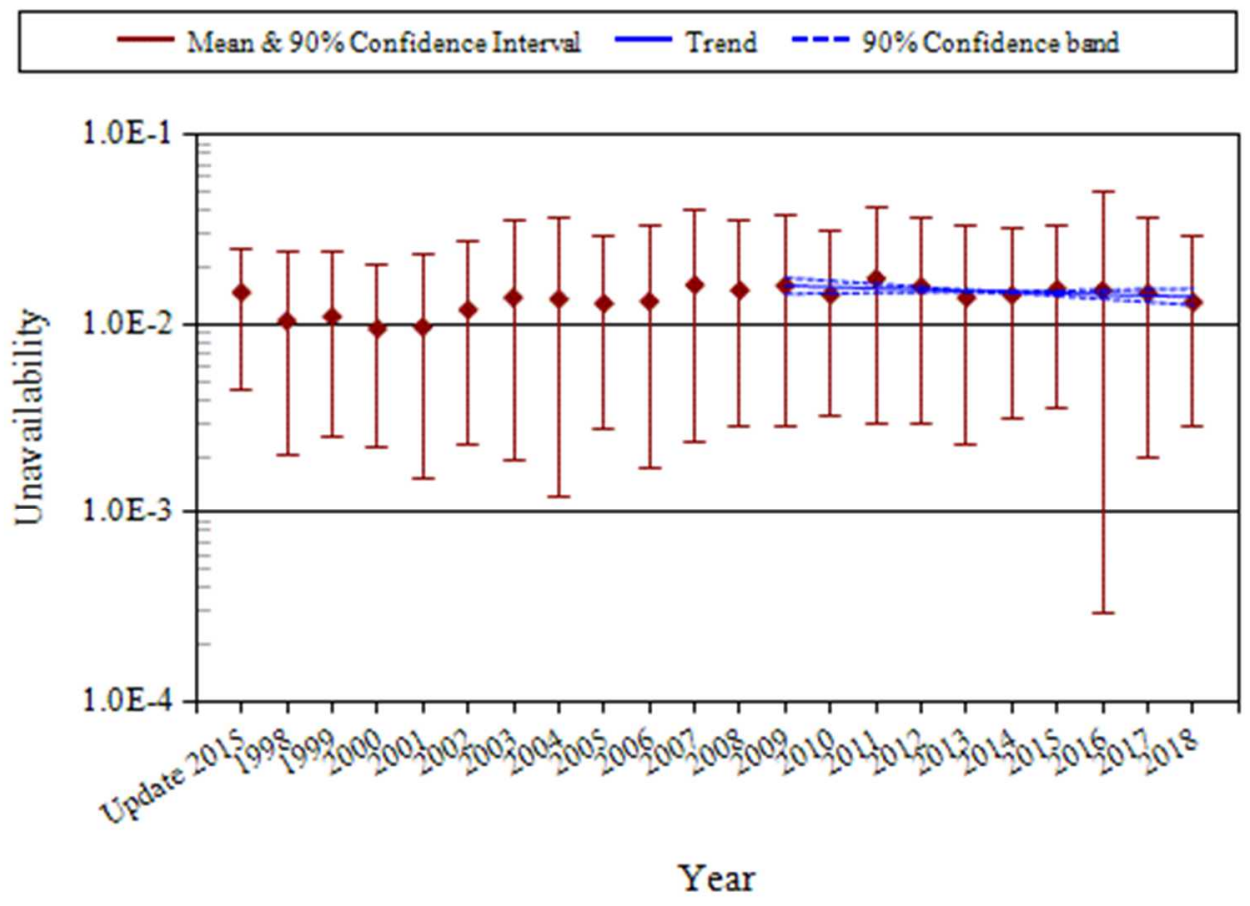

Logit, $p$-value $=0.1532$

EPS Standby GENUA 9/16/2019

Figure 7. EPS EDG UA trend.
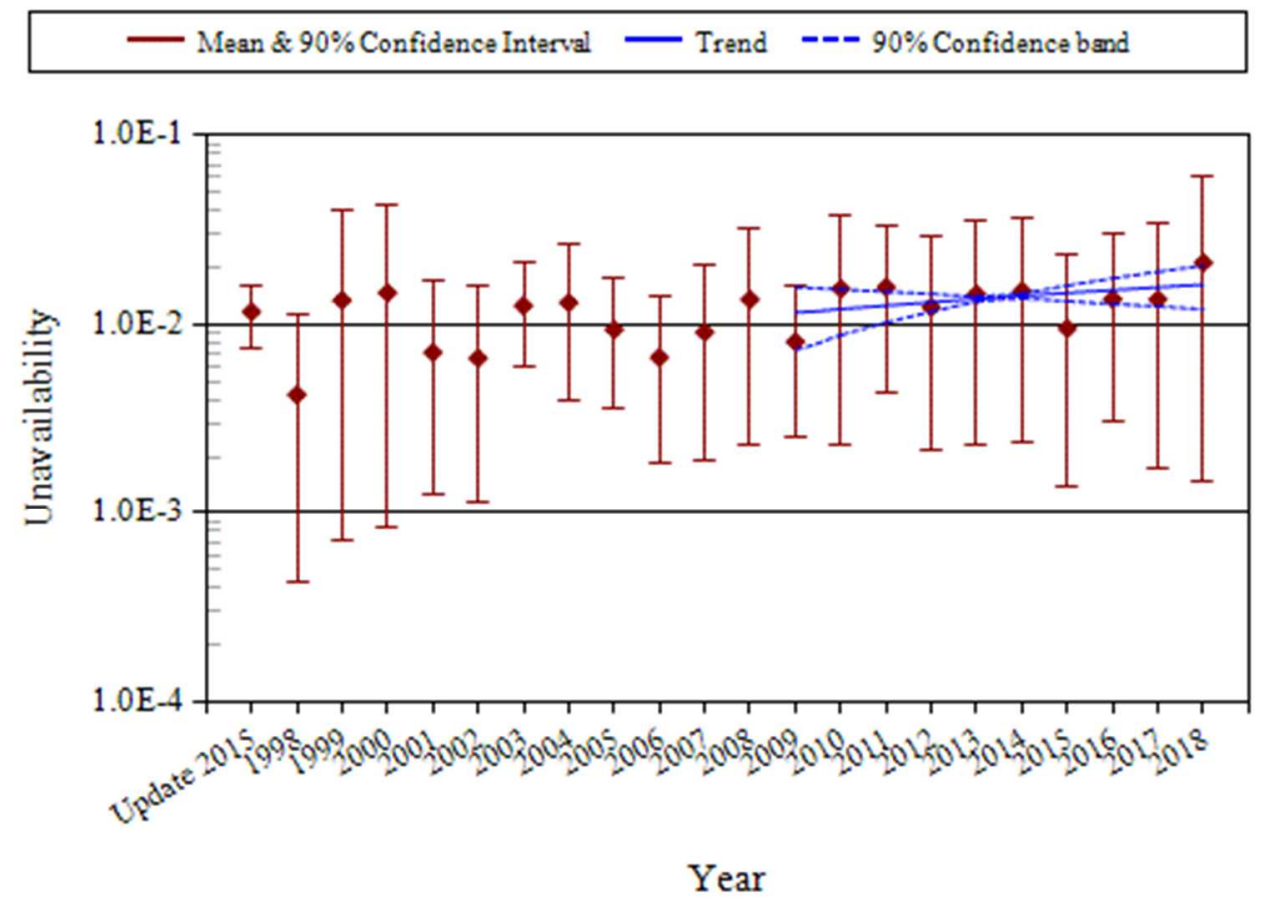

Linear, $p$-value $=0.2925$

HCS Standby GENUA 9/16/2019

Figure 8. HPCS EDG UA trend. 


\subsection{Emergency Diesel Generator Repair Times}

The data for repair times performed under actual emergency conditions are not available so repair durations were based on the number of hours of unplanned unavailability that have been reported for each EDG from 2009 to 2018 . The hourly unplanned unavailability is reported to the NRC in the MSPI data. This MSPI data were not reported prior to 2006.

A Weibull distribution was fitted to the unplanned unavailability durations. The Weibull fit parameters are provided in Table 5. The probability an EDG unplanned outage duration exceeds a given time $(t)$ is listed in Table 6 . The correspondence between fitted and observed distributions is very good at short to moderate times but not as good at very long repair times (well beyond typical PRA missions), such as when the outage spans hundreds of hours. In that situation, the long right tail of the repair time distribution is fit better by a lognormal distribution than a Weibull.

Table 5. Weibull curve fit parameters.

\begin{tabular}{lc}
\hline Parameter & Value \\
\hline Mean & 34.2 \\
Median & 15.4 \\
Weibull( $\alpha$ ) & 0.681 \\
Weibull $(\beta)$ & 26.3 \\
\hline
\end{tabular}


Table 6. Probability of exceeding selected EDG repair times (2009-2018).

\begin{tabular}{cc}
\hline $\begin{array}{c}\text { Recovery } \\
\text { Time (hr) }\end{array}$ & $\begin{array}{c}\text { Weibull Model } \\
\text { Probability }\end{array}$ \\
\hline 0.5 & 0.935 \\
\hline 1 & 0.898 \\
1.5 & 0.868 \\
\hline 2 & 0.841 \\
\hline 3 & 0.796 \\
\hline 4 & 0.758 \\
\hline 5 & 0.724 \\
\hline 6 & 0.694 \\
\hline 7 & 0.667 \\
\hline 8 & 0.641 \\
\hline 9 & 0.618 \\
\hline 10 & 0.596 \\
\hline 11 & 0.576 \\
\hline 12 & 0.557 \\
13 & 0.539 \\
\hline 14 & 0.522 \\
\hline 15 & 0.506 \\
\hline 16 & 0.491 \\
17 & 0.476 \\
\hline 18 & 0.462 \\
\hline 19 & 0.449 \\
\hline 20 & 0.436 \\
\hline 22 & 0.424 \\
\hline 24 & 0.413 \\
\hline & 0.402 \\
\hline 1 & 0.391 \\
\hline 123 & \\
\hline
\end{tabular}




\section{EDG UNRELIABILITY TRENDS}

Trends in total component unreliability are shown in Figure 9 and Figure 10. Plot data for these figures are provided in Section 8. Total unreliability is defined as the union of UA, FTS, FTLR, FTR $>1 \mathrm{H}$. The probability of FTR $>1 \mathrm{H}$ is calculated for 7 hours to provide the results for an 8-hour mission. The trends are shown at the system-specific level across the industry. The trending method is described in more detail in Section 4 of the Overview and Reference document [3]. In the lower left hand corner of the trend figures, the regression method and the $p$-value are reported. A review of the $p$-values identifies no statistically significant trends in the EDG total unreliability estimates for the most recent 10year period.

No "2015 Update" data for use in risk assessments are cited for EDG unreliability because these data are generated a-priori. The risk assessment models compute unreliability as an output rather than an input.

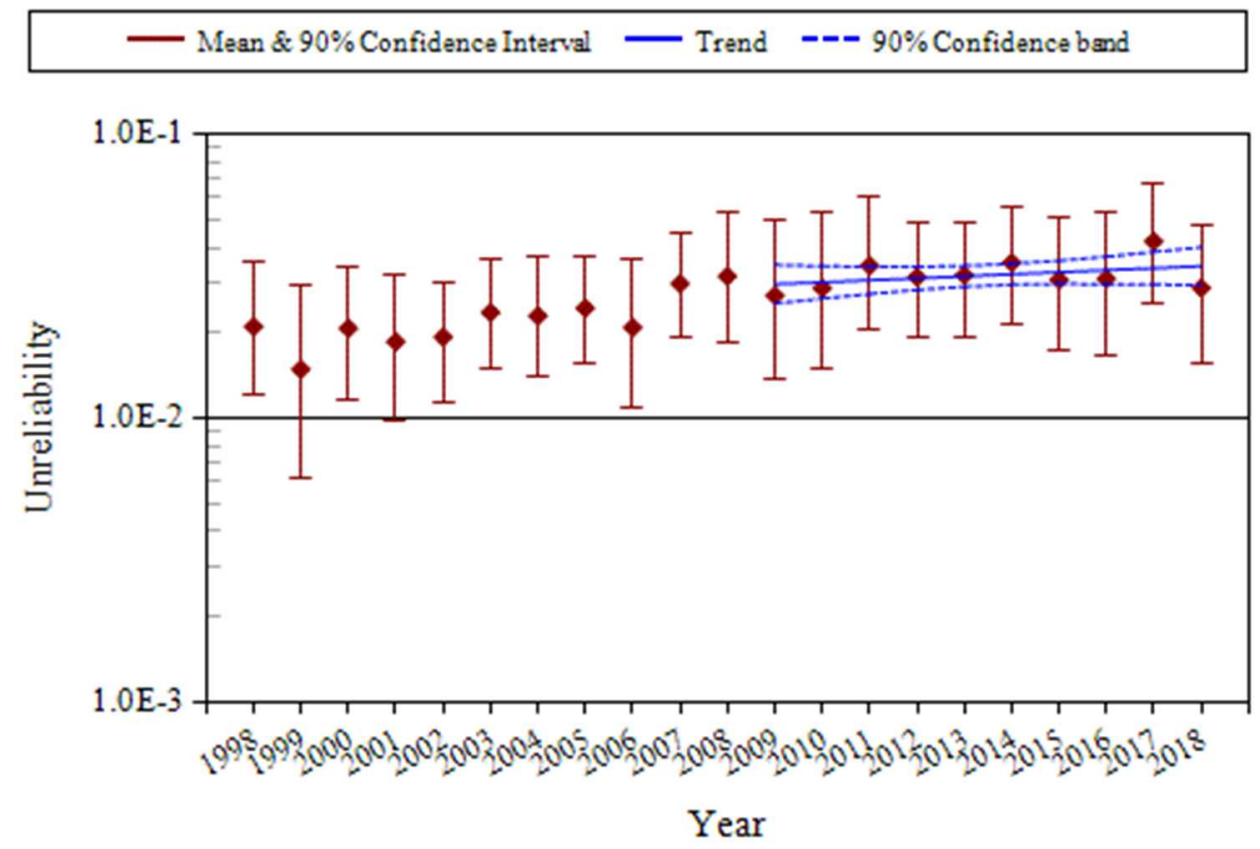

LogLinear, $p$-value $=0.2599$

EPS Standby GEN Total 9/16/2019

Figure 9. EPS EDG unreliability trend (8-hour mission). 


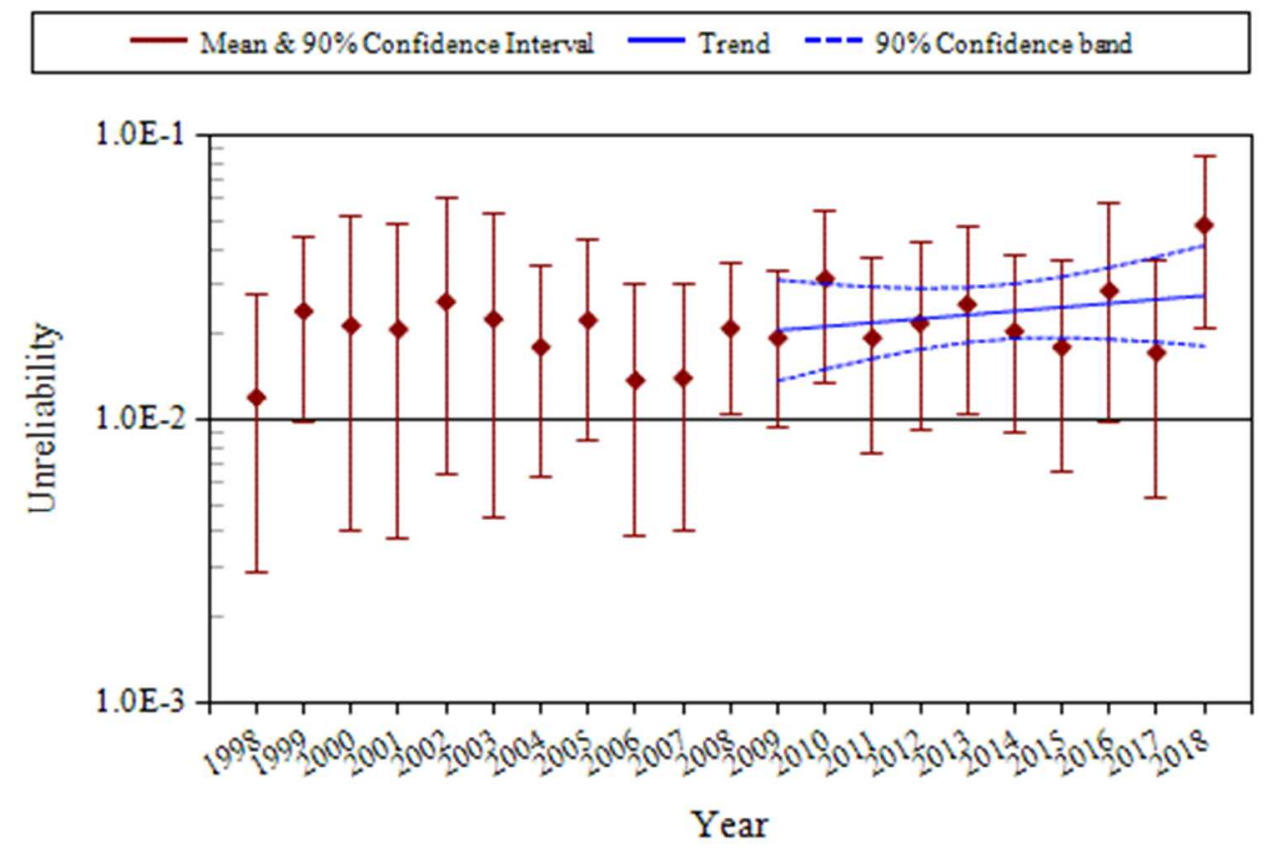

LogLinear, $p$-value $=0.4044$

HCS Standby GEN Total 9/16/2019

Figure 10. HPCS EDG unreliability trend (8-hour mission). 


\section{ENGINEERING ANALYSIS}

This section present the engineering analysis for factors that could influence the system and component trends. Engineering trends of component failures and demands are presented in Section 6.1. Differences between testing and actual unplanned demands are considered in Section 6.2. Differences among manufacturers are presented in Section 6.3, and differences among EDG ratings are presented in Section 6.4. Finally, engineering analyses performed with respect to failure mode are presented in Section 6.5. The failure mode factors analyzed were: sub-component, failure cause, detection method, manufacturer, and EDG rating.

\subsection{Engineering Trends}

This section presents frequency trends for EPS and HPCS EDG failures and demands. The data are normalized by reactor year for plants that report data for these EDGs, with no consideration for plant system (EPS versus HPCS) or for the number of EDGs at a plant. The trends provide an overview of the demand counts and failure counts associated with each failure mode across the years.

- Figure 11 shows the trend for EPS and HPCS EDG frequency of start demands.

- Figure 12 shows the trend for EPS and HPCS EDG frequency of load and run demands.

$\circ$ Figure 13 shows the trend for the EPS and HPCS EDG frequency of run hours.

- Figure 14 shows the trend for EPS and HPCS EDG frequency of FTS events.

$\circ$ Figure 15 shows the trend EPS and HPCS EDG frequency of FTLR events.

- Figure 16 shows the trend for the EPS and HPCS EDG frequency of FTR $>1 \mathrm{H}$ events.

The data for the above figures are provided in Section 8 . The standby systems from Table 1 are trended together for each figure. The rate methods described in Section 2 of the Overview and Reference document are used [6].

In the lower left hand corner of the above trend figure, the regression p-values are reported. A review of these $\mathrm{p}$-values identified the following trend for the most recent 10 -year period:

- Statistically significant increasing trend in the frequency of FTLR demands for EPS and HPCS EDGs, with a p-value of 0.0165 (see Figure 12). This is a new trend that was not observed in the 2016 EDG update study [2].

- Statistically significant decreasing trend in the frequency of run $>1 \mathrm{H}$ hours for EPS and HPCS EDGs, with a p-value of 0.0198 (see Figure 13). This trend has been observed in the 2016 EDG update study as highly statistically significant.

Table 7-Table 9 provide a summary of the total failure event count for each of the years for which a trend line is plotted. Table 7 summarizes the failures by system and year for the FTS failure mode. Table 8 summarizes the failures by system and year for the FTLR failure mode. Table 9 summarizes the failures by system and year for the FTR $>1 \mathrm{H}$ failure mode. The data in Table 7 -Table 9 show failure events resulting from FTLR and FTR $>1 \mathrm{H}$ occur in roughly equal numbers, while FTS failures occur somewhat less frequently than FTLR and FTR $>1 \mathrm{H}$ failures. Furthermore, HPCS EDGs are about 3 percent of the EDG population, but account for only 1 to 2 percent of the failure counts throughout the period being trended. 


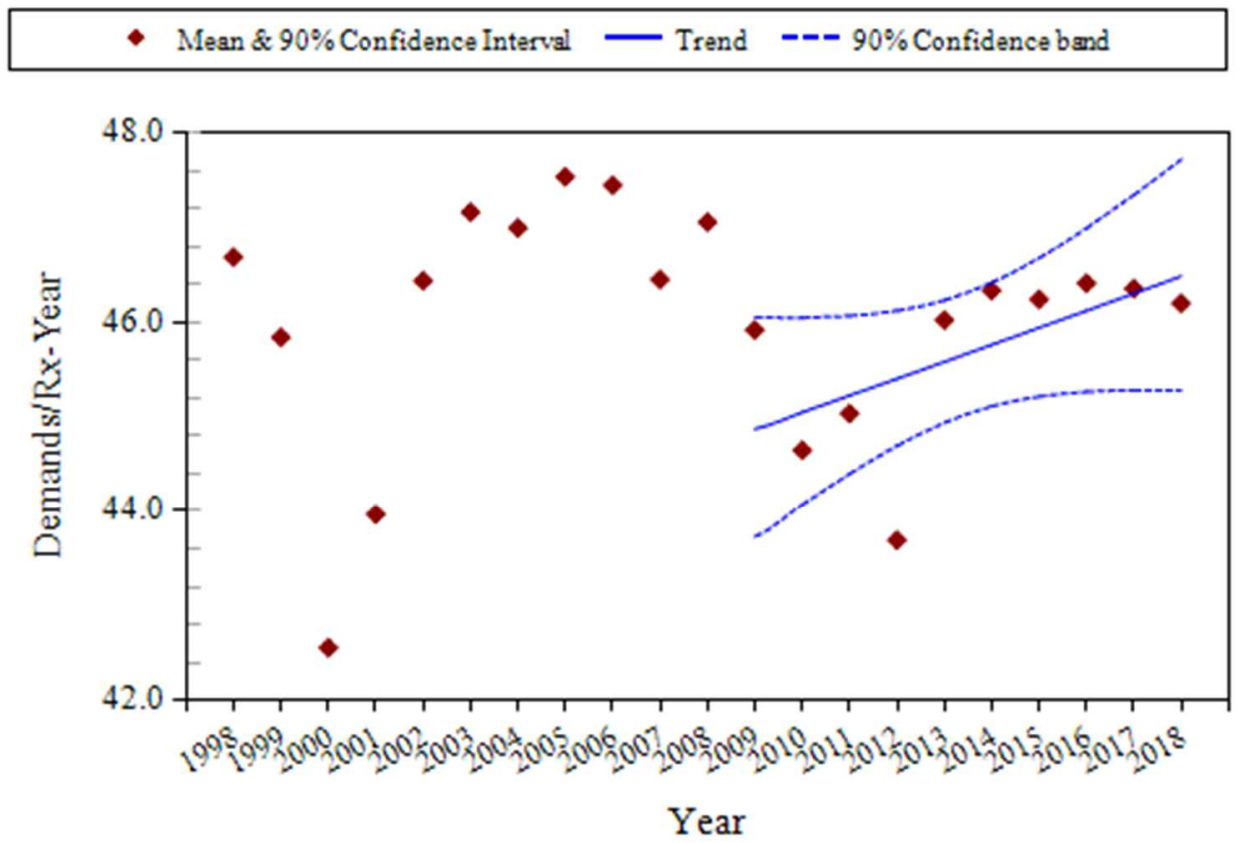

CNID, $p$-value $=0.0799$

All Standby GEN FTS 9/16/2019

Figure 11. Frequency of start demands (demands per reactor year) for EPS and HPCS EDGS.

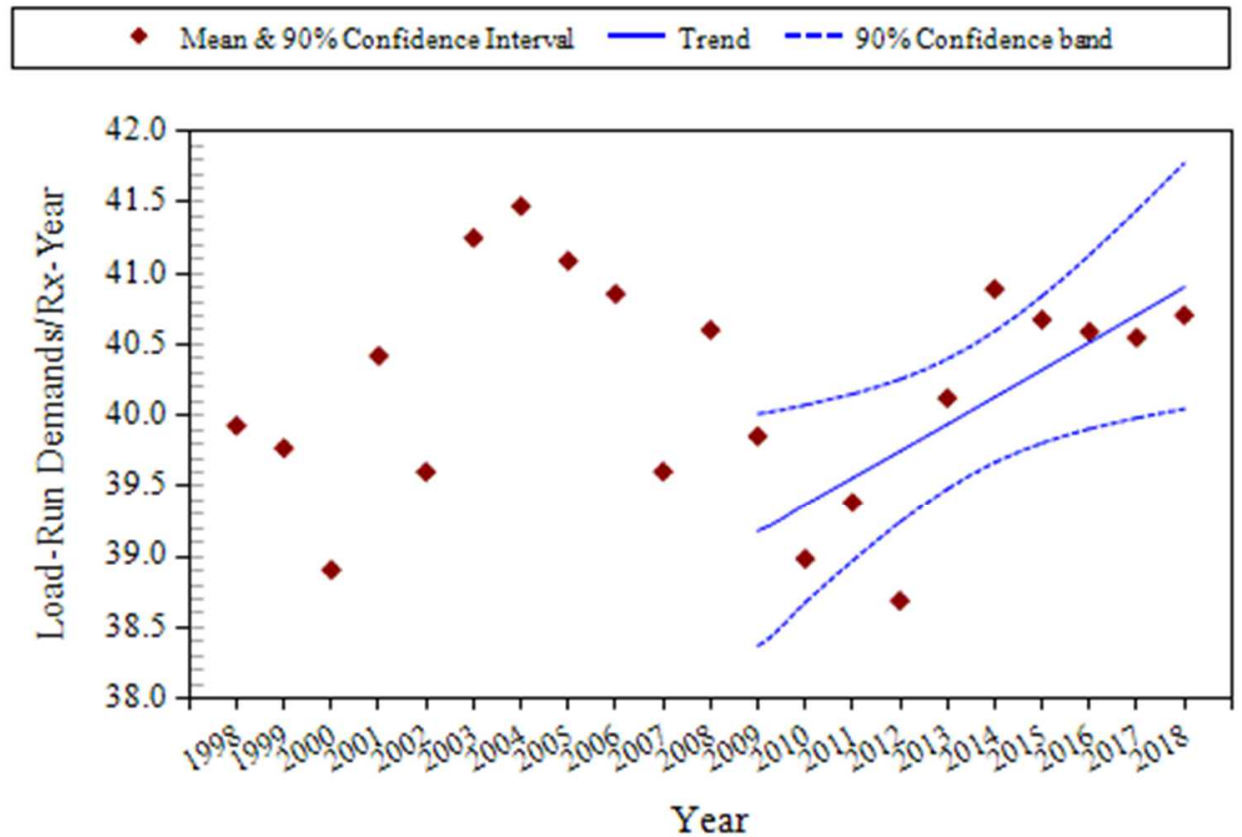

CNID, $p$-value $=0.0165$

All Standby GEN FTLR 9/16/2019

Figure 12. Frequency of FTLR demands (demands per reactor year) trend for EPS and HPCS EDGs. 


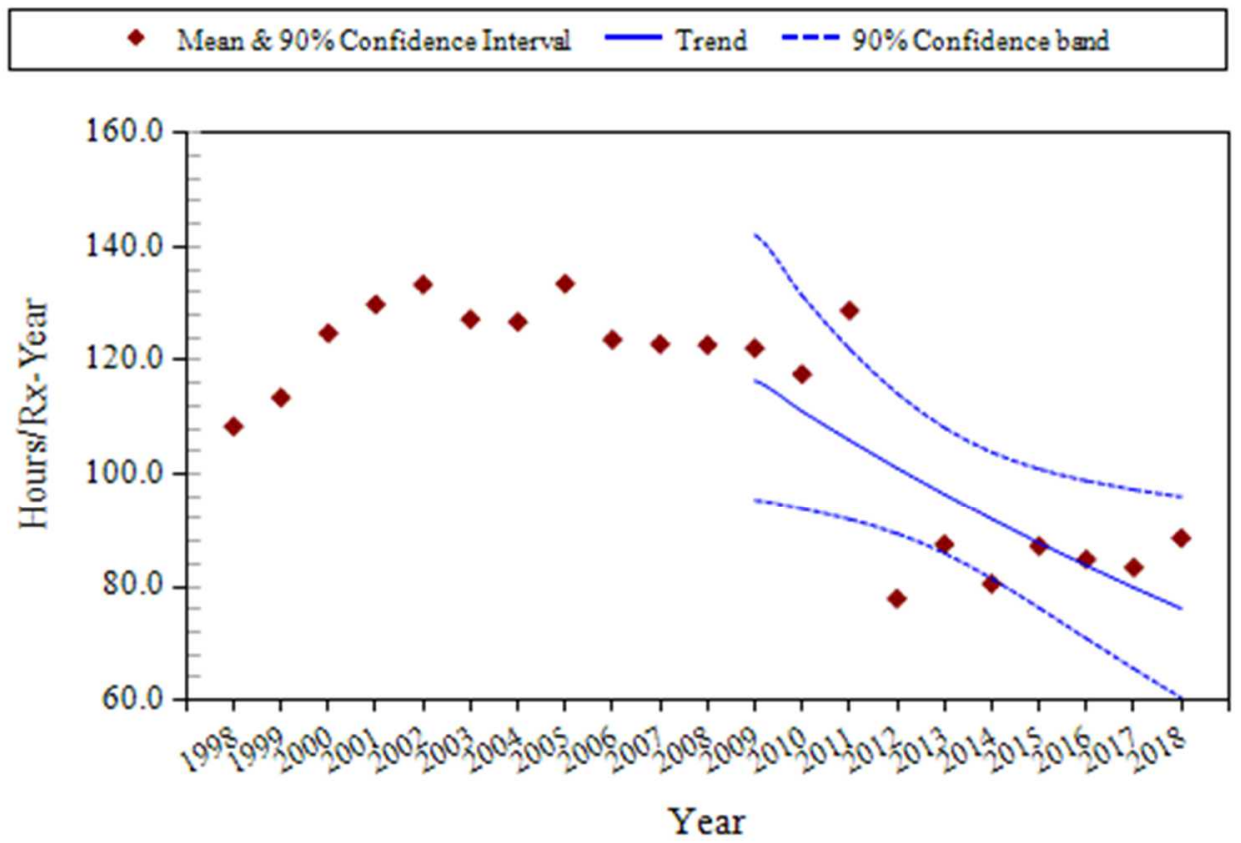

CNID, $p$-value $=0.0198$

All Standby GEN FTR 9/16/2019

Figure 13. Frequency of run $>1$ H hours (hours per reactor year) trend for EPS and HPCS EDGs.

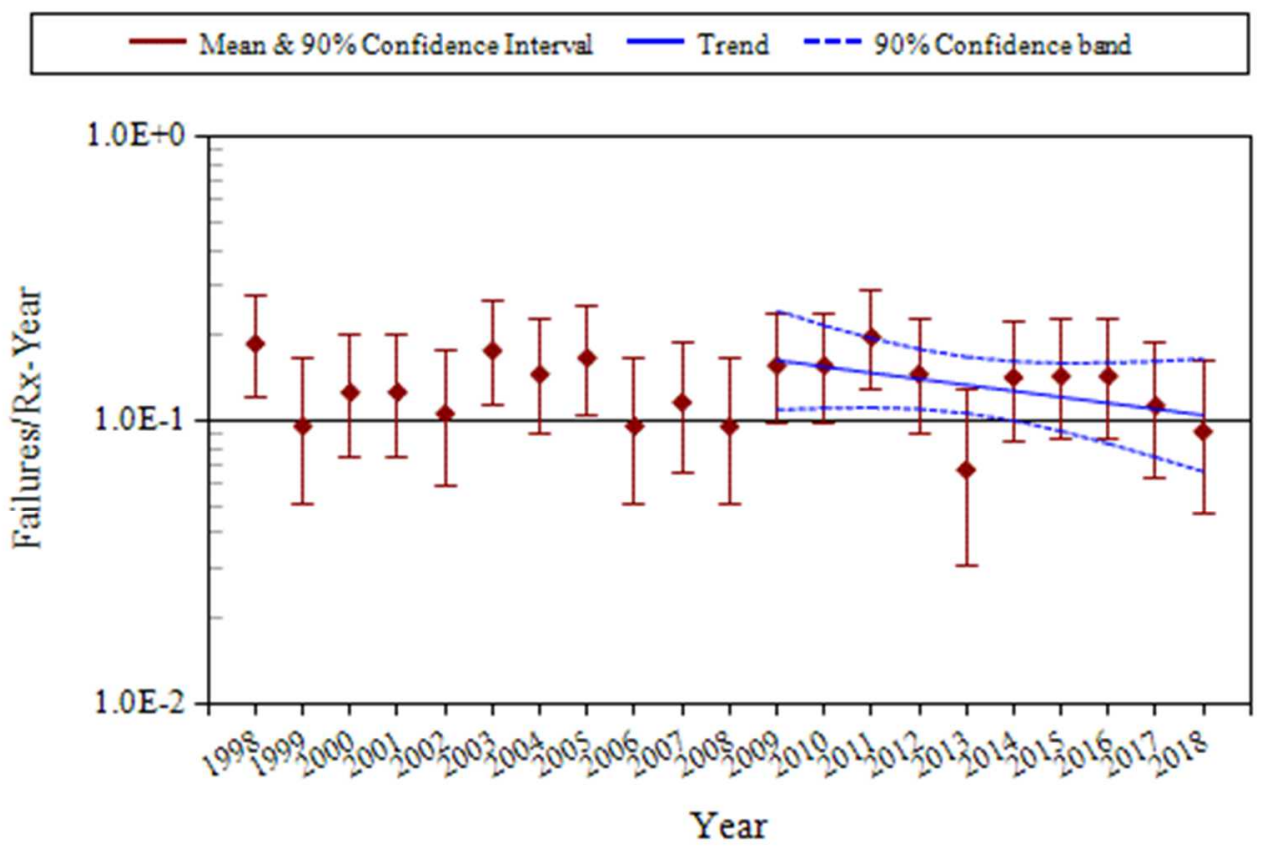

CNID, $p$-value $=0.1655$

All Standby GEN FTS 9/16/2019

Figure 14. Frequency of FTS events (events per reactor year) trend for EPS and HPCS EDGs. 


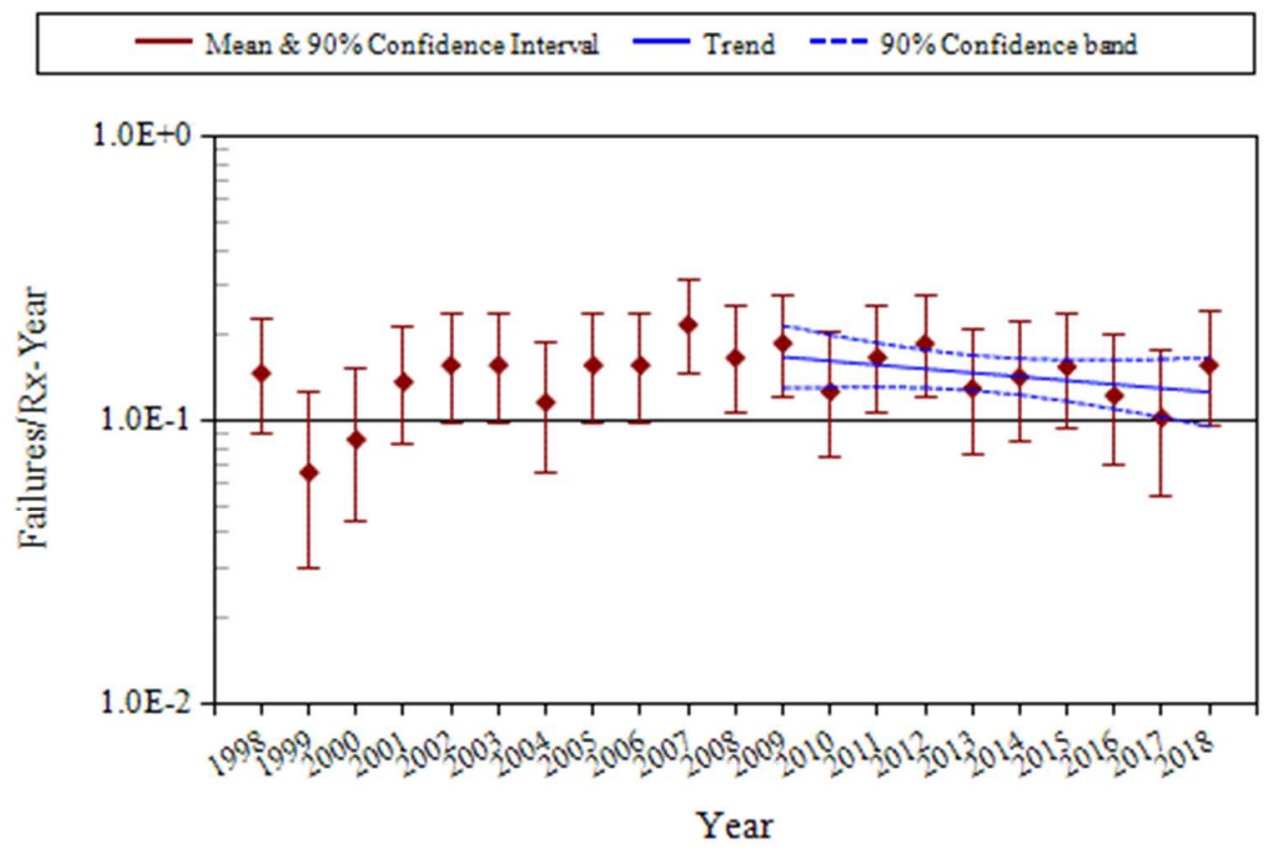

CNID, $p$-value $=0.1529$

All Standby GEN FTLR 9/16/2019

Figure 15. Frequency of FTLR events (events per reactor year) trend for EPS and HPCS EDGs.

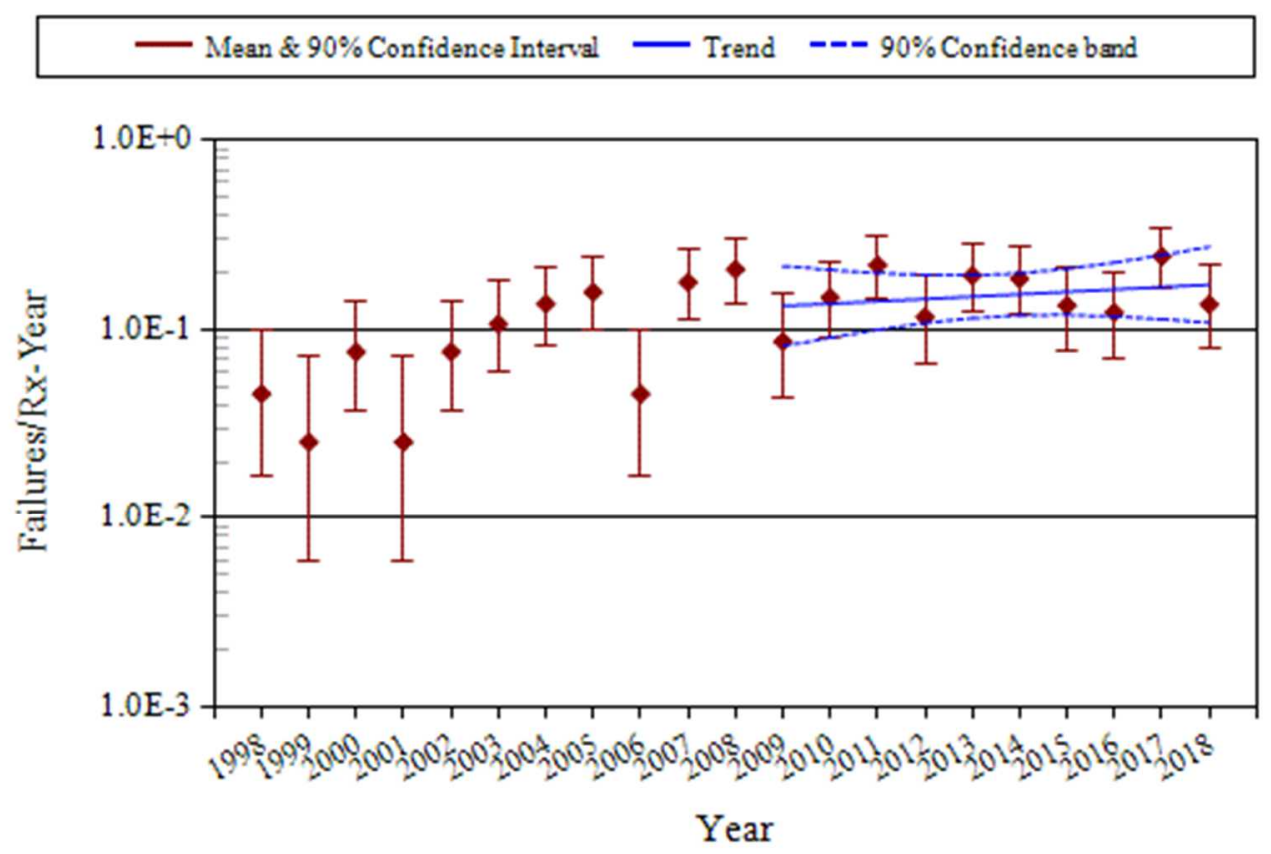

CNID, $p$-value $=0.4395$

All Standby GEN FTR 9/16/2019

Figure 16. Frequency of FTR $>1 H$ events (events per reactor year) trend for EPS and HPCS EDGs. 
Table 7. Summary of EDG failure counts for the FTS failure mode over time by system.

\begin{tabular}{|c|c|c|c|c|c|c|c|c|c|c|c|c|c|c|}
\hline \multirow[b]{2}{*}{ System } & \multirow[b]{2}{*}{$\begin{array}{l}\text { EDG } \\
\text { Count }\end{array}$} & \multirow[b]{2}{*}{$\begin{array}{c}\text { EDG } \\
\text { Percent }\end{array}$} & \multicolumn{10}{|c|}{ Year } & \multirow[b]{2}{*}{ Total } & \multirow{2}{*}{$\begin{array}{c}\text { Percent } \\
\text { of } \\
\text { Failures }\end{array}$} \\
\hline & & & 2009 & 2010 & 2011 & 2012 & 2013 & 2014 & 2015 & 2016 & 2017 & 2018 & & \\
\hline EPS & 232 & $96.7 \%$ & 15 & 15 & 19 & 14 & 6 & 12 & 13 & 13 & 10 & 7 & 124 & $98.4 \%$ \\
\hline HPCS & 8 & $3.3 \%$ & & & & & & 1 & & & & 1 & 2 & $1.6 \%$ \\
\hline Total & 240 & $100 \%$ & 15 & 15 & 19 & 14 & 6 & 13 & 13 & 13 & 10 & 8 & 126 & $100 \%$ \\
\hline
\end{tabular}

Table 8. Summary of EDG failure counts for the FTLR failure mode over time by system.

\begin{tabular}{|c|c|c|c|c|c|c|c|c|c|c|c|c|c|c|}
\hline \multirow[b]{2}{*}{ System } & \multirow[b]{2}{*}{$\begin{array}{l}\text { EDG } \\
\text { Count }\end{array}$} & \multirow[b]{2}{*}{$\begin{array}{c}\text { EDG } \\
\text { Percent }\end{array}$} & \multicolumn{10}{|c|}{ Year } & \multirow[b]{2}{*}{ Total } & \multirow{2}{*}{$\begin{array}{c}\text { Percent } \\
\text { of } \\
\text { Failures }\end{array}$} \\
\hline & & & 2009 & 2010 & 2011 & 2012 & 2013 & 2014 & 2015 & 2016 & 2017 & 2018 & & \\
\hline EPS & 232 & $96.7 \%$ & 18 & 11 & 16 & 17 & 12 & 12 & 13 & 11 & 9 & 13 & 132 & $96.4 \%$ \\
\hline HPCS & 8 & $3.3 \%$ & & 1 & & 1 & & 1 & 1 & & & 1 & 5 & $3.6 \%$ \\
\hline Total & 240 & $100 \%$ & 18 & 12 & 16 & 18 & 12 & 13 & 14 & 11 & 9 & 14 & 137 & $100 \%$ \\
\hline
\end{tabular}

Table 9. Summary of EDG failure counts for the FTR $>1$ H failure mode over time by system.

\begin{tabular}{|c|c|c|c|c|c|c|c|c|c|c|c|c|c|c|}
\hline \multirow[b]{2}{*}{ System } & \multirow[b]{2}{*}{$\begin{array}{l}\text { EDG } \\
\text { Count }\end{array}$} & \multirow[b]{2}{*}{$\begin{array}{c}\text { EDG } \\
\text { Percent }\end{array}$} & \multicolumn{10}{|c|}{ Year } & \multirow[b]{2}{*}{ Total } & \multirow{2}{*}{$\begin{array}{c}\text { Percent } \\
\text { of } \\
\text { Failures }\end{array}$} \\
\hline & & & 2009 & 2010 & 2011 & 2012 & 2013 & 2014 & 2015 & 2016 & 2017 & 2018 & & \\
\hline EPS & 232 & $96.7 \%$ & 8 & 13 & 21 & 11 & 17 & 17 & 12 & 10 & 22 & 10 & 141 & $96.6 \%$ \\
\hline HPCS & 8 & $3.3 \%$ & & 1 & & & 1 & & & 1 & & 2 & 5 & $3.4 \%$ \\
\hline Total & 240 & $100 \%$ & 8 & 14 & 21 & 11 & 18 & 17 & 12 & 11 & 22 & 12 & 146 & $100 \%$ \\
\hline
\end{tabular}

\subsection{Comparison of ICES EPS EDG Unplanned Demand Results with Industry Results}

Because the ICES EPS EDG data are dominated by test demands (over 95\% of the demands are typically from tests), an ongoing concern is whether these mostly test data adequately predict EPS EDG performance during unplanned demands. This comparison evaluates the same dataset for standby components that is used for the overall trends shown in this document, but limits the failure data to those that are discovered during an ESF demand that was reported in ICES. The data are further limited to 2003 to present since the ESF demand reporting in ICES is inconsistent prior to 2003.

To answer this question, ICES failure records were reviewed to identify actual unplanned EPS EDG demands involving bus under voltage conditions. Such events require the associated EPS EDG to start, load onto the bus and power the bus until normal power is recovered to the bus. There are additional EPS EDG unplanned demands in which a bus under voltage condition did not exist. In those cases, the EPS EDG did not have to load and power the bus. Such unplanned demands do not fully exercise the mission of the EPS EDGs and therefore were not counted.

The EPS EDG unplanned demand data covering 2003 - 2018 are summarized in Table 10. Consistency between the unplanned demand data and 2015 Update industry-average performance (from Table 2) was evaluated using the predictive distribution approach outlined in the Handbook of Parameter Estimation for Probabilistic Risk Assessment, NUREG/CR-6823, Sections 6.2.3.5 and 6.3.3.4 [8].

The unplanned demand data were aggregated at the industry level (failures and demands). The industry-average failure mode distribution (from Table 2) was sampled and the predicted number of events was evaluated using the binomial distribution with industry-average failure probability and associated number of demands. This process was repeated 1000 times, each time obtaining the total number of failures predicted by the industry average failure parameters. Then the actual number of observed unplanned demand failures (listed in the "Observed Failures" column of Table 10) was 
compared with this sample to determine the probability of observing this number of failures or greater. If the probability was greater than 0.05 and less than 0.95 , then the Table 2 industry-average distribution obtained from the ICES data analysis is considered to be consistent with the observed unplanned demand performance.

Table 10. EPS EDG unplanned demand performance comparison with industry-average performance from ICES data.

\begin{tabular}{ccccccc}
\hline $\begin{array}{c}\text { Failure } \\
\text { Modes }\end{array}$ & Plants & $\begin{array}{c}\text { Demands } \\
\text { or Hours }\end{array}$ & $\begin{array}{c}\text { Observed } \\
\text { Failures }\end{array}$ & $\begin{array}{c}\text { Expected } \\
\text { Failures }\end{array}$ & $\begin{array}{c}\text { Probability } \\
\text { of } \\
\text { 2 Failures }\end{array}$ & $\begin{array}{c}\text { Consistent with } \\
\text { Industry-Average } \\
\text { Performance? }\end{array}$ \\
\hline FTS & 95 & 534 & 0 & 1.5 & 1.00 & Yes $^{\text {a }}$ \\
FTLR & 95 & 311 & 1 & 1.2 & 0.64 & Yes \\
FTR & 95 & 4637 & 4 & 7.1 & 0.74 & Yes
\end{tabular}

a. In this case $P(X=0)=0.25$ which is considered consistent with the industry average data.

These consistency checks show that the FTS, FTLR, and FTR failure observations in the non-test, operational ESF demand data lie within their corresponding industry-average estimate distributions, provided in the 2015 Update (Table 2), that were based on both test and non-test operational ESF demands.

\subsection{EPS EDG Performance by Manufacturer}

Table 11 presents the results of summarizing EPS EDG performance by manufacturer. ICES contains information on EPS EDG manufacturers, but over the years some manufacturers have changed names or have been acquired by others. Therefore, in order to identify the original manufacturer, the ICES information was supplemented by other EPS EDG reports. The results are a second consistency check against the industry-average distributions in Table 2. The comparison was made for the combination of all three failure modes.

Two manufacturer's EPS EDG failure observations lie in the upper 95\% of the uncertainty range of the industry average distribution. However, these two manufacturers involve very few EPS EDGs. The rest of the manufacturers' failure observations lie within the $5 \%$ to $95 \%$ interval.

Table 11. EPS EDG manufacturer performance compared with industry-average performance-FTS, FTLR, and FTR $>1 H$ combined.

\begin{tabular}{|c|c|c|c|c|c|c|}
\hline Manufacturer & Code & $\begin{array}{l}\text { EPS } \\
\text { EDGs }\end{array}$ & $\begin{array}{l}\text { Observed } \\
\text { Failures }\end{array}$ & $\begin{array}{l}\text { Expected } \\
\text { Failures }\end{array}$ & $\begin{array}{l}\text { Probability } \\
\geq \text { Observed } \\
\text { Failures }\end{array}$ & $\begin{array}{l}\text { Consistent with } \\
\text { Industry-Average }^{\text {Performance? }^{\mathrm{a}}}\end{array}$ \\
\hline ALCO Power & AP & 24 & 69 & 88.4 & 0.74 & Yes \\
\hline Cooper Bessemer & CB & 37 & 75 & 135.5 & 0.93 & Yes \\
\hline $\begin{array}{l}\text { Electro Motive/General } \\
\text { Motors }\end{array}$ & EM/GM & 69 & 203 & 248.2 & 0.70 & Yes \\
\hline Fairbanks Morse/Colt & $\mathrm{FM} / \mathrm{C}$ & 67 & 250 & 250.2 & 0.46 & Yes \\
\hline Nordberg & NB & 8 & 37 & 36.5 & 0.44 & Yes \\
\hline $\begin{array}{l}\text { SAC/Compair Luchard/ } \\
\text { Jeumont Schndr }\end{array}$ & SC/JS & 3 & 22 & 9.6 & 0.02 & No \\
\hline TransAmerica DeLaval & TD & 20 & 84 & 78.3 & 0.36 & Yes \\
\hline Worthington Corp & WC & 4 & 37 & 12.6 & 0.00 & No \\
\hline
\end{tabular}


a. If the probability of observing the failures or greater is $\geq 0.05$ and $\leq 0.95$, then the industry-average estimate is considered consistent with the observed failure count.

\subsection{EPS EDG Performance by Rating}

Table 12 presents the results of the evaluation of EPS EDG performance by rating. The results are a consistency check of the industry-average distributions in Table 2 against observed performance by EDG rating. The comparison was made for the combination of all three failure modes. The failure observations for ratings all lie within the 5\% to $95 \%$ interval of the industry average distribution and are therefore consistent with the industry-average failure rate estimates.

Table 12. EPS EDG rating performance compared with industry-average performance-FTS, FTLR, and FTR $>1 H$ combined.

\begin{tabular}{lccccc}
\hline \multicolumn{1}{c}{ Rating } & $\begin{array}{c}\text { EPS } \\
\text { EDGs }\end{array}$ & $\begin{array}{c}\text { Observed } \\
\text { Failures }\end{array}$ & $\begin{array}{c}\text { Expected } \\
\text { Failures }\end{array}$ & $\begin{array}{c}\text { Probability } \\
\text { Observed } \\
\text { Failures }\end{array}$ & $\begin{array}{c}\text { Consistent with } \\
\text { Industry-Average } \\
\text { Performance? }\end{array}$ \\
\hline $450-249 \mathrm{KW}$ & 2 & 6 & 10.3 & 0.84 & Yes \\
$1,000-4,999 \mathrm{KW}$ & 170 & 576 & 631.3 & 0.57 & Yes \\
$5,000-99,999 \mathrm{KW}$ & 58 & 193 & 210.8 & 0.57 & Yes \\
$100,000-499,999 \mathrm{KW}$ & 2 & 2 & 4.8 & 0.92 & Yes \\
\hline $\begin{array}{l}\text { a. If the probability of observing the actual failures or greater is } \geq 0.05 \text { and } \leq 0.95 \text {, then the industry-average } \\
\text { estimate is considered consistent with the observed failure count. }\end{array}$ \\
\hline
\end{tabular}

\subsection{EPS EDG Engineering Analysis by Failure Modes}

The engineering analysis of EPS EDG failure sub-components, causes, detection methods, and recovery are presented in this section (There are too few HPCS EDGs to perform similar analyses on them). The events are also categorized by the failure mode determined after ICES data review by the INL staff. See Section 7 for more description of failure modes.

EPS EDG sub-component contributions to the three failure modes are presented in Figure 17. The sub-component contributions are similar to those used in the CCF database. For FTS, the instrumentation and control, generator, starting air, and engine piece parts are the top contributors to failures. For FTLR, the instrumentation and control and breaker are dominating contributors to failures. For FTR, high contributors include the cooling, engine, fuel oil, and instrumentation and control.

EPS EDG failure cause group contributions to the three failure modes are presented in Figure 18. The cause groups have been re-arranged in this update study in order to align with those currently used in the CCF database. Table 13 shows the breakdown of the cause groups with the specific causes that were coded during the data collection. The most likely causes are component issues and human errors. The Component cause group includes the causes that were related to something internal to the component or an aging or worn out part, which were categorized as the Internal cause group in previous studies [2]. The Human cause group is primarily influenced by maintenance and operating procedures and practices.

EPS EDG failure detection methods for the three failure modes are presented in Figure 19. The most likely detection method is testing, which is the prevalent detection method for most standby components. The inspection failure detection method is also important in the FTS failure mode. 
EPS EDG recovery results for the three failure modes are presented in Figure 20. Most EPS EDG failures were judged to not be recoverable. The overall non-recovery to recovery ratio is approximately $14: 1$, meaning that 14 of every 15 failures were not recovered.

Table 13. Component failure cause groups. ${ }^{a}$

\begin{tabular}{|c|c|c|}
\hline Group & Specific Cause & Description \\
\hline \multirow[t]{3}{*}{ Component } & $\begin{array}{l}\text { Internal to component, } \\
\text { piece-part }\end{array}$ & $\begin{array}{l}\text { Used when the cause of a failure is a non-specific result } \\
\text { of a failure internal to the component that failed other } \\
\text { than aging or wear. }\end{array}$ \\
\hline & Set point drift & $\begin{array}{l}\text { Used when the cause of a failure is the result of set } \\
\text { point drift or adjustment. }\end{array}$ \\
\hline & Age/Wear & $\begin{array}{l}\text { Used when the cause of the failure is a non-specific } \\
\text { aging or wear issue. }\end{array}$ \\
\hline \multirow[t]{3}{*}{ Design } & $\begin{array}{l}\text { Construction/installation } \\
\text { error or inadequacy }\end{array}$ & $\begin{array}{l}\text { Used when a construction or installation error is made } \\
\text { during the original or modification installation. This } \\
\text { includes specification of incorrect component or } \\
\text { material. }\end{array}$ \\
\hline & $\begin{array}{l}\text { Design error or } \\
\text { inadequacy }\end{array}$ & Used when a design error is made. \\
\hline & $\begin{array}{l}\text { Manufacturing error or } \\
\text { inadequacy }\end{array}$ & $\begin{array}{l}\text { Used when a manufacturing error is made during } \\
\text { component manufacture. }\end{array}$ \\
\hline \multirow[t]{3}{*}{ Environment } & $\begin{array}{l}\text { Ambient environmental } \\
\text { stress }\end{array}$ & $\begin{array}{l}\text { Used when the cause of a failure is the result of an } \\
\text { environmental condition from the location of the } \\
\text { component. }\end{array}$ \\
\hline & Internal environment & $\begin{array}{l}\text { The internal environment led to the failure. } \\
\text { Debris/Foreign material as well as an operating medium } \\
\text { chemistry issue. }\end{array}$ \\
\hline & $\begin{array}{l}\text { Extreme environmental } \\
\text { stress }\end{array}$ & $\begin{array}{l}\text { Used when the cause of a failure is the result of an } \\
\text { environmental condition that places a higher than } \\
\text { expected load on the equipment and is transitory in } \\
\text { nature. }\end{array}$ \\
\hline \multirow[t]{4}{*}{ Human } & $\begin{array}{l}\text { Accidental action } \\
\text { (unintentional or undesired } \\
\text { human errors) }\end{array}$ & $\begin{array}{l}\text { Used when a human error (during the performance of an } \\
\text { activity) results in an unintentional or undesired action. }\end{array}$ \\
\hline & Human action procedure & $\begin{array}{l}\text { Used when the correct procedure is not followed or the } \\
\text { wrong procedure is followed. For example: when a } \\
\text { missed step or incorrect step in a surveillance procedure } \\
\text { results in a component failure. }\end{array}$ \\
\hline & Inadequate maintenance & $\begin{array}{l}\text { Used when a human error (during the performance of } \\
\text { maintenance) results in an unintentional or undesired } \\
\text { action. }\end{array}$ \\
\hline & Inadequate procedure & $\begin{array}{l}\text { Used when the cause of a failure is the result of an } \\
\text { inadequate procedure operating or maintenance. }\end{array}$ \\
\hline \multirow[t]{2}{*}{ Other } & State of other component & $\begin{array}{l}\text { Used when the cause of a failure is the result of a } \\
\text { component state that is not associated with the } \\
\text { component that failed. An example would be the diesel } \\
\text { failed due to empty fuel storage tanks. }\end{array}$ \\
\hline & $\begin{array}{l}\text { Other (stated cause does } \\
\text { not fit other categories) }\end{array}$ & $\begin{array}{l}\text { Used when the cause of a failure is provided but it does } \\
\text { not meet any one of the descriptions. }\end{array}$ \\
\hline
\end{tabular}

${ }^{a}$. The cause groups have been re-arranged to align with those currently used in the CCF database. 

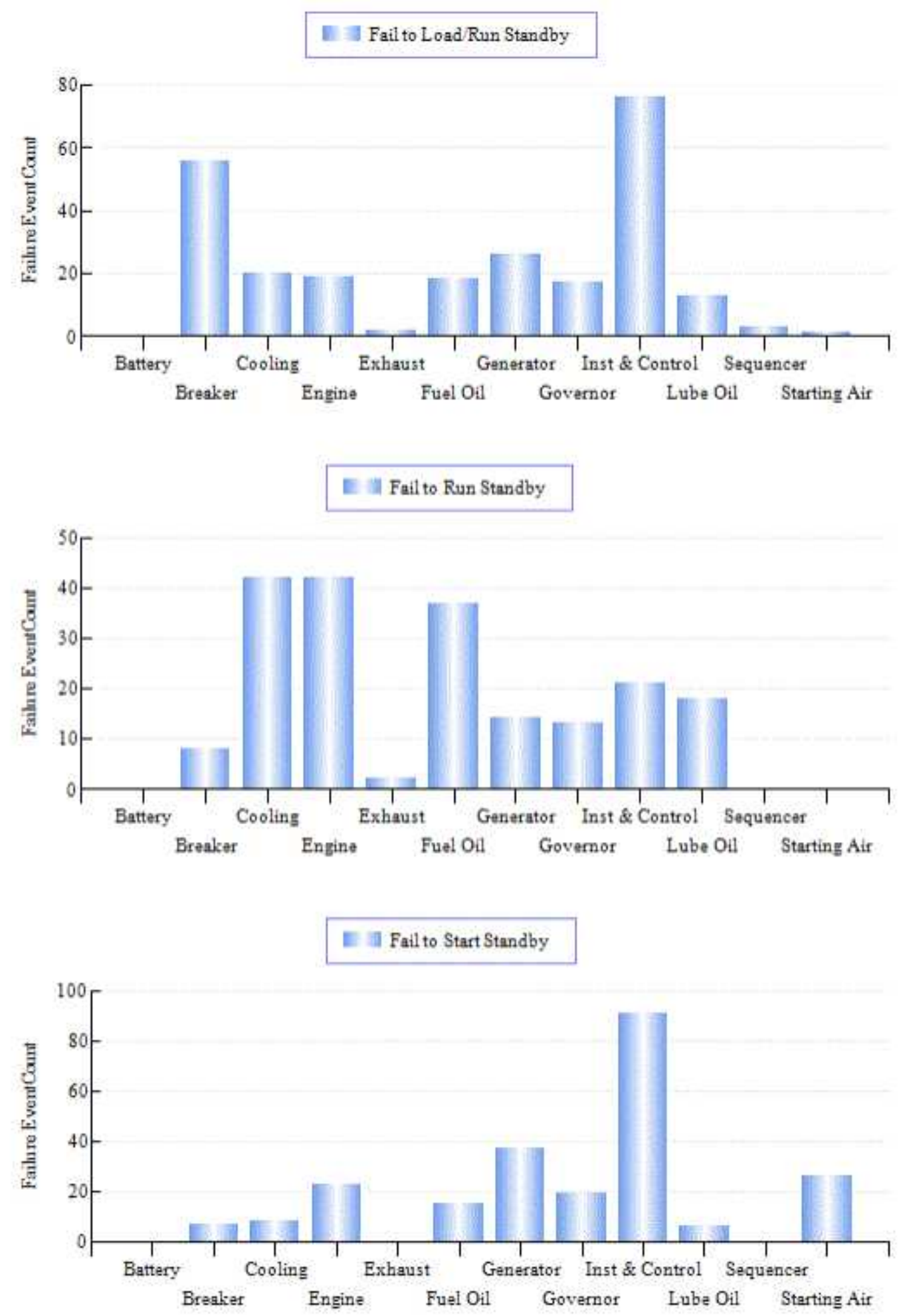

Figure 17. EPS EDG failure breakdown by sub component and failure mode 

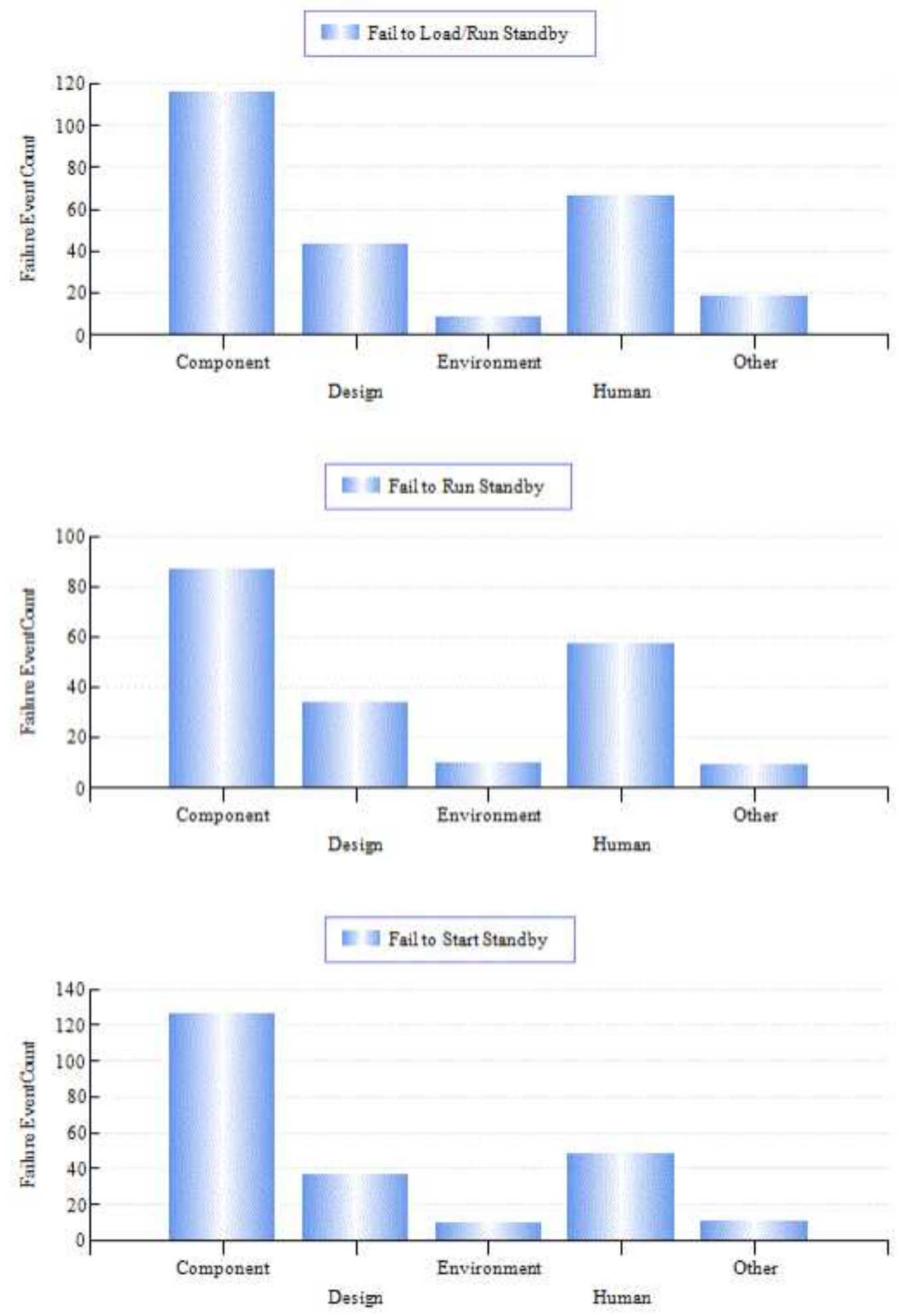

Figure 18. EPS EDG breakdown by cause group and failure mode 

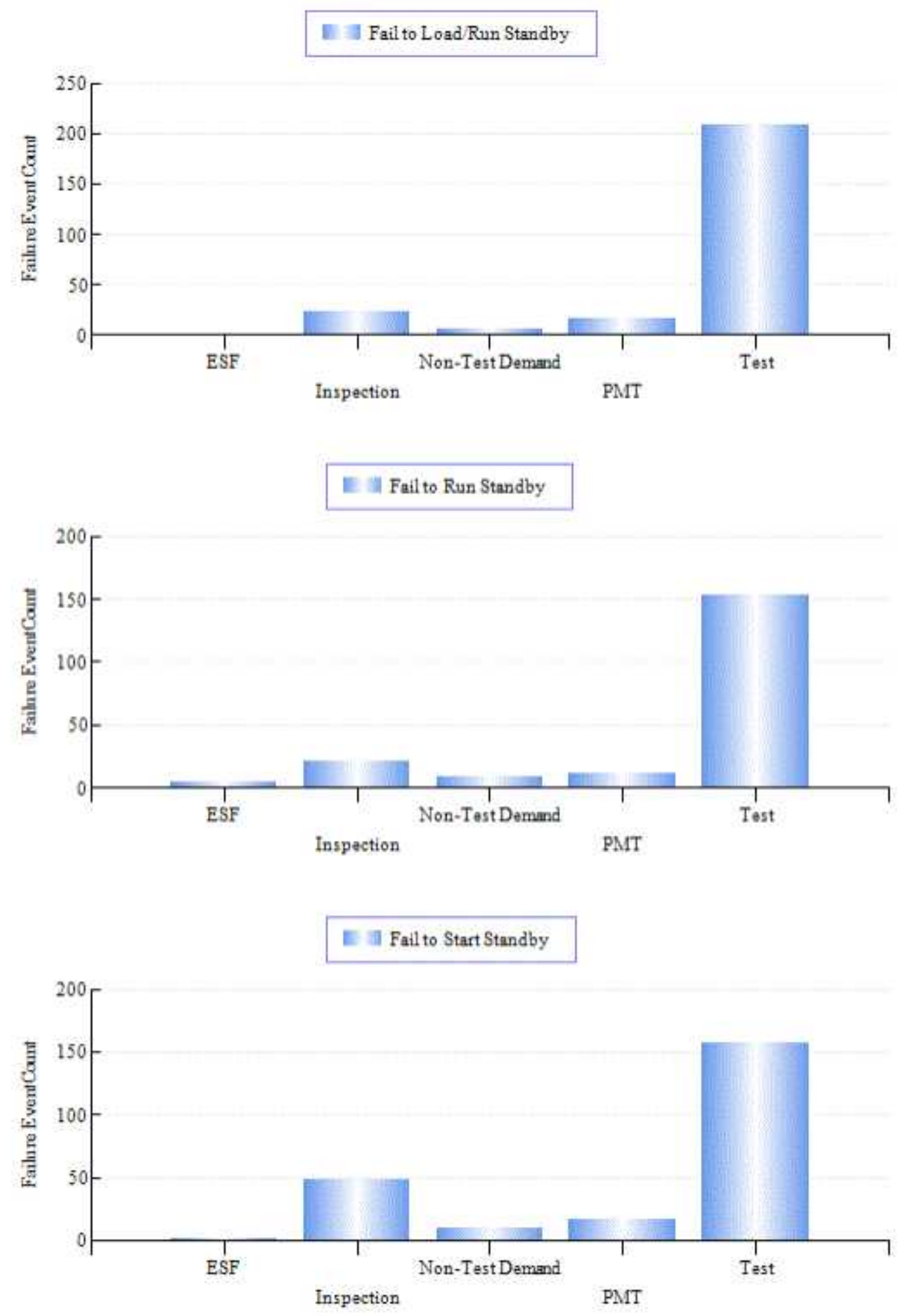

Figure 19. EPS EDG component failure distribution failure mode and method of detection 

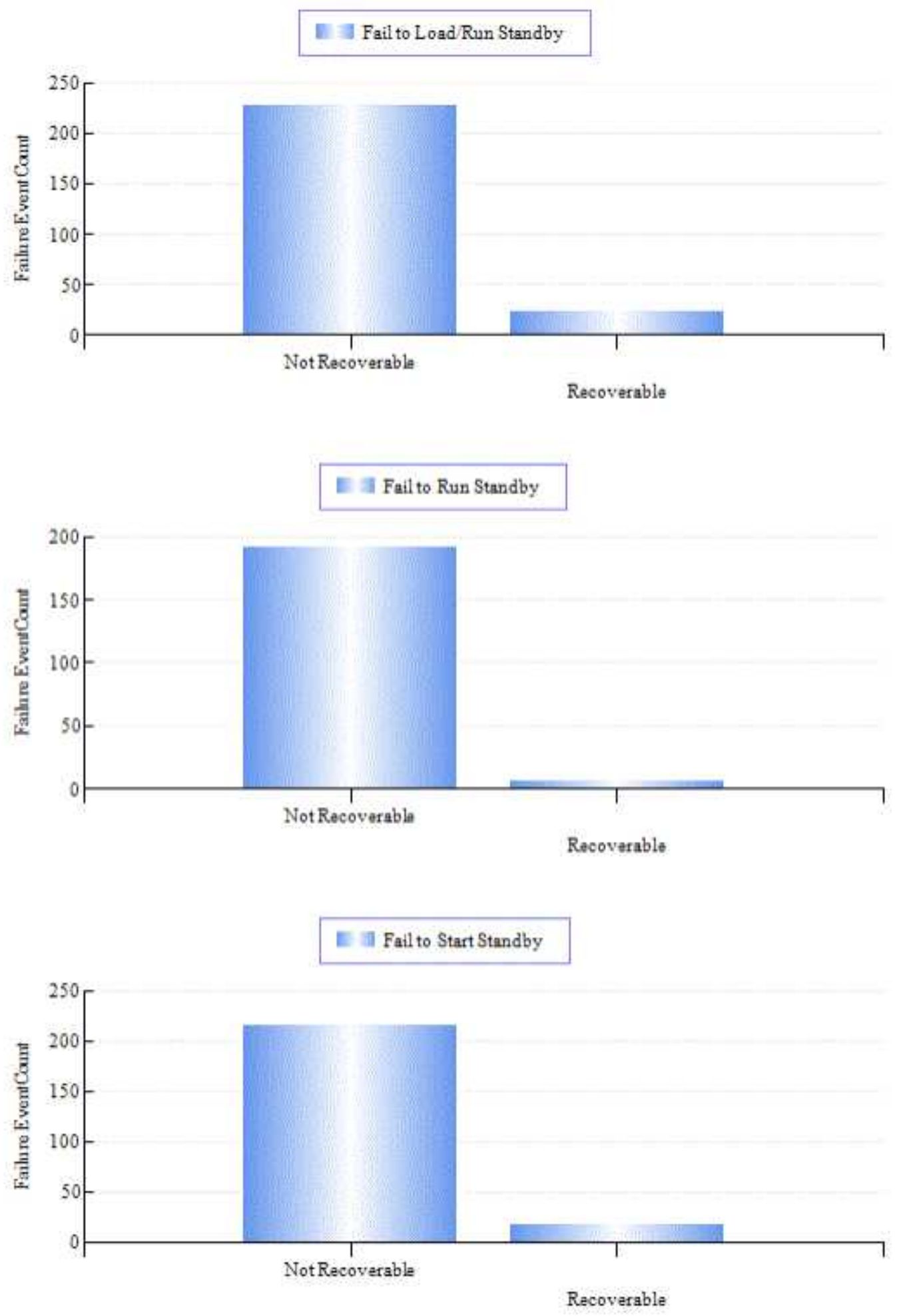

Figure 20. EPS EDG component failure distribution by failure mode and recovery determination 
Figure 21 shows the percentage of failure events for the three failure modes segregated by EPS EDG manufacturer as indicated in the ICES database. Table 14 shows the distribution of the various manufacturers of EPS EDGs in the ICES database and the total failure count associated with each. Based on the information given in Figure 21, EPS EDG manufacturers do not appear to be correlated to any particular failure mode pattern.

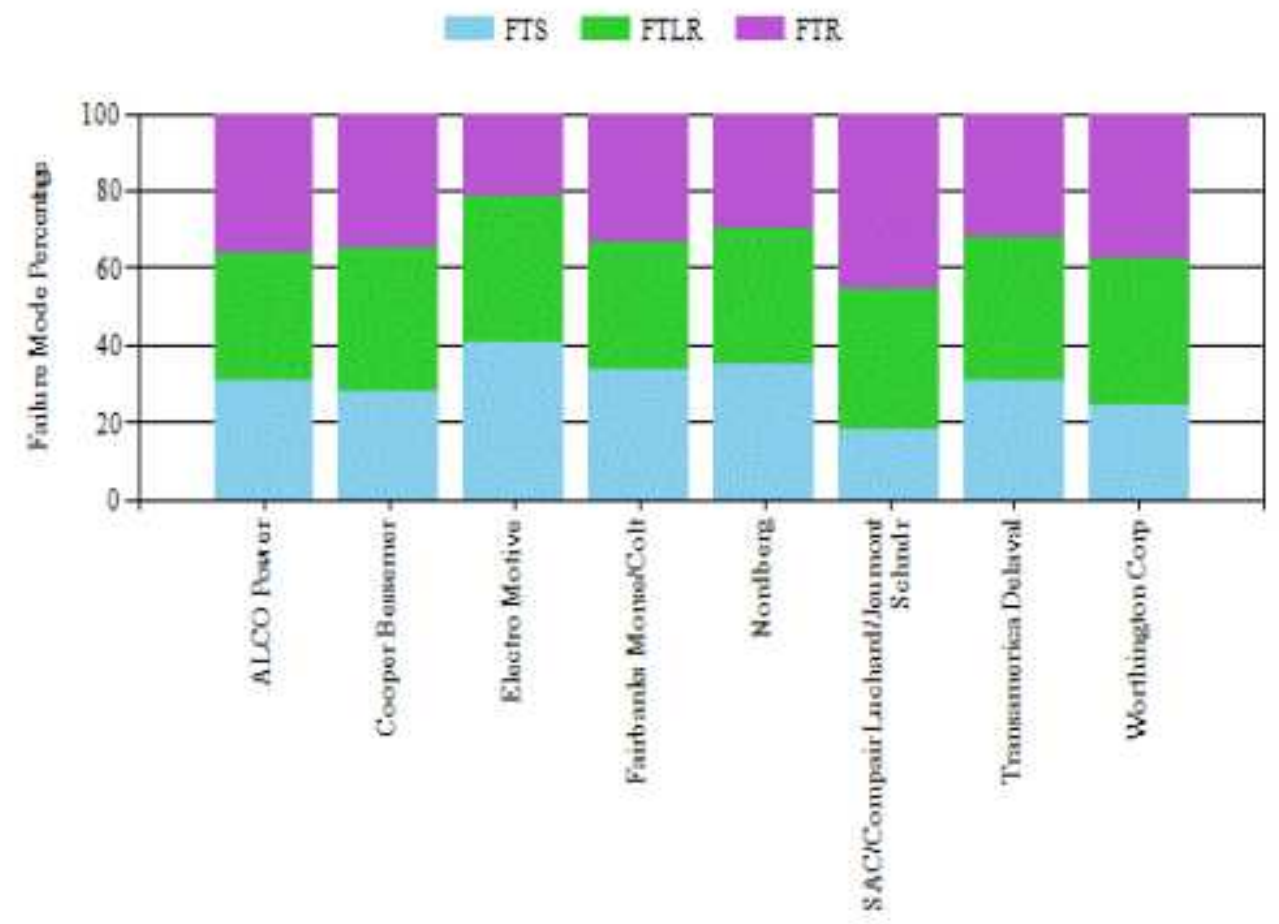

Figure 21. EPS EDG failure distribution by manufacturer

Table 14. EPS EDG manufacturer population and total failure count.

\begin{tabular}{lccccc}
\hline \multicolumn{1}{c}{ Manufacturer } & Code & $\begin{array}{c}\text { EPS } \\
\text { EDGs }\end{array}$ & $\begin{array}{c}\text { \% of } \\
\text { EDGs }\end{array}$ & $\begin{array}{c}\text { Total } \\
\text { Failure } \\
\text { Count }\end{array}$ & $\begin{array}{c}\text { \% of } \\
\text { Failures }\end{array}$ \\
\hline ALCO Power & AP & 24 & $10.3 \%$ & 69 & $8.9 \%$ \\
Cooper Bessemer & CB & 37 & $15.9 \%$ & 75 & $9.7 \%$ \\
Electro Motive & EM/GM & 69 & $29.7 \%$ & 203 & $26.1 \%$ \\
\hline Fairbanks Morse/Colt & FM/C & 67 & $28.9 \%$ & 250 & $32.2 \%$ \\
Nordberg & NB & 8 & $3.4 \%$ & 37 & $4.8 \%$ \\
SAC/Compair Luchard/Jeumont Schndr & SC/JS & 3 & $1.3 \%$ & 22 & $2.8 \%$ \\
Transamerica Delaval & TD & 20 & $8.6 \%$ & 84 & $10.8 \%$ \\
Worthington Corp & WC & 4 & $1.7 \%$ & 37 & $4.8 \%$ \\
Totals & & 232 & $100 \%$ & 777 & $100 \%$ \\
\hline
\end{tabular}


Figure 22 shows the percentage of failure events for the three failure modes segregated by EPS EDG rating as indicated in the ICES database. Table 15 shows the distribution of the various rated EPS EDGs in the ICES database used in this study. The larger EDG differs from the others in not yet having any FTS events, but the operational experience for this EDG is much shorter than for other EDGs.

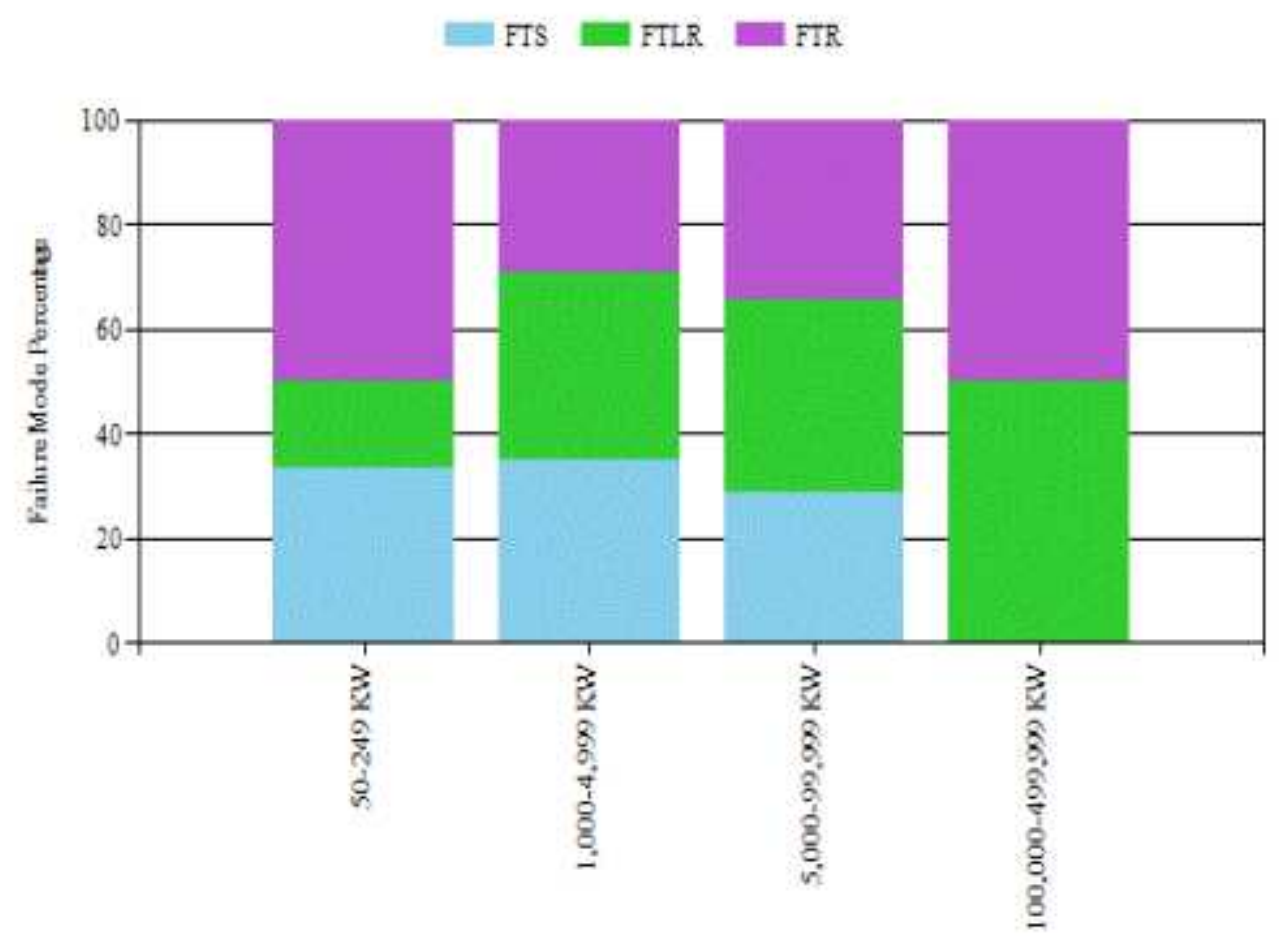

Figure 22. EPS EDG component failure modes by EPS EDG rating

Table 15. EPS EDG population by rating.

\begin{tabular}{lcccc}
\hline \multicolumn{1}{c}{ EPS EDG Rating } & $\begin{array}{c}\text { Device } \\
\text { Count }\end{array}$ & $\begin{array}{c}\% \text { of } \\
\text { Devices }\end{array}$ & $\begin{array}{c}\text { Total } \\
\text { Failure } \\
\text { Count }\end{array}$ & $\begin{array}{c}\% \text { of } \\
\text { Failures }\end{array}$ \\
\hline $50-249 \mathrm{KW}$ & 2 & $0.9 \%$ & 6 & $0.8 \%$ \\
$1,000-4,999 \mathrm{KW}$ & 170 & $73.3 \%$ & 576 & $74.1 \%$ \\
$5,000-99,999 \mathrm{KW}$ & 58 & $25.0 \%$ & 193 & $24.8 \%$ \\
$100,000-499,999 \mathrm{KW}$ & 2 & $0.9 \%$ & 2 & $0.3 \%$ \\
Total & 232 & $100 \%$ & 777 & $100 \%$ \\
\hline
\end{tabular}




\section{EPS EDG ASSEMBLY DESCRIPTION}

The EDGs are those within the Class 1E ac electrical power system at U.S. commercial nuclear power plants and those in the HPCS systems. Station blackout EDGs are not included.

The EDG includes the diesel engine with all components in the exhaust path, electrical generator, generator exciter, output breaker, combustion air, lube oil systems, fuel oil system, and starting compressed air system, and local instrumentation and control circuitry. The sequencer is excluded from the EDG component. For the service water system providing cooling to the EDGs, only the devices providing control of cooling flow to the EDG heat exchangers are included. Room heating and ventilating is not included.

The EDG failure modes include FTS, FTLR, and FTR $>1 \mathrm{H}$. These failure modes were used in NUREG/CR-6928 and are similar to those used in the MSPI Program. There is some uncertainty concerning when the run hours should start to be counted; for example, should they start as soon as the EDG starts or should they start only after the output circuit breaker has closed? For this study, the run hours start as soon as the EDG is started, which is the way data have been reported in ICES. The total run hours are partitioned by failure mode, with the first hour being used for FTLR, and the remaining hours assigned to FTR $>1 \mathrm{H}$.

Guidelines for determining whether a component failure event reported in ICES is to be included in FTS, FTLR, or FTR $>1 \mathrm{H}$ are similar to those used in the MSPI Program. In general, any circumstance in which the component is not able to meet the performance requirements defined in the PRA is counted. This includes conditions revealed through testing, operational demands, unplanned demands, or discovery (see INPO 12-009 [9] for examples of operational demands, or operational non-test demands). Also, run failures that occur beyond the typical 24-hour mission time in PRAs are included. However, certain events are excluded: slow engine starting times that do not exceed the PRA success criteria, conditions that are annunciated immediately in the control room without a demand, and run events representing degraded conditions that are shown to not have caused an actual run failure within 24 hours. Also, events occurring during maintenance or post-maintenance testing that are related to the actual maintenance activities are excluded. Finally, in contrast to the MSPI Program, a general guideline on slow starting times is to include only those slow starts requiring more than 20 seconds as FTS events, similar to what was done for the CCF database and the EPS system study. (In the MSPI Program, most licensees chose to use technical specification requirements for fast starts as their success criteria - typically less than 10 seconds to start.) All of the EDG events within ICES were reviewed to ensure that they were binned to the correct failure mode-FTS, FTLR, FTR $>1 \mathrm{H}$, or no failure. However, even given detailed descriptions of failure events, this binning still required some judgment and involves some uncertainty.

Guidelines for counting demands and run hours are similar to those in the MSPI Program. Start and load/run demands include those resulting from tests, operational demands, and unplanned demands. Demands during maintenance and post-maintenance testing are excluded. Similarly, run hours include those from tests, operational demands, and unplanned demands. Note that the test demands and run hours dominate the totals, compared with operational and unplanned demands and run hours. 


\section{DATA TABLES}

In this section, the plot data for Figure 1 to Figure 16 in previous sections are provided in Table 16 to Table 31 , respectively.

\begin{tabular}{ccl}
\hline Figure & Table & \multicolumn{1}{c}{ Analysis } \\
\hline Figure 1 & Table 16 & Failure probability estimate trend for EPS EDG FTS \\
\hline Figure 2 & Table 17 & Failure probability estimate trend for EPS EDG FTLR \\
\hline Figure 3 & Table 18 & Failure rate estimate trend for EPS EDG FTR $>$ 1H \\
\hline Figure 4 & Table 19 & Failure probability estimate trend for HPCS EDG FTS \\
\hline Figure 5 & Table 20 & Failure probability estimate trend for HPCS EDG FTLR \\
\hline Figure 6 & Table 21 & Failure rate estimate trend for HPCS EDG FTR>1H \\
\hline Figure 7 & Table 22 & EPS EDG UA trend \\
\hline Figure 8 & Table 23 & HPCS EDG UA trend \\
\hline Figure 9 & Table 24 & EPS EDG unreliability trend (8-hour mission) \\
\hline Figure 10 & Table 25 & HPCS EDG unreliability trend (8-hour mission) \\
\hline Figure 11 & Table 26 & Frequency of start demands (demands per reactor year) trendfor EPS and HPCS EDGs \\
\hline Figure 12 & Table 27 & Frequency of FTLR demands (demands per reactor year) trend for EPS and HPCS EDGs \\
\hline Figure 13 & Table 28 & Frequency of run $>$ 1H hours (hours per reactor year) trend for EPS and HPCS EDG \\
\hline Figure 14 & Table 29 & Frequency of FTS events (events per reactor year) trend for EPS and HPCS EDGs \\
\hline Figure 15 & Table 30 & Frequency of FTLR events (events per reactor year) trend for EPS and HPCS EDGs \\
\hline Figure 16 & Table 31 & Frequency of FTR>1H events (events per reactor year) trend for EPS and HPCS EDGs \\
\hline
\end{tabular}


Table 16. Plot data for Figure 1, failure probability estimate trend for EPS EDG FTS

\begin{tabular}{|c|c|c|c|c|c|c|c|c|}
\hline \multirow[b]{2}{*}{ Year } & \multirow[b]{2}{*}{ Failures } & \multirow[b]{2}{*}{ Demands } & \multicolumn{3}{|c|}{ Regression Curve Data Points } & \multicolumn{3}{|c|}{ Plot Trend Error Bar Points } \\
\hline & & & Mean & $\begin{array}{c}\text { Lower } \\
(5 \%)\end{array}$ & $\begin{array}{l}\text { Upper } \\
(95 \%)\end{array}$ & $\begin{array}{l}\text { Lower } \\
(5 \%)\end{array}$ & $\begin{array}{l}\text { Upper } \\
(95 \%)\end{array}$ & Mean \\
\hline \multicolumn{2}{|c|}{2015 Update } & & & & & 1.45E-03 & $4.59 \mathrm{E}-03$ & $2.83 \mathrm{E}-03$ \\
\hline 1998 & 18 & 4,285 & -- & -- & -- & 2.71E-03 & $6.13 \mathrm{E}-03$ & 4.16E-03 \\
\hline 1999 & 8 & 4,168 & -- & -- & -- & 1.00E-03 & $3.48 \mathrm{E}-03$ & $1.96 \mathrm{E}-03$ \\
\hline 2000 & 12 & 3,909 & -- & -- & -- & 1.79E-03 & 4.92E-03 & 3.07E-03 \\
\hline 2001 & 12 & 4,023 & -- & -- & -- & 1.75E-03 & 4.79E-03 & $2.99 \mathrm{E}-03$ \\
\hline 2002 & 10 & 4,272 & -- & -- & -- & $1.31 \mathrm{E}-03$ & $3.96 \mathrm{E}-03$ & $2.37 \mathrm{E}-03$ \\
\hline 2003 & 17 & 4,329 & - & -- & -- & 2.50E-03 & $5.80 \mathrm{E}-03$ & $3.90 \mathrm{E}-03$ \\
\hline 2004 & 14 & 4,338 & -- & -- & -- & 1.97E-03 & 4.99E-03 & $3.22 \mathrm{E}-03$ \\
\hline 2005 & 16 & 4,383 & -- & -- & -- & $2.30 \mathrm{E}-03$ & $5.47 \mathrm{E}-03$ & 3.63E-03 \\
\hline 2006 & 9 & 4,371 & -- & -- & -- & 1.12E-03 & $3.60 \mathrm{E}-03$ & 2.09E-03 \\
\hline 2007 & 11 & 4,288 & -- & -- & -- & 1.47E-03 & 4.23E-03 & $2.58 \mathrm{E}-03$ \\
\hline 2008 & 8 & 4,331 & -- & -- & -- & $9.65 \mathrm{E}-04$ & 3.35E-03 & $1.89 \mathrm{E}-03$ \\
\hline 2009 & 15 & 4,224 & $3.79 \mathrm{E}-03$ & $2.53 \mathrm{E}-03$ & $5.68 \mathrm{E}-03$ & $2.20 \mathrm{E}-03$ & $5.40 \mathrm{E}-03$ & 3.53E-03 \\
\hline 2010 & 15 & 4,091 & $3.57 \mathrm{E}-03$ & $2.54 \mathrm{E}-03$ & $5.02 \mathrm{E}-03$ & 2.27E-03 & $5.57 \mathrm{E}-03$ & 3.64E-03 \\
\hline 2011 & 19 & 4,127 & 3.37E-03 & $2.53 \mathrm{E}-03$ & 4.49E-03 & 3.00E-03 & $6.63 \mathrm{E}-03$ & $4.55 \mathrm{E}-03$ \\
\hline 2012 & 14 & 4,035 & $3.18 \mathrm{E}-03$ & $2.48 \mathrm{E}-03$ & 4.07E-03 & 2.11E-03 & $5.35 \mathrm{E}-03$ & 3.45E-03 \\
\hline 2013 & 6 & 4,103 & $2.99 \mathrm{E}-03$ & $2.37 \mathrm{E}-03$ & $3.78 \mathrm{E}-03$ & 6.91E-04 & 2.93E-03 & $1.52 \mathrm{E}-03$ \\
\hline 2014 & 12 & 4,081 & $2.82 \mathrm{E}-03$ & $2.20 \mathrm{E}-03$ & $3.62 \mathrm{E}-03$ & 1.72E-03 & 4.72E-03 & $2.95 \mathrm{E}-03$ \\
\hline 2015 & 13 & 4,022 & $2.66 \mathrm{E}-03$ & 2.00E-03 & $3.54 \mathrm{E}-03$ & 1.93E-03 & $5.08 \mathrm{E}-03$ & $3.23 \mathrm{E}-03$ \\
\hline 2016 & 13 & 4,039 & $2.51 \mathrm{E}-03$ & $1.79 \mathrm{E}-03$ & $3.52 \mathrm{E}-03$ & 1.92E-03 & $5.06 \mathrm{E}-03$ & $3.21 \mathrm{E}-03$ \\
\hline 2017 & 10 & 3,987 & $2.36 \mathrm{E}-03$ & $1.58 \mathrm{E}-03$ & $3.54 \mathrm{E}-03$ & 1.40E-03 & 4.23E-03 & $2.53 \mathrm{E}-03$ \\
\hline 2018 & 7 & 3,957 & $2.23 \mathrm{E}-03$ & $1.39 \mathrm{E}-03$ & 3.57E-03 & 8.81E-04 & 3.35E-03 & $1.82 \mathrm{E}-03$ \\
\hline Total & 259 & 87,362 & & & & & & \\
\hline
\end{tabular}


Table 17. Plot data for Figure 2, failure probability estimate trend for EPS EDG FTLR

\begin{tabular}{|c|c|c|c|c|c|c|c|c|}
\hline \multirow[b]{2}{*}{ Year } & \multirow[b]{2}{*}{ Failures } & \multirow[b]{2}{*}{ Demands } & \multicolumn{3}{|c|}{ Regression Curve Data Points } & \multicolumn{3}{|c|}{ Plot Trend Error Bar Points } \\
\hline & & & Mean & $\begin{array}{c}\text { Lower } \\
(5 \%)\end{array}$ & $\begin{array}{l}\text { Upper } \\
(95 \%)\end{array}$ & $\begin{array}{c}\text { Lower } \\
(5 \%)\end{array}$ & $\begin{array}{l}\text { Upper } \\
(95 \%)\end{array}$ & Mean \\
\hline \multicolumn{2}{|c|}{2015 Update } & & & & & 1.18E-03 & 7.42E-03 & 3.73E-03 \\
\hline 1998 & 14 & 3,688 & -- & -- & -- & 2.32E-03 & $5.88 \mathrm{E}-03$ & 3.79E-03 \\
\hline 1999 & 5 & 3,648 & -- & -- & -- & 6.05E-04 & 2.95E-03 & 1.45E-03 \\
\hline 2000 & 8 & 3,585 & -- & -- & -- & 1.17E-03 & 4.05E-03 & $2.29 \mathrm{E}-03$ \\
\hline 2001 & 13 & 3,715 & -- & -- & -- & 2.10E-03 & $5.52 \mathrm{E}-03$ & $3.51 \mathrm{E}-03$ \\
\hline 2002 & 14 & 3,638 & -- & -- & -- & 2.35E-03 & 5.96E-03 & 3.84E-03 \\
\hline 2003 & 15 & 3,790 & -- & -- & -- & $2.46 \mathrm{E}-03$ & 6.03E-03 & 3.95E-03 \\
\hline 2004 & 10 & 3,822 & -- & -- & -- & 1.47E-03 & 4.44E-03 & 2.65E-03 \\
\hline 2005 & 15 & 3,784 & -- & -- & -- & 2.46E-03 & 6.04E-03 & 3.96E-03 \\
\hline 2006 & 15 & 3,757 & -- & -- & -- & 2.48E-03 & 6.08E-03 & 3.98E-03 \\
\hline 2007 & 21 & 3,645 & -- & -- & -- & 3.83E-03 & 8.15E-03 & 5.69E-03 \\
\hline 2008 & 16 & 3,729 & -- & -- & -- & $2.70 \mathrm{E}-03$ & 6.44E-03 & 4.27E-03 \\
\hline 2009 & 18 & 3,668 & 4.30E-03 & 3.35E-03 & 5.51E-03 & 3.17E-03 & 7.17E-03 & 4.87E-03 \\
\hline 2010 & 11 & 3,571 & 4.14E-03 & 3.36E-03 & $5.11 \mathrm{E}-03$ & 1.77E-03 & 5.08E-03 & $3.10 \mathrm{E}-03$ \\
\hline 2011 & 16 & 3,605 & 3.99E-03 & 3.35E-03 & 4.76E-03 & $2.79 \mathrm{E}-03$ & 6.65E-03 & 4.41E-03 \\
\hline 2012 & 17 & 3,569 & 3.84E-03 & 3.30E-03 & 4.47E-03 & 3.04E-03 & 7.04E-03 & 4.73E-03 \\
\hline 2013 & 12 & 3,577 & 3.70E-03 & $3.22 \mathrm{E}-03$ & $4.26 \mathrm{E}-03$ & 1.97E-03 & 5.40E-03 & 3.37E-03 \\
\hline 2014 & 12 & 3,603 & 3.57E-03 & 3.08E-03 & 4.13E-03 & 1.96E-03 & 5.36E-03 & 3.34E-03 \\
\hline 2015 & 13 & 3,534 & $3.44 \mathrm{E}-03$ & 2.91E-03 & 4.06E-03 & $2.20 \mathrm{E}-03$ & 5.79E-03 & $3.68 \mathrm{E}-03$ \\
\hline 2016 & 11 & 3,527 & 3.31E-03 & $2.72 \mathrm{E}-03$ & 4.03E-03 & 1.79E-03 & 5.14E-03 & $3.14 \mathrm{E}-03$ \\
\hline 2017 & 9 & 3,484 & 3.19E-03 & 2.53E-03 & 4.03E-03 & $1.40 \mathrm{E}-03$ & 4.51E-03 & 2.63E-03 \\
\hline 2018 & 13 & 3,484 & 3.07E-03 & 2.34E-03 & 4.04E-03 & 2.23E-03 & 5.87E-03 & $3.73 \mathrm{E}-03$ \\
\hline Total & 278 & 76,422 & & & & & & \\
\hline
\end{tabular}


Table 18. Plot data for Figure 3, failure rate estimate trend for EPS EDG FTR $>1 \mathrm{H}$

\begin{tabular}{|c|c|c|c|c|c|c|c|c|}
\hline \multirow[b]{2}{*}{ Year } & \multirow[b]{2}{*}{ Failures } & \multirow[b]{2}{*}{$\begin{array}{c}\text { Run Time } \\
\text { (hr) }\end{array}$} & \multicolumn{3}{|c|}{ Regression Curve Data Points } & \multicolumn{3}{|c|}{ Plot Trend Error Bar Points } \\
\hline & & & Mean & $\begin{array}{l}\text { Lower } \\
(5 \%)\end{array}$ & $\begin{array}{l}\text { Upper } \\
(95 \%)\end{array}$ & $\begin{array}{l}\text { Lower } \\
(5 \%)\end{array}$ & $\begin{array}{l}\text { Upper } \\
(95 \%)\end{array}$ & Mean \\
\hline \multicolumn{2}{|c|}{2015 Update } & & & & & $3.78 \mathrm{E}-04$ & 3.34E-03 & $1.54 \mathrm{E}-03$ \\
\hline 1998 & 4 & 10,000 & -- & -- & -- & $1.61 \mathrm{E}-04$ & 9.55E-04 & 4.37E-04 \\
\hline 1999 & 1 & 10,319 & -- & -- & -- & $1.66 \mathrm{E}-05$ & 5.21E-04 & 1.41E-04 \\
\hline 2000 & 7 & 11,538 & -- & -- & -- & 3.07E-04 & 1.16E-03 & 6.33E-04 \\
\hline 2001 & 2 & 11,977 & -- & -- & -- & 4.66E-05 & 5.73E-04 & 2.04E-04 \\
\hline 2002 & 7 & 12,341 & -- & -- & -- & 2.87E-04 & 1.09E-03 & 5.93E-04 \\
\hline 2003 & 10 & 11,699 & -- & -- & -- & 4.83E-04 & 1.47E-03 & 8.75E-04 \\
\hline 2004 & 13 & 11,747 & -- & -- & -- & 6.70E-04 & 1.77E-03 & 1.12E-03 \\
\hline 2005 & 14 & 12,307 & -- & -- & -- & 7.02E-04 & 1.78E-03 & 1.15E-03 \\
\hline 2006 & 4 & 11,369 & -- & -- & -- & $1.42 \mathrm{E}-04$ & 8.43E-04 & 3.86E-04 \\
\hline 2007 & 17 & 11,365 & -- & -- & -- & 9.63E-04 & 2.24E-03 & $1.50 \mathrm{E}-03$ \\
\hline 2008 & 20 & 11,238 & -- & -- & -- & 1.18E-03 & 2.57E-03 & 1.78E-03 \\
\hline 2009 & 8 & 11,223 & $1.21 \mathrm{E}-03$ & 7.09E-04 & 2.06E-03 & 3.76E-04 & 1.31E-03 & 7.37E-04 \\
\hline 2010 & 13 & 10,777 & $1.28 \mathrm{E}-03$ & 8.14E-04 & 2.02E-03 & 7.29E-04 & 1.92E-03 & $1.22 \mathrm{E}-03$ \\
\hline 2011 & 21 & 11,810 & 1.36E-03 & $9.26 \mathrm{E}-04$ & 2.00E-03 & 1.20E-03 & 2.54E-03 & 1.77E-03 \\
\hline 2012 & 11 & 7,257 & $1.44 \mathrm{E}-03$ & $1.04 \mathrm{E}-03$ & 2.00E-03 & 8.66E-04 & 2.49E-03 & 1.52E-03 \\
\hline 2013 & 17 & 7,796 & 1.53E-03 & 1.14E-03 & 2.06E-03 & 1.39E-03 & 3.22E-03 & 2.16E-03 \\
\hline 2014 & 17 & 7,133 & $1.62 \mathrm{E}-03$ & $1.21 \mathrm{E}-03$ & 2.18E-03 & $1.51 \mathrm{E}-03$ & 3.51E-03 & $2.35 \mathrm{E}-03$ \\
\hline 2015 & 12 & 7,614 & $1.72 \mathrm{E}-03$ & $1.24 \mathrm{E}-03$ & 2.38E-03 & 9.23E-04 & 2.53E-03 & 1.58E-03 \\
\hline 2016 & 10 & 7,425 & 1.82E-03 & $1.25 \mathrm{E}-03$ & 2.66E-03 & 7.50E-04 & 2.28E-03 & 1.36E-03 \\
\hline 2017 & 22 & 7,223 & 1.93E-03 & $1.24 \mathrm{E}-03$ & 3.02E-03 & 2.03E-03 & 4.25E-03 & 2.99E-03 \\
\hline 2018 & 10 & 7,670 & $2.05 \mathrm{E}-03$ & $1.21 \mathrm{E}-03$ & 3.46E-03 & 7.27E-04 & $2.21 \mathrm{E}-03$ & 1.32E-03 \\
\hline Total & 240 & 211,828 & & & & & & \\
\hline
\end{tabular}


Table 19. Plot data for Figure 4, failure probability estimate trend for HPCS EDG FTS

\begin{tabular}{|c|c|c|c|c|c|c|c|c|}
\hline \multirow[b]{2}{*}{ Year } & \multirow[b]{2}{*}{ Failures } & \multirow[b]{2}{*}{ Demands } & \multicolumn{3}{|c|}{ Regression Curve Data Points } & \multicolumn{3}{|c|}{ Plot Trend Error Bar Points } \\
\hline & & & Mean & $\begin{array}{c}\text { Lower } \\
(5 \%)\end{array}$ & $\begin{array}{l}\text { Upper } \\
(95 \%)\end{array}$ & $\begin{array}{c}\text { Lower } \\
(5 \%)\end{array}$ & $\begin{array}{l}\text { Upper } \\
(95 \%)\end{array}$ & Mean \\
\hline \multicolumn{2}{|c|}{2015 Update } & & & & & 2.19E-04 & 2.12E-03 & 9.56E-04 \\
\hline 1998 & 0 & 151 & -- & -- & -- & 4.51E-06 & 8.94E-03 & 1.15E-03 \\
\hline 1999 & 1 & 187 & -- & -- & -- & 3.73E-04 & 1.17E-02 & $3.18 \mathrm{E}-03$ \\
\hline 2000 & 0 & 145 & -- & -- & -- & 4.58E-06 & 9.06E-03 & 1.16E-03 \\
\hline 2001 & 0 & 154 & -- & -- & -- & 4.48E-06 & 8.88E-03 & $1.14 \mathrm{E}-03$ \\
\hline 2002 & 0 & 140 & -- & -- & -- & 4.62E-06 & 9.16E-03 & 1.18E-03 \\
\hline 2003 & 0 & 152 & -- & -- & -- & 4.50E-06 & 8.91E-03 & $1.14 \mathrm{E}-03$ \\
\hline 2004 & 0 & 139 & -- & -- & -- & 4.63E-06 & 9.17E-03 & 1.18E-03 \\
\hline 2005 & 0 & 133 & -- & -- & -- & 4.70E-06 & $9.31 \mathrm{E}-03$ & $1.20 \mathrm{E}-03$ \\
\hline 2006 & 0 & 136 & -- & -- & -- & 4.66E-06 & 9.24E-03 & 1.19E-03 \\
\hline 2007 & 0 & 126 & -- & -- & -- & 4.79E-06 & $9.48 \mathrm{E}-03$ & $1.22 \mathrm{E}-03$ \\
\hline 2008 & 1 & 152 & -- & -- & -- & 4.03E-04 & 1.26E-02 & $3.44 \mathrm{E}-03$ \\
\hline 2009 & 0 & 138 & 1.08E-03 & 5.87E-04 & 2.00E-03 & 4.65E-06 & $9.20 \mathrm{E}-03$ & 1.18E-03 \\
\hline 2010 & 0 & 151 & 1.16E-03 & $6.89 \mathrm{E}-04$ & 1.95E-03 & 4.51E-06 & 8.93E-03 & 1.15E-03 \\
\hline 2011 & 0 & 152 & 1.24E-03 & 8.00E-04 & 1.92E-03 & 4.50E-06 & 8.91E-03 & $1.14 \mathrm{E}-03$ \\
\hline 2012 & 0 & 128 & 1.32E-03 & $9.10 \mathrm{E}-04$ & $1.92 E-03$ & 4.76E-06 & $9.43 \mathrm{E}-03$ & $1.21 \mathrm{E}-03$ \\
\hline 2013 & 0 & 158 & 1.41E-03 & 1.00E-03 & 1.99E-03 & 4.44E-06 & 8.80E-03 & 1.13E-03 \\
\hline 2014 & 1 & 136 & $1.51 \mathrm{E}-03$ & 1.06E-03 & $2.15 \mathrm{E}-03$ & 4.19E-04 & 1.31E-02 & 3.57E-03 \\
\hline 2015 & 0 & 140 & 1.61E-03 & 1.08E-03 & 2.41E-03 & 4.63E-06 & 9.17E-03 & 1.18E-03 \\
\hline 2016 & 0 & 138 & 1.73E-03 & 1.08E-03 & 2.77E-03 & 4.65E-06 & $9.21 \mathrm{E}-03$ & 1.18E-03 \\
\hline 2017 & 0 & 139 & 1.84E-03 & 1.05E-03 & 3.23E-03 & 4.64E-06 & $9.19 \mathrm{E}-03$ & $1.18 \mathrm{E}-03$ \\
\hline 2018 & 1 & 144 & 1.97E-03 & $1.02 \mathrm{E}-03$ & 3.80E-03 & 4.11E-04 & 1.29E-02 & $3.50 \mathrm{E}-03$ \\
\hline Total & 4 & 3,038 & & & & & & \\
\hline
\end{tabular}


Table 20. Plot data for Figure 5, failure probability estimate trend for HPCS EDG FTLR

\begin{tabular}{|c|c|c|c|c|c|c|c|c|}
\hline \multirow[b]{2}{*}{ Year } & \multirow[b]{2}{*}{ Failures } & \multirow[b]{2}{*}{ Demands } & \multicolumn{3}{|c|}{ Regression Curve Data Points } & \multicolumn{3}{|c|}{ Plot Trend Error Bar Points } \\
\hline & & & Mean & $\begin{array}{c}\text { Lower } \\
(5 \%)\end{array}$ & $\begin{array}{l}\text { Upper } \\
(95 \%)\end{array}$ & $\begin{array}{c}\text { Lower } \\
(5 \%)\end{array}$ & $\begin{array}{l}\text { Upper } \\
(95 \%)\end{array}$ & Mean \\
\hline \multicolumn{2}{|c|}{2015 Update } & & & & & 4.25E-04 & 2.16E-03 & 1.15E-03 \\
\hline 1998 & 0 & 106 & -- & -- & -- & 8.89E-06 & 1.76E-02 & $2.26 \mathrm{E}-03$ \\
\hline 1999 & 1 & 131 & -- & -- & -- & 7.16E-04 & $2.23 \mathrm{E}-02$ & $6.10 \mathrm{E}-03$ \\
\hline 2000 & 0 & 121 & -- & -- & -- & 8.33E-06 & 1.64E-02 & $2.12 \mathrm{E}-03$ \\
\hline 2001 & 0 & 125 & -- & -- & -- & 8.17E-06 & $1.61 \mathrm{E}-02$ & 2.08E-03 \\
\hline 2002 & 1 & 124 & -- & -- & -- & 7.35E-04 & 2.29E-02 & 6.27E-03 \\
\hline 2003 & 0 & 129 & -- & -- & -- & 8.06E-06 & 1.59E-02 & $2.05 \mathrm{E}-03$ \\
\hline 2004 & 1 & 129 & -- & -- & -- & 7.20E-04 & $2.25 \mathrm{E}-02$ & $6.14 \mathrm{E}-03$ \\
\hline 2005 & 0 & 119 & -- & -- & -- & 8.38E-06 & 1.65E-02 & $2.13 \mathrm{E}-03$ \\
\hline 2006 & 0 & 124 & -- & -- & -- & 8.20E-06 & 1.62E-02 & 2.09E-03 \\
\hline 2007 & 0 & 117 & -- & -- & -- & 8.45E-06 & 1.67E-02 & $2.15 \mathrm{E}-03$ \\
\hline 2008 & 0 & 139 & -- & -- & -- & 7.72E-06 & $1.53 \mathrm{E}-02$ & 1.96E-03 \\
\hline 2009 & 0 & 118 & $3.28 \mathrm{E}-03$ & 1.32E-03 & 8.12E-03 & 8.42E-06 & 1.66E-02 & $2.14 \mathrm{E}-03$ \\
\hline 2010 & 1 & 132 & 3.34E-03 & 1.55E-03 & 7.22E-03 & 7.12E-04 & 2.22E-02 & 6.07E-03 \\
\hline 2011 & 0 & 137 & $3.41 \mathrm{E}-03$ & 1.78E-03 & 6.52E-03 & 7.79E-06 & 1.54E-02 & 1.98E-03 \\
\hline 2012 & 1 & 117 & $3.48 \mathrm{E}-03$ & 2.00E-03 & 6.04E-03 & 7.58E-04 & 2.36E-02 & 6.46E-03 \\
\hline 2013 & 0 & 137 & $3.55 \mathrm{E}-03$ & 2.16E-03 & 5.83E-03 & 7.79E-06 & 1.54E-02 & 1.98E-03 \\
\hline 2014 & 1 & 118 & $3.62 \mathrm{E}-03$ & 2.20E-03 & 5.96E-03 & 7.55E-04 & 2.35E-02 & $6.43 E-03$ \\
\hline 2015 & 1 & 127 & 3.70E-03 & 2.12E-03 & 6.42E-03 & 7.27E-04 & 2.27E-02 & 6.19E-03 \\
\hline 2016 & 0 & 126 & 3.77E-03 & 1.97E-03 & 7.22E-03 & 8.14E-06 & 1.61E-02 & 2.07E-03 \\
\hline 2017 & 0 & 125 & 3.85E-03 & 1.77E-03 & 8.32E-03 & 8.18E-06 & 1.62E-02 & $2.08 \mathrm{E}-03$ \\
\hline 2018 & 1 & 129 & 3.93E-03 & 1.58E-03 & 9.74E-03 & 7.21E-04 & 2.25E-02 & $6.14 \mathrm{E}-03$ \\
\hline Total & 8 & 2,630 & & & & & & \\
\hline
\end{tabular}


Table 21. Plot data for Figure 6, failure rate estimate trend for HPCS EDG FTR $>1 \mathrm{H}$

\begin{tabular}{|c|c|c|c|c|c|c|c|c|}
\hline \multirow[b]{2}{*}{ Year } & \multirow[b]{2}{*}{ Failures } & \multirow[b]{2}{*}{$\begin{array}{c}\text { Run Time } \\
\text { (hr) }\end{array}$} & \multicolumn{3}{|c|}{ Regression Curve Data Points } & \multicolumn{3}{|c|}{ Plot Trend Error Bar Points } \\
\hline & & & Mean & $\begin{array}{l}\text { Lower } \\
(5 \%)\end{array}$ & $\begin{array}{l}\text { Upper } \\
(95 \%)\end{array}$ & $\begin{array}{l}\text { Lower } \\
(5 \%)\end{array}$ & $\begin{array}{l}\text { Upper } \\
(95 \%)\end{array}$ & Mean \\
\hline \multicolumn{2}{|c|}{2015 Update } & & & & & 4.25E-04 & 2.16E-03 & 1.15E-03 \\
\hline 1998 & 0 & 296 & -- & -- & -- & 3.65E-06 & 7.26E-03 & 9.29E-04 \\
\hline 1999 & 1 & 459 & -- & -- & -- & 2.51E-04 & 7.89E-03 & 2.14E-03 \\
\hline 2000 & 0 & 348 & -- & -- & -- & 3.33E-06 & $6.62 E-03$ & 8.47E-04 \\
\hline 2001 & 0 & 361 & -- & -- & -- & $3.26 \mathrm{E}-06$ & $6.48 \mathrm{E}-03$ & $8.29 \mathrm{E}-04$ \\
\hline 2002 & 0 & 327 & -- & -- & -- & $3.45 \mathrm{E}-06$ & 6.86E-03 & 8.77E-04 \\
\hline 2003 & 0 & 391 & -- & -- & -- & 3.11E-06 & 6.17E-03 & 7.90E-04 \\
\hline 2004 & 0 & 331 & -- & -- & -- & 3.43E-06 & 6.81E-03 & 8.71E-04 \\
\hline 2005 & 1 & 376 & -- & -- & -- & 2.84E-04 & 8.94E-03 & $2.42 \mathrm{E}-03$ \\
\hline 2006 & 0 & 379 & -- & -- & -- & 3.16E-06 & $6.29 \mathrm{E}-03$ & 8.05E-04 \\
\hline 2007 & 0 & 307 & -- & -- & -- & $3.58 \mathrm{E}-06$ & 7.11E-03 & $9.10 \mathrm{E}-04$ \\
\hline 2008 & 0 & 452 & -- & -- & -- & 2.83E-06 & 5.62E-03 & 7.20E-04 \\
\hline 2009 & 0 & 381 & 9.69E-04 & 3.93E-04 & 2.39E-03 & 3.15E-06 & 6.27E-03 & 8.02E-04 \\
\hline 2010 & 1 & 392 & 1.09E-03 & 5.06E-04 & 2.34E-03 & 2.77E-04 & $8.72 \mathrm{E}-03$ & 2.36E-03 \\
\hline 2011 & 0 & 425 & 1.22E-03 & 6.41E-04 & 2.32E-03 & 2.95E-06 & 5.86E-03 & 7.50E-04 \\
\hline 2012 & 0 & 162 & 1.37E-03 & 7.92E-04 & 2.36E-03 & 4.87E-06 & 9.67E-03 & 1.24E-03 \\
\hline 2013 & 1 & 298 & 1.53E-03 & 9.38E-04 & 2.51E-03 & $3.25 \mathrm{E}-04$ & 1.02E-02 & $2.78 \mathrm{E}-03$ \\
\hline 2014 & 0 & 194 & 1.72E-03 & 1.05E-03 & 2.82E-03 & 4.51E-06 & 8.96E-03 & 1.15E-03 \\
\hline 2015 & 0 & 228 & 1.93E-03 & 1.11E-03 & 3.35E-03 & 4.18E-06 & 8.30E-03 & 1.06E-03 \\
\hline 2016 & 1 & 205 & 2.17E-03 & 1.13E-03 & 4.15E-03 & 3.93E-04 & 1.24E-02 & 3.35E-03 \\
\hline 2017 & 0 & 195 & 2.43E-03 & 1.12E-03 & 5.27E-03 & 4.50E-06 & 8.94E-03 & 1.14E-03 \\
\hline 2018 & 2 & 186 & 2.73E-03 & 1.09E-03 & 6.79E-03 & 1.34E-03 & 1.64E-02 & 5.83E-03 \\
\hline Total & 7 & 6,694 & & & & & & \\
\hline
\end{tabular}


Table 22. Plot data for Figure 7, EPS EDG UA trend

\begin{tabular}{|c|c|c|c|c|c|c|c|c|}
\hline \multirow[b]{2}{*}{ Year } & \multirow[b]{2}{*}{ UA Hours } & \multirow[b]{2}{*}{$\begin{array}{l}\text { Critical } \\
\text { Hours }\end{array}$} & \multicolumn{3}{|c|}{ Regression Curve Data Points } & \multicolumn{3}{|c|}{ Plot Trend Error Bar Points } \\
\hline & & & Mean & $\begin{array}{l}\text { Lower } \\
(5 \%)\end{array}$ & $\begin{array}{l}\text { Upper } \\
(95 \%)\end{array}$ & $\begin{array}{l}\text { Lower } \\
(5 \%)\end{array}$ & $\begin{array}{l}\text { Upper } \\
(95 \%)\end{array}$ & Mean \\
\hline \multicolumn{3}{|c|}{2015 Update } & & & & 4.44E-03 & $2.52 \mathrm{E}-02$ & $1.48 \mathrm{E}-02$ \\
\hline 1998 & 21,235 & $1,874,166$ & -- & -- & -- & 2.01E-03 & 2.42E-02 & 1.04E-02 \\
\hline 1999 & 22,769 & $2,005,223$ & -- & -- & -- & 2.55E-03 & $2.42 E-02$ & 1.10E-02 \\
\hline 2000 & 18,409 & $2,042,467$ & -- & -- & -- & 2.27E-03 & 2.08E-02 & $9.53 \mathrm{E}-03$ \\
\hline 2001 & 19,233 & $2,075,373$ & -- & -- & -- & $1.54 \mathrm{E}-03$ & 2.36E-02 & $9.72 \mathrm{E}-03$ \\
\hline 2002 & 24,631 & $2,093,196$ & -- & -- & -- & 2.31E-03 & 2.78E-02 & 1.20E-02 \\
\hline 2003 & 28,961 & $2,047,203$ & -- & -- & -- & 1.91E-03 & 3.49E-02 & 1.39E-02 \\
\hline 2004 & 29,617 & $2,099,392$ & -- & -- & -- & 1.24E-03 & 3.71E-02 & 1.36E-02 \\
\hline 2005 & 26,350 & $2,070,016$ & -- & -- & -- & 2.81E-03 & 2.90E-02 & $1.29 \mathrm{E}-02$ \\
\hline 2006 & 28,713 & $2,083,212$ & -- & -- & -- & 1.73E-03 & 3.36E-02 & 1.33E-02 \\
\hline 2007 & 34,106 & $2,104,023$ & -- & -- & -- & 2.41E-03 & 3.99E-02 & 1.62E-02 \\
\hline 2008 & 31,755 & $2,089,978$ & -- & -- & -- & 2.87E-03 & 3.53E-02 & 1.52E-02 \\
\hline 2009 & 33,204 & $2,059,429$ & 1.60E-02 & $1.45 \mathrm{E}-02$ & 1.76E-02 & 2.86E-03 & 3.79E-02 & 1.61E-02 \\
\hline 2010 & 30,037 & $2,081,690$ & 1.58E-02 & 1.46E-02 & 1.70E-02 & 3.32E-03 & 3.16E-02 & 1.44E-02 \\
\hline 2011 & 36,401 & $2,023,478$ & $1.56 \mathrm{E}-02$ & 1.47E-02 & 1.64E-02 & 2.95E-03 & 4.18E-02 & 1.75E-02 \\
\hline 2012 & 32,470 & $1,977,596$ & $1.53 \mathrm{E}-02$ & 1.48E-02 & 1.58E-02 & 3.02E-03 & 3.68E-02 & 1.59E-02 \\
\hline 2013 & 30,642 & $2,007,371$ & $1.51 \mathrm{E}-02$ & 1.49E-02 & 1.53E-02 & 2.29E-03 & 3.34E-02 & $1.39 \mathrm{E}-02$ \\
\hline 2014 & 28,292 & $2,027,147$ & 1.49E-02 & 1.47E-02 & $1.50 \mathrm{E}-02$ & 3.15E-03 & 3.19E-02 & 1.43E-02 \\
\hline 2015 & 30,706 & $2,008,809$ & 1.46E-02 & 1.42E-02 & 1.51E-02 & 3.65E-03 & 3.36E-02 & $1.54 \mathrm{E}-02$ \\
\hline 2016 & 29,859 & $2,025,233$ & $1.44 \mathrm{E}-02$ & 1.37E-02 & $1.52 \mathrm{E}-02$ & 2.95E-04 & 5.06E-02 & $1.51 \mathrm{E}-02$ \\
\hline 2017 & 30,463 & $1,997,343$ & 1.42E-02 & 1.32E-02 & 1.53E-02 & 2.00E-03 & 3.69E-02 & 1.47E-02 \\
\hline 2018 & 25,907 & $1,990,438$ & 1.40E-02 & 1.27E-02 & 1.54E-02 & 2.88E-03 & 2.93E-02 & 1.31E-02 \\
\hline Total & 593,761 & $42,782,783$ & & & & & & \\
\hline
\end{tabular}


Table 23. Plot data for Figure 8, HPCS EDG UA trend

\begin{tabular}{|c|c|c|c|c|c|c|c|c|}
\hline \multirow[b]{2}{*}{ Year } & \multirow[b]{2}{*}{ UA Hours } & \multirow[b]{2}{*}{$\begin{array}{l}\text { Critical } \\
\text { Hours }\end{array}$} & \multicolumn{3}{|c|}{ Regression Curve Data Points } & \multicolumn{3}{|c|}{ Plot Trend Error Bar Points } \\
\hline & & & Mean & $\begin{array}{l}\text { Lower } \\
(5 \%)\end{array}$ & $\begin{array}{l}\text { Upper } \\
(95 \%)\end{array}$ & $\begin{array}{l}\text { Lower } \\
(5 \%)\end{array}$ & $\begin{array}{l}\text { Upper } \\
(95 \%)\end{array}$ & Mean \\
\hline \multicolumn{2}{|c|}{2015 Update } & & & & & 7.59E-03 & 1.58E-02 & 1.17E-02 \\
\hline 1998 & 255 & 42,029 & -- & -- & -- & 4.24E-04 & 1.15E-02 & 4.27E-03 \\
\hline 1999 & 760 & 55,565 & -- & -- & -- & 7.09E-04 & 3.99E-02 & $1.35 \mathrm{E}-02$ \\
\hline 2000 & 959 & 65,705 & -- & -- & -- & 8.40E-04 & 4.33E-02 & $1.48 \mathrm{E}-02$ \\
\hline 2001 & 474 & 65,093 & -- & -- & -- & 1.27E-03 & 1.69E-02 & 7.13E-03 \\
\hline 2002 & 431 & 65,329 & -- & -- & -- & 1.14E-03 & 1.59E-02 & 6.66E-03 \\
\hline 2003 & 825 & 65,040 & -- & -- & -- & 6.07E-03 & 2.11E-02 & 1.26E-02 \\
\hline 2004 & 855 & 65,589 & -- & -- & -- & 4.00E-03 & 2.63E-02 & 1.31E-02 \\
\hline 2005 & 610 & 64,383 & -- & -- & -- & 3.59E-03 & 1.75E-02 & $9.42 \mathrm{E}-03$ \\
\hline 2006 & 453 & 66,949 & -- & -- & -- & 1.85E-03 & 1.40E-02 & 6.71E-03 \\
\hline 2007 & 592 & 64,512 & -- & -- & -- & 1.92E-03 & 2.07E-02 & $9.14 \mathrm{E}-03$ \\
\hline 2008 & 861 & 65,262 & -- & -- & -- & 2.31E-03 & 3.24E-02 & 1.36E-02 \\
\hline 2009 & 519 & 63,966 & 1.16E-02 & 7.37E-03 & 1.58E-02 & 2.54E-03 & 1.63E-02 & 8.13E-03 \\
\hline 2010 & 1,050 & 67,158 & 1.21E-02 & 8.83E-03 & 1.54E-02 & 2.34E-03 & 3.80E-02 & $1.55 \mathrm{E}-02$ \\
\hline 2011 & 991 & 62,329 & 1.26E-02 & 1.03E-02 & 1.50E-02 & 4.37E-03 & 3.29E-02 & $1.58 \mathrm{E}-02$ \\
\hline 2012 & 815 & 64,557 & 1.32E-02 & 1.17E-02 & 1.46E-02 & $2.20 \mathrm{E}-03$ & 2.92E-02 & $1.24 \mathrm{E}-02$ \\
\hline 2013 & 952 & 64,142 & 1.37E-02 & 1.32E-02 & 1.41E-02 & 2.33E-03 & 3.51E-02 & $1.45 \mathrm{E}-02$ \\
\hline 2014 & 1,012 & 66,677 & 1.42E-02 & 1.37E-02 & 1.47E-02 & 2.39E-03 & 3.66E-02 & 1.51E-02 \\
\hline 2015 & 627 & 65,277 & 1.47E-02 & 1.33E-02 & 1.61E-02 & 1.40E-03 & 2.37E-02 & 9.56E-03 \\
\hline 2016 & 884 & 62,704 & 1.52E-02 & 1.29E-02 & 1.76E-02 & 3.09E-03 & 3.03E-02 & 1.37E-02 \\
\hline 2017 & 827 & 63,353 & 1.58E-02 & 1.25E-02 & 1.90E-02 & 1.76E-03 & 3.45E-02 & 1.36E-02 \\
\hline 2018 & 1,346 & 64,262 & 1.63E-02 & 1.21E-02 & 2.05E-02 & 1.46E-03 & 6.04E-02 & 2.12E-02 \\
\hline Total & 16,097 & $1,329,882$ & & & & & & \\
\hline
\end{tabular}


Table 24. Plot data for Figure 9, EPS EDG unreliability trend (8-hour mission)

\begin{tabular}{|c|c|c|c|c|c|c|}
\hline \multirow[b]{2}{*}{ Year } & \multicolumn{3}{|c|}{ Regression Curve Data Points } & \multicolumn{3}{|c|}{ Plot Trend Error Bar Points } \\
\hline & Mean & Lower (5\%) & Upper (95\%) & Lower (5\%) & $\begin{array}{l}\text { Upper } \\
(95 \%)\end{array}$ & Mean \\
\hline 1998 & -- & -- & -- & $1.22 \mathrm{E}-02$ & 3.54E-02 & $2.11 \mathrm{E}-02$ \\
\hline 1999 & -- & -- & -- & 6.16E-03 & 2.93E-02 & 1.49E-02 \\
\hline 2000 & -- & -- & -- & 1.16E-02 & 3.45E-02 & $2.08 \mathrm{E}-02$ \\
\hline 2001 & -- & -- & -- & 9.85E-03 & $3.18 \mathrm{E}-02$ & 1.87E-02 \\
\hline 2002 & -- & -- & -- & 1.15E-02 & 3.04E-02 & 1.94E-02 \\
\hline 2003 & -- & -- & -- & $1.48 \mathrm{E}-02$ & $3.62 E-02$ & 2.37E-02 \\
\hline 2004 & -- & -- & -- & $1.41 \mathrm{E}-02$ & 3.72E-02 & 2.30E-02 \\
\hline 2005 & -- & -- & -- & 1.56E-02 & 3.74E-02 & $2.45 \mathrm{E}-02$ \\
\hline 2006 & -- & -- & -- & 1.10E-02 & 3.68E-02 & 2.09E-02 \\
\hline 2007 & -- & -- & -- & 1.93E-02 & 4.50E-02 & 2.99E-02 \\
\hline 2008 & -- & -- & -- & 1.87E-02 & 5.30E-02 & 3.17E-02 \\
\hline 2009 & 2.97E-02 & $2.55 \mathrm{E}-02$ & 3.47E-02 & 1.39E-02 & 4.99E-02 & 2.71E-02 \\
\hline 2010 & 3.02E-02 & 2.65E-02 & $3.45 \mathrm{E}-02$ & $1.51 \mathrm{E}-02$ & 5.34E-02 & 2.88E-02 \\
\hline 2011 & 3.07E-02 & $2.75 \mathrm{E}-02$ & 3.43E-02 & 2.05E-02 & 5.99E-02 & 3.46E-02 \\
\hline 2012 & 3.12E-02 & 2.84E-02 & 3.43E-02 & 1.95E-02 & 4.93E-02 & 3.15E-02 \\
\hline 2013 & 3.18E-02 & 2.92E-02 & 3.46E-02 & 1.95E-02 & 4.86E-02 & $3.20 \mathrm{E}-02$ \\
\hline 2014 & 3.23E-02 & 2.97E-02 & 3.51E-02 & 2.16E-02 & 5.56E-02 & 3.55E-02 \\
\hline 2015 & 3.28E-02 & 2.99E-02 & 3.61E-02 & 1.73E-02 & 5.16E-02 & 3.09E-02 \\
\hline 2016 & 3.34E-02 & 2.99E-02 & 3.73E-02 & 1.65E-02 & 5.33E-02 & $3.11 \mathrm{E}-02$ \\
\hline 2017 & 3.39E-02 & 2.97E-02 & 3.87E-02 & 2.53E-02 & 6.66E-02 & 4.21E-02 \\
\hline 2018 & $3.45 \mathrm{E}-02$ & 2.95E-02 & 4.03E-02 & 1.57E-02 & 4.84E-02 & 2.89E-02 \\
\hline
\end{tabular}


Table 25. Plot data for Figure 10, HPCS EDG unreliability trend (8-hour mission)

\begin{tabular}{ccccccc}
\hline & \multicolumn{2}{c}{ Regression Curve Data Points } & \multicolumn{3}{c}{ Plot Trend Error Bar Points } \\
\cline { 2 - 6 } Year & Mean & Lower (5\%) & Upper (95\%) & Lower (5\%) & Upper \\
(95\%) & Mean \\
\hline 1998 & -- & -- & -- & $2.88 \mathrm{E}-03$ & $2.79 \mathrm{E}-02$ & $1.20 \mathrm{E}-02$ \\
1999 & -- & -- & -- & $9.87 \mathrm{E}-03$ & $4.38 \mathrm{E}-02$ & $2.42 \mathrm{E}-02$ \\
\hline 2000 & -- & -- & -- & $4.03 \mathrm{E}-03$ & $5.25 \mathrm{E}-02$ & $2.15 \mathrm{E}-02$ \\
\hline 2001 & -- & -- & -- & $3.79 \mathrm{E}-03$ & $4.87 \mathrm{E}-02$ & $2.09 \mathrm{E}-02$ \\
\hline 2002 & -- & -- & -- & $6.50 \mathrm{E}-03$ & $6.06 \mathrm{E}-02$ & $2.62 \mathrm{E}-02$ \\
2003 & -- & -- & -- & $4.53 \mathrm{E}-03$ & $5.36 \mathrm{E}-02$ & $2.27 \mathrm{E}-02$ \\
\hline 2004 & -- & -- & -- & $6.34 \mathrm{E}-03$ & $3.50 \mathrm{E}-02$ & $1.81 \mathrm{E}-02$ \\
\hline 2005 & -- & -- & -- & $8.45 \mathrm{E}-03$ & $4.28 \mathrm{E}-02$ & $2.25 \mathrm{E}-02$ \\
\hline 2006 & -- & -- & -- & $3.88 \mathrm{E}-03$ & $2.98 \mathrm{E}-02$ & $1.38 \mathrm{E}-02$ \\
\hline 2007 & -- & -- & -- & $4.04 \mathrm{E}-03$ & $3.01 \mathrm{E}-02$ & $1.41 \mathrm{E}-02$ \\
\hline 2008 & -- & -- & -- & $1.06 \mathrm{E}-02$ & $3.55 \mathrm{E}-02$ & $2.11 \mathrm{E}-02$ \\
\hline 2009 & $2.07 \mathrm{E}-02$ & $1.38 \mathrm{E}-02$ & $3.11 \mathrm{E}-02$ & $9.47 \mathrm{E}-03$ & $3.36 \mathrm{E}-02$ & $1.95 \mathrm{E}-02$ \\
\hline 2010 & $2.14 \mathrm{E}-02$ & $1.51 \mathrm{E}-02$ & $3.02 \mathrm{E}-02$ & $1.34 \mathrm{E}-02$ & $5.41 \mathrm{E}-02$ & $3.14 \mathrm{E}-02$ \\
\hline 2011 & $2.21 \mathrm{E}-02$ & $1.65 \mathrm{E}-02$ & $2.95 \mathrm{E}-02$ & $7.67 \mathrm{E}-03$ & $3.70 \mathrm{E}-02$ & $1.95 \mathrm{E}-02$ \\
\hline 2012 & $2.28 \mathrm{E}-02$ & $1.78 \mathrm{E}-02$ & $2.91 \mathrm{E}-02$ & $9.17 \mathrm{E}-03$ & $4.20 \mathrm{E}-02$ & $2.19 \mathrm{E}-02$ \\
\hline 2013 & $2.35 \mathrm{E}-02$ & $1.88 \mathrm{E}-02$ & $2.93 \mathrm{E}-02$ & $1.05 \mathrm{E}-02$ & $4.78 \mathrm{E}-02$ & $2.56 \mathrm{E}-02$ \\
\hline 2014 & $2.42 \mathrm{E}-02$ & $1.94 \mathrm{E}-02$ & $3.03 \mathrm{E}-02$ & $8.95 \mathrm{E}-03$ & $3.79 \mathrm{E}-02$ & $2.06 \mathrm{E}-02$ \\
\hline 2015 & $2.50 \mathrm{E}-02$ & $1.95 \mathrm{E}-02$ & $3.20 \mathrm{E}-02$ & $6.56 \mathrm{E}-03$ & $3.62 \mathrm{E}-02$ & $1.81 \mathrm{E}-02$ \\
\hline 2016 & $2.58 \mathrm{E}-02$ & $1.93 \mathrm{E}-02$ & $3.45 \mathrm{E}-02$ & $9.80 \mathrm{E}-03$ & $5.79 \mathrm{E}-02$ & $2.86 \mathrm{E}-02$ \\
\hline 2017 & $2.66 \mathrm{E}-02$ & $1.89 \mathrm{E}-02$ & $3.76 \mathrm{E}-02$ & $5.29 \mathrm{E}-03$ & $3.62 \mathrm{E}-02$ & $1.73 \mathrm{E}-02$ \\
\hline 2018 & $2.75 \mathrm{E}-02$ & $1.83 \mathrm{E}-02$ & $4.13 \mathrm{E}-02$ & $2.12 \mathrm{E}-02$ & $8.53 \mathrm{E}-02$ & $4.87 \mathrm{E}-02$ \\
\hline
\end{tabular}


Table 26. Plot data for Figure 11, frequency of start demands (demands per reactor year) trend for EPS and HPCS EDGS

\begin{tabular}{|c|c|c|c|c|c|c|c|c|}
\hline \multirow[b]{2}{*}{ Year } & \multirow[b]{2}{*}{ Demands } & \multirow[b]{2}{*}{$\begin{array}{c}\text { Reactor } \\
\text { Years }\end{array}$} & \multicolumn{3}{|c|}{ Regression Curve Data Points } & \multicolumn{3}{|c|}{ Plot Trend Error Bar Points } \\
\hline & & & Mean & $\begin{array}{l}\text { Lower } \\
(5 \%)\end{array}$ & $\begin{array}{l}\text { Upper } \\
(95 \%)\end{array}$ & $\begin{array}{l}\text { Lower } \\
(5 \%)\end{array}$ & $\begin{array}{l}\text { Upper } \\
(95 \%)\end{array}$ & Mean \\
\hline 1998 & 4,436 & 95.0 & -- & -- & -- & $4.55 E+01$ & $4.79 E+01$ & $4.67 \mathrm{E}+01$ \\
\hline 1999 & 4,355 & 95.0 & -- & -- & -- & 4.47E+01 & 4.70E+01 & $4.58 \mathrm{E}+01$ \\
\hline 2000 & 4,054 & 95.3 & -- & -- & -- & 4.15E+01 & 4.37E+01 & $4.26 \mathrm{E}+01$ \\
\hline 2001 & 4,177 & 95.0 & -- & -- & -- & $4.29 E+01$ & $4.51 E+01$ & $4.40 E+01$ \\
\hline 2002 & 4,412 & 95.0 & -- & -- & -- & $4.53 E+01$ & 4.76E+01 & $4.64 \mathrm{E}+01$ \\
\hline 2003 & 4,481 & 95.0 & -- & -- & -- & $4.60 E+01$ & $4.83 E+01$ & $4.72 E+01$ \\
\hline 2004 & 4,477 & 95.3 & -- & -- & -- & $4.58 \mathrm{E}+01$ & $4.82 E+01$ & $4.70 E+01$ \\
\hline 2005 & 4,516 & 95.0 & -- & -- & -- & $4.64 E+01$ & $4.87 E+01$ & $4.75 E+01$ \\
\hline 2006 & 4,508 & 95.0 & -- & -- & -- & $4.63 E+01$ & $4.86 E+01$ & $4.75 E+01$ \\
\hline 2007 & 4,413 & 95.0 & -- & -- & -- & $4.53 E+01$ & $4.76 E+01$ & $4.65 E+01$ \\
\hline 2008 & 4,483 & 95.3 & -- & -- & -- & $4.59 E+01$ & $4.82 E+01$ & $4.71 E+01$ \\
\hline 2009 & 4,362 & 95.0 & $4.49 E+01$ & 4.37E+01 & $4.61 \mathrm{E}+01$ & $4.48 \mathrm{E}+01$ & $4.71 E+01$ & $4.59 E+01$ \\
\hline 2010 & 4,242 & 95.0 & $4.51 \mathrm{E}+01$ & $4.41 \mathrm{E}+01$ & $4.61 \mathrm{E}+01$ & $4.35 E+01$ & $4.58 \mathrm{E}+01$ & $4.47 E+01$ \\
\hline 2011 & 4,279 & 95.0 & $4.52 E+01$ & $4.44 \mathrm{E}+01$ & $4.61 \mathrm{E}+01$ & $4.39 E+01$ & $4.62 E+01$ & $4.50 \mathrm{E}+01$ \\
\hline 2012 & 4,162 & 95.3 & $4.54 \mathrm{E}+01$ & 4.47E+01 & $4.61 \mathrm{E}+01$ & $4.26 \mathrm{E}+01$ & $4.48 E+01$ & $4.37 E+01$ \\
\hline 2013 & 4,261 & 92.6 & $4.56 \mathrm{E}+01$ & $4.49 \mathrm{E}+01$ & $4.62 \mathrm{E}+01$ & $4.49 E+01$ & $4.72 \mathrm{E}+01$ & $4.60 \mathrm{E}+01$ \\
\hline 2014 & 4,217 & 91.0 & $4.58 E+01$ & $4.51 \mathrm{E}+01$ & $4.64 \mathrm{E}+01$ & $4.52 E+01$ & $4.75 E+01$ & $4.63 E+01$ \\
\hline 2015 & 4,162 & 90.0 & $4.59 \mathrm{E}+01$ & $4.52 \mathrm{E}+01$ & $4.67 \mathrm{E}+01$ & $4.51 \mathrm{E}+01$ & $4.74 \mathrm{E}+01$ & $4.62 E+01$ \\
\hline 2016 & 4,177 & 90.0 & $4.61 \mathrm{E}+01$ & $4.53 E+01$ & $4.70 \mathrm{E}+01$ & $4.52 E+01$ & $4.76 \mathrm{E}+01$ & $4.64 \mathrm{E}+01$ \\
\hline 2017 & 4,126 & 89.0 & $4.63 E+01$ & $4.53 E+01$ & $4.73 E+01$ & $4.52 E+01$ & $4.76 \mathrm{E}+01$ & $4.64 \mathrm{E}+01$ \\
\hline 2018 & 4,100 & 88.7 & $4.65 E+01$ & $4.53 E+01$ & 4.77E+01 & $4.50 E+01$ & $4.74 \mathrm{E}+01$ & $4.62 E+01$ \\
\hline Total & 90,400 & $1,967.4$ & & & & & & \\
\hline
\end{tabular}


Table 27. Plot data for Figure 12, frequency of FTLR demands (demands per reactor year) trend for EPS and HPCS EDGs

\begin{tabular}{ccccccccc}
\hline & & & \multicolumn{2}{c}{ Regression Curve Data Points } & \multicolumn{2}{c}{ Plot Trend Error Bar Points } \\
\cline { 6 - 9 } Year & Demands & $\begin{array}{c}\text { Reactor } \\
\text { Years }\end{array}$ & Mean & $\begin{array}{c}\text { Lower } \\
\mathbf{( 5 \% )}\end{array}$ & $\begin{array}{c}\text { Upper } \\
\mathbf{( 9 5 \% )}\end{array}$ & $\begin{array}{c}\text { Lower } \\
\mathbf{( 5 \% )}\end{array}$ & $\begin{array}{c}\text { Upper } \\
\mathbf{( 9 5 \% )}\end{array}$ & Mean \\
\hline 1998 & 3,793 & 95.0 & -- & -- & -- & $3.89 \mathrm{E}+01$ & $4.10 \mathrm{E}+01$ & $3.99 \mathrm{E}+01$ \\
\hline 1999 & 3,778 & 95.0 & -- & -- & -- & $3.87 \mathrm{E}+01$ & $4.09 \mathrm{E}+01$ & $3.98 \mathrm{E}+01$ \\
\hline 2000 & 3,706 & 95.3 & -- & -- & -- & $3.79 \mathrm{E}+01$ & $4.00 \mathrm{E}+01$ & $3.89 \mathrm{E}+01$ \\
\hline 2001 & 3,840 & 95.0 & -- & -- & -- & $3.94 \mathrm{E}+01$ & $4.15 \mathrm{E}+01$ & $4.04 \mathrm{E}+01$ \\
\hline 2002 & 3,762 & 95.0 & -- & -- & -- & $3.85 \mathrm{E}+01$ & $4.07 \mathrm{E}+01$ & $3.96 \mathrm{E}+01$ \\
\hline 2003 & 3,919 & 95.0 & -- & -- & -- & $4.02 \mathrm{E}+01$ & $4.24 \mathrm{E}+01$ & $4.13 \mathrm{E}+01$ \\
\hline 2004 & 3,951 & 95.3 & -- & -- & -- & $4.04 \mathrm{E}+01$ & $4.26 \mathrm{E}+01$ & $4.15 \mathrm{E}+01$ \\
\hline 2005 & 3,903 & 95.0 & -- & -- & -- & $4.00 \mathrm{E}+01$ & $4.22 \mathrm{E}+01$ & $4.11 \mathrm{E}+01$ \\
\hline 2006 & 3,882 & 95.0 & -- & -- & -- & $3.98 \mathrm{E}+01$ & $4.20 \mathrm{E}+01$ & $4.09 \mathrm{E}+01$ \\
\hline 2007 & 3,762 & 95.0 & -- & -- & -- & $3.85 \mathrm{E}+01$ & $4.07 \mathrm{E}+01$ & $3.96 \mathrm{E}+01$ \\
\hline 2008 & 3,868 & 95.3 & -- & -- & -- & $3.95 \mathrm{E}+01$ & $4.17 \mathrm{E}+01$ & $4.06 \mathrm{E}+01$ \\
\hline 2009 & 3,786 & 95.0 & $3.92 \mathrm{E}+01$ & $3.84 \mathrm{E}+01$ & $4.00 \mathrm{E}+01$ & $3.88 \mathrm{E}+01$ & $4.09 \mathrm{E}+01$ & $3.99 \mathrm{E}+01$ \\
\hline 2010 & 3,704 & 95.0 & $3.94 \mathrm{E}+01$ & $3.87 \mathrm{E}+01$ & $4.01 \mathrm{E}+01$ & $3.79 \mathrm{E}+01$ & $4.01 \mathrm{E}+01$ & $3.90 \mathrm{E}+01$ \\
\hline 2011 & 3,742 & 95.0 & $3.96 \mathrm{E}+01$ & $3.90 \mathrm{E}+01$ & $4.02 \mathrm{E}+01$ & $3.83 \mathrm{E}+01$ & $4.05 \mathrm{E}+01$ & $3.94 \mathrm{E}+01$ \\
\hline 2012 & 3,686 & 95.3 & $3.97 \mathrm{E}+01$ & $3.92 \mathrm{E}+01$ & $4.03 \mathrm{E}+01$ & $3.76 \mathrm{E}+01$ & $3.98 \mathrm{E}+01$ & $3.87 \mathrm{E}+01$ \\
\hline 2013 & 3,714 & 92.6 & $3.99 \mathrm{E}+01$ & $3.95 \mathrm{E}+01$ & $4.04 \mathrm{E}+01$ & $3.90 \mathrm{E}+01$ & $4.12 \mathrm{E}+01$ & $4.01 \mathrm{E}+01$ \\
\hline 2014 & 3,721 & 91.0 & $4.01 \mathrm{E}+01$ & $3.97 \mathrm{E}+01$ & $4.06 \mathrm{E}+01$ & $3.98 \mathrm{E}+01$ & $4.20 \mathrm{E}+01$ & $4.09 \mathrm{E}+01$ \\
\hline 2015 & 3,661 & 90.0 & $4.03 \mathrm{E}+01$ & $3.98 \mathrm{E}+01$ & $4.08 \mathrm{E}+01$ & $3.96 \mathrm{E}+01$ & $4.18 \mathrm{E}+01$ & $4.07 \mathrm{E}+01$ \\
\hline 2016 & 3,653 & 90.0 & $4.05 \mathrm{E}+01$ & $3.99 \mathrm{E}+01$ & $4.11 \mathrm{E}+01$ & $3.95 \mathrm{E}+01$ & $4.17 \mathrm{E}+01$ & $4.06 \mathrm{E}+01$ \\
\hline 2017 & 3,609 & 89.0 & $4.07 \mathrm{E}+01$ & $4.00 \mathrm{E}+01$ & $4.14 \mathrm{E}+01$ & $3.94 \mathrm{E}+01$ & $4.17 \mathrm{E}+01$ & $4.05 \mathrm{E}+01$ \\
\hline 2018 & 3,613 & 88.7 & $4.09 \mathrm{E}+01$ & $4.00 \mathrm{E}+01$ & $4.18 \mathrm{E}+01$ & $3.96 \mathrm{E}+01$ & $4.18 \mathrm{E}+01$ & $4.07 \mathrm{E}+01$ \\
\hline Total & 79,052 & $1,967.4$ & & & & & & \\
\hline
\end{tabular}


Table 28. Plot data for Figure 13, frequency of run $>1$ H hours (hours per reactor year) trend for EPS and HPCS EDG

\begin{tabular}{|c|c|c|c|c|c|c|c|c|}
\hline \multirow[b]{2}{*}{ Year } & \multirow[b]{2}{*}{$\begin{array}{l}\text { Run } \\
\text { Hours }\end{array}$} & \multirow[b]{2}{*}{$\begin{array}{l}\text { Reactor } \\
\text { Years }\end{array}$} & \multicolumn{3}{|c|}{ Regression Curve Data Points } & \multicolumn{3}{|c|}{ Plot Trend Error Bar Points } \\
\hline & & & Mean & $\begin{array}{l}\text { Lower } \\
(5 \%)\end{array}$ & $\begin{array}{l}\text { Upper } \\
(95 \%)\end{array}$ & $\begin{array}{l}\text { Lower } \\
(5 \%)\end{array}$ & $\begin{array}{l}\text { Upper } \\
\text { (95\%) }\end{array}$ & Mean \\
\hline 1998 & 10,296 & 95.0 & -- & -- & -- & $1.07 \mathrm{E}+02$ & $1.10 \mathrm{E}+02$ & $1.08 \mathrm{E}+02$ \\
\hline 1999 & 10,779 & 95.0 & -- & -- & -- & $1.12 \mathrm{E}+02$ & $1.15 E+02$ & $1.13 E+02$ \\
\hline 2000 & 11,886 & 95.3 & -- & -- & -- & $1.23 \mathrm{E}+02$ & $1.27 \mathrm{E}+02$ & $1.25 \mathrm{E}+02$ \\
\hline 2001 & 12,338 & 95.0 & -- & -- & -- & $1.28 \mathrm{E}+02$ & $1.32 E+02$ & $1.30 \mathrm{E}+02$ \\
\hline 2002 & 12,668 & 95.0 & -- & -- & -- & $1.31 \mathrm{E}+02$ & $1.35 E+02$ & $1.33 \mathrm{E}+02$ \\
\hline 2003 & 12,090 & 95.0 & -- & -- & -- & $1.25 \mathrm{E}+02$ & $1.29 E+02$ & 1.27E+02 \\
\hline 2004 & 12,078 & 95.3 & -- & -- & -- & $1.25 \mathrm{E}+02$ & $1.29 \mathrm{E}+02$ & $1.27 \mathrm{E}+02$ \\
\hline 2005 & 12,683 & 95.0 & -- & -- & -- & $1.32 \mathrm{E}+02$ & $1.35 E+02$ & $1.34 \mathrm{E}+02$ \\
\hline 2006 & 11,748 & 95.0 & -- & -- & -- & $1.22 \mathrm{E}+02$ & $1.26 \mathrm{E}+02$ & $1.24 \mathrm{E}+02$ \\
\hline 2007 & 11,672 & 95.0 & -- & -- & -- & $1.21 \mathrm{E}+02$ & $1.25 E+02$ & $1.23 E+02$ \\
\hline 2008 & 11,690 & 95.3 & -- & -- & -- & $1.21 \mathrm{E}+02$ & $1.25 E+02$ & $1.23 E+02$ \\
\hline 2009 & 11,604 & 95.0 & $1.16 \mathrm{E}+02$ & $9.53 \mathrm{E}+01$ & $1.42 \mathrm{E}+02$ & $1.20 \mathrm{E}+02$ & $1.24 \mathrm{E}+02$ & $1.22 \mathrm{E}+02$ \\
\hline 2010 & 11,169 & 95.0 & $1.11 \mathrm{E}+02$ & $9.38 \mathrm{E}+01$ & $1.31 \mathrm{E}+02$ & $1.16 \mathrm{E}+02$ & $1.19 E+02$ & $1.18 \mathrm{E}+02$ \\
\hline 2011 & 12,234 & 95.0 & $1.06 \mathrm{E}+02$ & $9.19 E+01$ & $1.22 \mathrm{E}+02$ & $1.27 \mathrm{E}+02$ & $1.31 \mathrm{E}+02$ & $1.29 \mathrm{E}+02$ \\
\hline 2012 & 7,419 & 95.3 & $1.01 \mathrm{E}+02$ & $8.94 \mathrm{E}+01$ & 1.14E+02 & $7.64 \mathrm{E}+01$ & $7.94 \mathrm{E}+01$ & $7.79 \mathrm{E}+01$ \\
\hline 2013 & 8,094 & 92.6 & $9.64 \mathrm{E}+01$ & $8.59 E+01$ & $1.08 \mathrm{E}+02$ & $8.58 \mathrm{E}+01$ & $8.91 E+01$ & $8.74 \mathrm{E}+01$ \\
\hline 2014 & 7,327 & 91.0 & $9.19 E+01$ & $8.14 \mathrm{E}+01$ & $1.04 \mathrm{E}+02$ & $7.90 \mathrm{E}+01$ & $8.21 E+01$ & $8.05 E+01$ \\
\hline 2015 & 7,843 & 90.0 & $8.77 \mathrm{E}+01$ & $7.63 \mathrm{E}+01$ & $1.01 \mathrm{E}+02$ & $8.55 \mathrm{E}+01$ & $8.88 \mathrm{E}+01$ & $8.71 \mathrm{E}+01$ \\
\hline 2016 & 7,630 & 90.0 & $8.37 E+01$ & $7.09 E+01$ & $9.88 E+01$ & $8.32 E+01$ & $8.64 E+01$ & $8.48 E+01$ \\
\hline 2017 & 7,418 & 89.0 & $7.98 \mathrm{E}+01$ & $6.55 E+01$ & $9.72 \mathrm{E}+01$ & $8.18 \mathrm{E}+01$ & $8.50 E+01$ & $8.33 E+01$ \\
\hline 2018 & 7,856 & 88.7 & $7.62 \mathrm{E}+01$ & $6.04 \mathrm{E}+01$ & $9.60 \mathrm{E}+01$ & $8.69 \mathrm{E}+01$ & $9.02 E+01$ & $8.85 E+01$ \\
\hline Total & 218,522 & $1,967.4$ & & & & & & \\
\hline
\end{tabular}


Table 29. Plot data for Figure 14, frequency of FTS events (events per reactor year) trend for EPS and HPCS EDGs

\begin{tabular}{ccccccccc}
\hline & & & \multicolumn{2}{c}{ Regression Curve Data Points } & \multicolumn{2}{c}{ Plot Trend Error Bar Points } \\
\cline { 6 - 9 } Year & Failures & $\begin{array}{c}\text { Reactor } \\
\text { Years }\end{array}$ & Mean & $\begin{array}{c}\text { Lower } \\
\mathbf{( 5 \% )}\end{array}$ & $\begin{array}{c}\text { Upper } \\
\mathbf{( 9 5 \% )}\end{array}$ & $\begin{array}{c}\text { Lower } \\
\mathbf{( 5 \% )}\end{array}$ & $\begin{array}{c}\text { Upper } \\
\mathbf{( 9 5 \% )}\end{array}$ & Mean \\
\hline 1998 & 18 & 95.0 & -- & -- & -- & $1.22 \mathrm{E}-01$ & $2.77 \mathrm{E}-01$ & $1.88 \mathrm{E}-01$ \\
\hline 1999 & 9 & 95.0 & -- & -- & -- & $5.13 \mathrm{E}-02$ & $1.66 \mathrm{E}-01$ & $9.63 \mathrm{E}-02$ \\
\hline 2000 & 12 & 95.3 & -- & -- & -- & $7.39 \mathrm{E}-02$ & $2.03 \mathrm{E}-01$ & $1.26 \mathrm{E}-01$ \\
\hline 2001 & 12 & 95.0 & -- & -- & -- & $7.41 \mathrm{E}-02$ & $2.03 \mathrm{E}-01$ & $1.27 \mathrm{E}-01$ \\
\hline 2002 & 10 & 95.0 & -- & -- & -- & $5.88 \mathrm{E}-02$ & $1.78 \mathrm{E}-01$ & $1.06 \mathrm{E}-01$ \\
\hline 2003 & 17 & 95.0 & -- & -- & -- & $1.14 \mathrm{E}-01$ & $2.65 \mathrm{E}-01$ & $1.77 \mathrm{E}-01$ \\
\hline 2004 & 14 & 95.3 & -- & -- & -- & $8.95 \mathrm{E}-02$ & $2.27 \mathrm{E}-01$ & $1.47 \mathrm{E}-01$ \\
\hline 2005 & 16 & 95.0 & -- & -- & -- & $1.06 \mathrm{E}-01$ & $2.52 \mathrm{E}-01$ & $1.67 \mathrm{E}-01$ \\
\hline 2006 & 9 & 95.0 & -- & -- & -- & $5.13 \mathrm{E}-02$ & $1.66 \mathrm{E}-01$ & $9.63 \mathrm{E}-02$ \\
\hline 2007 & 11 & 95.0 & -- & -- & -- & $6.64 \mathrm{E}-02$ & $1.91 \mathrm{E}-01$ & $1.17 \mathrm{E}-01$ \\
\hline 2008 & 9 & 95.3 & -- & -- & -- & $5.11 \mathrm{E}-02$ & $1.65 \mathrm{E}-01$ & $9.61 \mathrm{E}-02$ \\
\hline 2009 & 15 & 95.0 & $1.63 \mathrm{E}-01$ & $1.10 \mathrm{E}-01$ & $2.43 \mathrm{E}-01$ & $9.77 \mathrm{E}-02$ & $2.40 \mathrm{E}-01$ & $1.57 \mathrm{E}-01$ \\
\hline 2010 & 15 & 95.0 & $1.56 \mathrm{E}-01$ & $1.11 \mathrm{E}-01$ & $2.17 \mathrm{E}-01$ & $9.77 \mathrm{E}-02$ & $2.40 \mathrm{E}-01$ & $1.57 \mathrm{E}-01$ \\
\hline 2011 & 19 & 95.0 & $1.48 \mathrm{E}-01$ & $1.12 \mathrm{E}-01$ & $1.96 \mathrm{E}-01$ & $1.30 \mathrm{E}-01$ & $2.89 \mathrm{E}-01$ & $1.98 \mathrm{E}-01$ \\
\hline 2012 & 14 & 95.3 & $1.41 \mathrm{E}-01$ & $1.11 \mathrm{E}-01$ & $1.80 \mathrm{E}-01$ & $8.95 \mathrm{E}-02$ & $2.27 \mathrm{E}-01$ & $1.47 \mathrm{E}-01$ \\
\hline 2013 & 6 & 92.6 & $1.34 \mathrm{E}-01$ & $1.07 \mathrm{E}-01$ & $1.69 \mathrm{E}-01$ & $3.06 \mathrm{E}-02$ & $1.30 \mathrm{E}-01$ & $6.76 \mathrm{E}-02$ \\
\hline 2014 & 13 & 91.0 & $1.28 \mathrm{E}-01$ & $1.01 \mathrm{E}-01$ & $1.63 \mathrm{E}-01$ & $8.53 \mathrm{E}-02$ & $2.25 \mathrm{E}-01$ & $1.43 \mathrm{E}-01$ \\
\hline 2015 & 13 & 90.0 & $1.22 \mathrm{E}-01$ & $9.24 \mathrm{E}-02$ & $1.60 \mathrm{E}-01$ & $8.62 \mathrm{E}-02$ & $2.27 \mathrm{E}-01$ & $1.44 \mathrm{E}-01$ \\
\hline 2016 & 13 & 90.0 & $1.16 \mathrm{E}-01$ & $8.35 \mathrm{E}-02$ & $1.61 \mathrm{E}-01$ & $8.62 \mathrm{E}-02$ & $2.27 \mathrm{E}-01$ & $1.44 \mathrm{E}-01$ \\
\hline 2017 & 10 & 89.0 & $1.10 \mathrm{E}-01$ & $7.48 \mathrm{E}-02$ & $1.63 \mathrm{E}-01$ & $6.26 \mathrm{E}-02$ & $1.90 \mathrm{E}-01$ & $1.13 \mathrm{E}-01$ \\
\hline 2018 & 8 & 88.7 & $1.05 \mathrm{E}-01$ & $6.66 \mathrm{E}-02$ & $1.66 \mathrm{E}-01$ & $4.69 \mathrm{E}-02$ & $1.63 \mathrm{E}-01$ & $9.20 \mathrm{E}-02$ \\
\hline Total & 263 & $1,967.4$ & & & & & & \\
\hline
\end{tabular}


Table 30. Plot data for Figure 15, frequency of FTLR events (events per reactor year) trend for EPS and HPCS EDGs

\begin{tabular}{ccccccccc}
\hline & & & \multicolumn{2}{c}{ Regression Curve Data Points } & \multicolumn{2}{c}{ Plot Trend Error Bar Points } \\
\cline { 6 - 9 } Year & Failures & $\begin{array}{c}\text { Reactor } \\
\text { Years }\end{array}$ & Mean & $\begin{array}{c}\text { Lower } \\
\mathbf{( 5 \% )}\end{array}$ & $\begin{array}{c}\text { Upper } \\
\mathbf{( 9 5 \% )}\end{array}$ & $\begin{array}{c}\text { Lower } \\
\mathbf{( 5 \% )}\end{array}$ & $\begin{array}{c}\text { Upper } \\
\mathbf{( 9 5 \% )}\end{array}$ & Mean \\
\hline 1998 & 14 & 95.0 & -- & -- & -- & $8.99 \mathrm{E}-02$ & $2.28 \mathrm{E}-01$ & $1.47 \mathrm{E}-01$ \\
\hline 1999 & 5 & 95.0 & -- & -- & -- & $2.32 \mathrm{E}-02$ & $1.14 \mathrm{E}-01$ & $5.59 \mathrm{E}-02$ \\
\hline 2000 & 8 & 95.3 & -- & -- & -- & $4.39 \mathrm{E}-02$ & $1.53 \mathrm{E}-01$ & $8.61 \mathrm{E}-02$ \\
\hline 2001 & 13 & 95.0 & -- & -- & -- & $8.20 \mathrm{E}-02$ & $2.16 \mathrm{E}-01$ & $1.37 \mathrm{E}-01$ \\
\hline 2002 & 14 & 95.0 & -- & -- & -- & $8.99 \mathrm{E}-02$ & $2.28 \mathrm{E}-01$ & $1.47 \mathrm{E}-01$ \\
\hline 2003 & 15 & 95.0 & -- & -- & -- & $9.79 \mathrm{E}-02$ & $2.41 \mathrm{E}-01$ & $1.57 \mathrm{E}-01$ \\
\hline 2004 & 10 & 95.3 & -- & -- & -- & $5.87 \mathrm{E}-02$ & $1.78 \mathrm{E}-01$ & $1.06 \mathrm{E}-01$ \\
\hline 2005 & 15 & 95.0 & -- & -- & -- & $9.79 \mathrm{E}-02$ & $2.41 \mathrm{E}-01$ & $1.57 \mathrm{E}-01$ \\
\hline 2006 & 15 & 95.0 & -- & -- & -- & $9.79 \mathrm{E}-02$ & $2.41 \mathrm{E}-01$ & $1.57 \mathrm{E}-01$ \\
\hline 2007 & 21 & 95.0 & -- & -- & -- & $1.47 \mathrm{E}-01$ & $3.13 \mathrm{E}-01$ & $2.18 \mathrm{E}-01$ \\
\hline 2008 & 16 & 95.3 & -- & -- & -- & $1.06 \mathrm{E}-01$ & $2.52 \mathrm{E}-01$ & $1.67 \mathrm{E}-01$ \\
\hline 2009 & 18 & 95.0 & $1.63 \mathrm{E}-01$ & $1.27 \mathrm{E}-01$ & $2.09 \mathrm{E}-01$ & $1.22 \mathrm{E}-01$ & $2.77 \mathrm{E}-01$ & $1.88 \mathrm{E}-01$ \\
\hline 2010 & 11 & 95.0 & $1.58 \mathrm{E}-01$ & $1.28 \mathrm{E}-01$ & $1.94 \mathrm{E}-01$ & $6.65 \mathrm{E}-02$ & $1.91 \mathrm{E}-01$ & $1.17 \mathrm{E}-01$ \\
\hline 2011 & 16 & 95.0 & $1.52 \mathrm{E}-01$ & $1.28 \mathrm{E}-01$ & $1.82 \mathrm{E}-01$ & $1.06 \mathrm{E}-01$ & $2.53 \mathrm{E}-01$ & $1.68 \mathrm{E}-01$ \\
\hline 2012 & 17 & 95.3 & $1.48 \mathrm{E}-01$ & $1.27 \mathrm{E}-01$ & $1.72 \mathrm{E}-01$ & $1.14 \mathrm{E}-01$ & $2.64 \mathrm{E}-01$ & $1.77 \mathrm{E}-01$ \\
\hline 2013 & 12 & 92.6 & $1.43 \mathrm{E}-01$ & $1.24 \mathrm{E}-01$ & $1.64 \mathrm{E}-01$ & $7.61 \mathrm{E}-02$ & $2.09 \mathrm{E}-01$ & $1.30 \mathrm{E}-01$ \\
\hline 2014 & 12 & 91.0 & $1.38 \mathrm{E}-01$ & $1.19 \mathrm{E}-01$ & $1.60 \mathrm{E}-01$ & $7.73 \mathrm{E}-02$ & $2.12 \mathrm{E}-01$ & $1.32 \mathrm{E}-01$ \\
\hline 2015 & 13 & 90.0 & $1.34 \mathrm{E}-01$ & $1.13 \mathrm{E}-01$ & $1.58 \mathrm{E}-01$ & $8.64 \mathrm{E}-02$ & $2.28 \mathrm{E}-01$ & $1.44 \mathrm{E}-01$ \\
\hline 2016 & 11 & 90.0 & $1.30 \mathrm{E}-01$ & $1.06 \mathrm{E}-01$ & $1.58 \mathrm{E}-01$ & $7.00 \mathrm{E}-02$ & $2.01 \mathrm{E}-01$ & $1.23 \mathrm{E}-01$ \\
\hline 2017 & 9 & 89.0 & $1.25 \mathrm{E}-01$ & $9.92 \mathrm{E}-02$ & $1.59 \mathrm{E}-01$ & $5.47 \mathrm{E}-02$ & $1.77 \mathrm{E}-01$ & $1.03 \mathrm{E}-01$ \\
\hline 2018 & 13 & 88.7 & $1.21 \mathrm{E}-01$ & $9.21 \mathrm{E}-02$ & $1.60 \mathrm{E}-01$ & $8.76 \mathrm{E}-02$ & $2.31 \mathrm{E}-01$ & $1.46 \mathrm{E}-01$ \\
\hline Total & 278 & $1,967.4$ & & & & & & \\
\hline
\end{tabular}


Table 31. Plot data for Figure 16, frequency of FTR $>1$ H events (events per reactor year) trend for EPS and HPCS EDGS

\begin{tabular}{ccccccccc}
\hline & & & \multicolumn{3}{c}{ Regression Curve Data Points } & \multicolumn{2}{c}{ Plot Trend Error Bar Points } \\
\cline { 6 - 9 } Year & Failures & $\begin{array}{c}\text { Reactor } \\
\text { Years }\end{array}$ & Mean & $\begin{array}{c}\text { Lower } \\
\mathbf{( 5 \% )}\end{array}$ & $\begin{array}{c}\text { Upper } \\
\mathbf{( 9 5 \% )}\end{array}$ & $\begin{array}{c}\text { Lower } \\
\mathbf{( 5 \% )}\end{array}$ & $\begin{array}{c}\text { Upper } \\
\mathbf{( 9 5 \% )}\end{array}$ & Mean \\
\hline 1998 & 4 & 95.0 & -- & -- & -- & $1.69 \mathrm{E}-02$ & $1.00 \mathrm{E}-01$ & $4.58 \mathrm{E}-02$ \\
\hline 1999 & 1 & 95.0 & -- & -- & -- & $1.79 \mathrm{E}-03$ & $5.63 \mathrm{E}-02$ & $1.53 \mathrm{E}-02$ \\
\hline 2000 & 7 & 95.3 & -- & -- & -- & $3.69 \mathrm{E}-02$ & $1.40 \mathrm{E}-01$ & $7.61 \mathrm{E}-02$ \\
\hline 2001 & 2 & 95.0 & -- & -- & -- & $5.83 \mathrm{E}-03$ & $7.16 \mathrm{E}-02$ & $2.54 \mathrm{E}-02$ \\
\hline 2002 & 7 & 95.0 & -- & -- & -- & $3.70 \mathrm{E}-02$ & $1.40 \mathrm{E}-01$ & $7.63 \mathrm{E}-02$ \\
\hline 2003 & 10 & 95.0 & -- & -- & -- & $5.90 \mathrm{E}-02$ & $1.79 \mathrm{E}-01$ & $1.07 \mathrm{E}-01$ \\
\hline 2004 & 13 & 95.3 & -- & -- & -- & $8.20 \mathrm{E}-02$ & $2.16 \mathrm{E}-01$ & $1.37 \mathrm{E}-01$ \\
\hline 2005 & 14 & 95.0 & -- & -- & -- & $9.01 \mathrm{E}-02$ & $2.29 \mathrm{E}-01$ & $1.48 \mathrm{E}-01$ \\
\hline 2006 & 4 & 95.0 & -- & -- & -- & $1.69 \mathrm{E}-02$ & $1.00 \mathrm{E}-01$ & $4.58 \mathrm{E}-02$ \\
\hline 2007 & 17 & 95.0 & -- & -- & -- & $1.14 \mathrm{E}-01$ & $2.66 \mathrm{E}-01$ & $1.78 \mathrm{E}-01$ \\
\hline 2008 & 20 & 95.3 & -- & -- & -- & $1.39 \mathrm{E}-01$ & $3.01 \mathrm{E}-01$ & $2.08 \mathrm{E}-01$ \\
\hline 2009 & 8 & 95.0 & $1.33 \mathrm{E}-01$ & $7.95 \mathrm{E}-02$ & $2.23 \mathrm{E}-01$ & $4.41 \mathrm{E}-02$ & $1.53 \mathrm{E}-01$ & $8.65 \mathrm{E}-02$ \\
\hline 2010 & 13 & 95.0 & $1.36 \mathrm{E}-01$ & $8.77 \mathrm{E}-02$ & $2.10 \mathrm{E}-01$ & $8.22 \mathrm{E}-02$ & $2.17 \mathrm{E}-01$ & $1.37 \mathrm{E}-01$ \\
\hline 2011 & 21 & 95.0 & $1.39 \mathrm{E}-01$ & $9.59 \mathrm{E}-02$ & $2.00 \mathrm{E}-01$ & $1.47 \mathrm{E}-01$ & $3.14 \mathrm{E}-01$ & $2.19 \mathrm{E}-01$ \\
\hline 2012 & 11 & 95.3 & $1.41 \mathrm{E}-01$ & $1.03 \mathrm{E}-01$ & $1.93 \mathrm{E}-01$ & $6.64 \mathrm{E}-02$ & $1.91 \mathrm{E}-01$ & $1.17 \mathrm{E}-01$ \\
\hline 2013 & 17 & 92.6 & $1.44 \mathrm{E}-01$ & $1.09 \mathrm{E}-01$ & $1.91 \mathrm{E}-01$ & $1.17 \mathrm{E}-01$ & $2.72 \mathrm{E}-01$ & $1.83 \mathrm{E}-01$ \\
\hline 2014 & 17 & 91.0 & $1.47 \mathrm{E}-01$ & $1.12 \mathrm{E}-01$ & $1.94 \mathrm{E}-01$ & $1.19 \mathrm{E}-01$ & $2.77 \mathrm{E}-01$ & $1.86 \mathrm{E}-01$ \\
\hline 2015 & 12 & 90.0 & $1.50 \mathrm{E}-01$ & $1.11 \mathrm{E}-01$ & $2.04 \mathrm{E}-01$ & $7.83 \mathrm{E}-02$ & $2.15 \mathrm{E}-01$ & $1.34 \mathrm{E}-01$ \\
\hline 2016 & 10 & 90.0 & $1.53 \mathrm{E}-01$ & $1.07 \mathrm{E}-01$ & $2.19 \mathrm{E}-01$ & $6.22 \mathrm{E}-02$ & $1.89 \mathrm{E}-01$ & $1.13 \mathrm{E}-01$ \\
\hline 2017 & 22 & 89.0 & $1.57 \mathrm{E}-01$ & $1.02 \mathrm{E}-01$ & $2.39 \mathrm{E}-01$ & $1.66 \mathrm{E}-01$ & $3.47 \mathrm{E}-01$ & $2.44 \mathrm{E}-01$ \\
\hline 2018 & 10 & 88.7 & $1.60 \mathrm{E}-01$ & $9.68 \mathrm{E}-02$ & $2.64 \mathrm{E}-01$ & $6.30 \mathrm{E}-02$ & $1.91 \mathrm{E}-01$ & $1.14 \mathrm{E}-01$ \\
\hline Total & 240 & $1,967.4$ & & & & & & \\
\hline
\end{tabular}




\section{REFERENCES}

[1] United States Nuclear Regulatory Commission, " Component Performance Study: Emergency Diesel Generators 1998-2006," December 2007. [Online]. Available: https://nrcoe.inl.gov/resultsdb/publicdocs/CompPerf/edg-2006.pdf.

[2] J. A. Schroeder, "Enhanced Component Performance Study: Emergency Diesel Generators 19982016," INL/LTD-17-44204, Idaho National laboratory, April 2018.

[3] C. D. Gentillion, "Overview and Reference Document for Operational Experience Results and Databases Trending," February 2016. [Online]. Available: https://nrcoe.inel.gov/resultsdb/publicdocs/Overview-and-Reference.pdf.

[4] J. C. Lane, "NRC Operating Experience (OpE) Programs," Office of Nuclear Regulatory Research, July 2015. [Online]. Available: http://pbadupws.nrc.gov/docs/ML1518/ML15189A345.pdf. [Accessed 2015].

[5] Nuclear Energy Institute, "Regulatory Assessment Performance Indicator Guideline," NEI 99-02, Revision 7, August 2013.

[6] United States Nuclear Regulatory Commission, "Component Reliability Data Sheets Update 2015," February 2017. [Online]. Available: http://nrcoe.inl.gov/resultsdb/publicdocs/AvgPerf/ComponentReliabilityDataSheets2015.pdf.

[7] S. A. Eide, T. E. Wierman, C. D. Gentillon, D. M. Rasmuson and C. L. Atwood, "Industry-Average Performance for Components and Initiating Events at U.S. Commercial Nuclear Power Plants," NUREG/CR-6928, U.S. Nuclear Regulatory Commission, February 2007.

[8] C. L. Atwood, etc., "Handbook of Parameter Estimation for Probabilistic Risk Assessment," NUREG/CR-6823, U.S. Nuclear Regulatory Commission, September 2003.

[9] Institute of Nuclear Power Operations, "INPO Consolidated Event System (ICES) Reporting Requirements and Standards," INPO 12-009, Revision 8, Institute of Nuclear Power Operations, November 2015. 